$$
\begin{aligned}
& \text { Universidade de São Paulo } \\
& \text { Faculdade de Medicina de Ribeirão Preto } \\
& \text { Departamento de Genética }
\end{aligned}
$$

\title{
Marcadores Genéticos de Ancestralidade em Comunidades Fundadas por Açorianos na Ilha de Santa Catarina
}

\section{Yara Costa Netto Muniz}

Orientador:Prof. Dr. Aguinaldo Luiz Simões

Ribeirão Preto 2008 


\author{
Universidade de São Paulo \\ Faculdade de Medicina de Ribeirão Preto \\ Departamento de Genética
}

\title{
Marcadores Genéticos de Ancestralidade em \\ Comunidades Fundadas por Açorianos na Ilha de Santa \\ Catarina
}

Yara Costa Netto Muniz

Tese apresentada à Faculdade de Medicina de Ribeirão Preto da Universidade de São Paulo, como requisito parcial para a obtenção do título de Doutora em Ciências - Área de concentração: Genética.

Orientador: Prof. Dr. Aguinaldo Luiz Simões

Ribeirão Preto

2008 


\begin{abstract}
AUTORIZO A REPRODUÇÃO E DIVULGAÇÃO TOTAL OU PARCIAL DESTE TRABALHO, POR QUALQUER MEIO CONVENCIONAL OU ELETRÔNICO, PARA FINS DE ESTUDO E PESQUISA, DESDE QUE CITADA A FONTE.
\end{abstract}

Muniz, Yara Costa Netto.

Marcadores Genéticos de Ancestralidade em Comunidades Fundadas por Açorianos na Ilha de Santa Catarina / Yara Costa Netto Muniz; orientador Aguinaldo Luiz Simões. - Ribeirão Preto, 2008.

$123 \mathrm{f}$.

Tese (Doutorado - Programa de Pós-Graduação em Genética.) - Faculdade de Medicina de Ribeirão Preto da Universidade de São Paulo.

1. Mistura étnica. 2. Comunidades de origem açoriana. 3. Marcadores informativos de ancestralidade. 5. Cromossomo Y 4. Genética de populações humanas. I. Titulo. 
FOLHA DE APROVAÇÃO

Yara Costa Netto Muniz

Marcadores Genéticos de Ancestralidade em Comunidades Fundadas por Açorianos na Ilha de Santa Catarina

Tese apresentada à Faculdade de Medicina de Ribeirão Preto da Universidade de São Paulo, como requisito parcial para a obtenção do título de Doutora em Ciências - Área de concentração: Genética.

Aprovado em:

Banca Examinadora

Prof. Dr.

Instituição:

Assinatura:

Prof. Dr.

Instituição:

Assinatura:

Prof. Dr.

Instituição:

Assinatura:

Prof. Dr.

Instituição:

Assinatura:

Prof. Dr.

Instituição:

Assinatura: 


\section{Rancha de Amar a Jlha}

(Hino de Florianópolis)

Zininho

Um pedacinha de terra

Perdida na mar!...

Num pedacinha de terra,

Belezas sem par!...

Jamais a natureza

Reuniu tanta beleza

Jamais algum paeta

Teve tanta, pra cantar!...

Num pedacinha de terra

Belezas sem par!

Jlha da maça faceira

Da velha rendeira tradicianal

Jlha da welha figueira

Onde em tarde fagueira

Vau ler meu jarnal

Tua lagaa farmasa

Ternura de rasa

Paema aa luar

Cristal ande a lua vaidasa

Sestrasa, dengasa

Vem se espelhar.

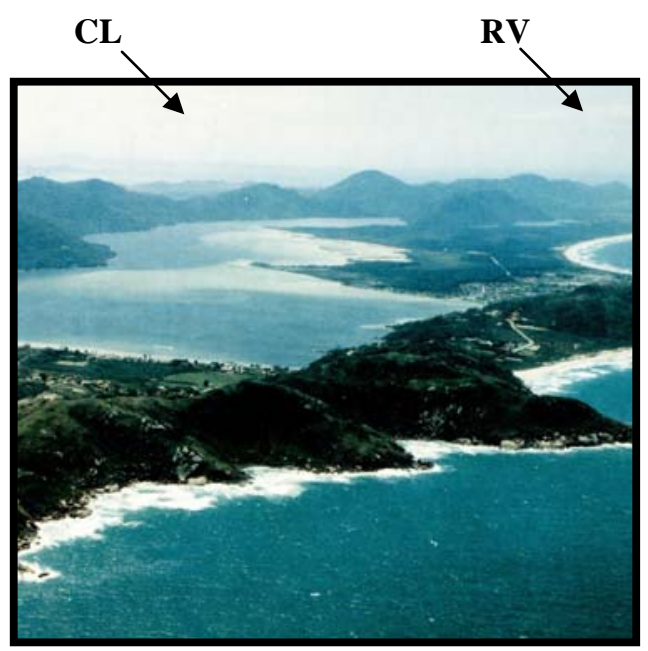

Foto da capa: Vista aérea da Lagoa da Conceição, de Flávio R. Berger (postal).

Direitos: Kreativ Artes Gráficas Ltda.

As setas indicam a localização das duas comunidades analisadas neste estudo, Costa da Lagoa (CL) e São João do Rio Vermelho (RV). 
"Para ser grande, sê inteira: nada

Teu exagera an exclui. Sê tada em cada caisa. Sãe quanta és Na mínima que fazes. Assim em cada laga a lua tada Brilha, parque alta vive."

"...Parque eu sau da tamanha da que veja E nãa da tamanha da minha altura..." 
Dedica sempre a minha auá Zilda (ín memarian)

"Tua palawra, tua histária Tua verdade fazenda escala E tua ausência fazenda silência em tada lugar" (Jeatra Mágica)

Lembranças carinhasas... Saudades! 
Dedica também:

\section{Aas meus pais $\underline{\mathcal{E} l z a}$ e Miltan \\ à minha irmã Camila \\ $\mathcal{E}$ aas meus irmãas Renata e Marcela}

Engraçada cama as wezes a distância física se tarna um detalhe... Parque uacês sempre estãa tãa perta. Acredita que a que nas une nãa sãa apenas as laças genéticas, mas cam certeza, de uma farma muita mais farte, as laças de amar. Ama vacês da funda da caraçãa! 


\section{Agradecimentos}

Lá se foram quatro anos! Hoje percebo o que realmente quer dizer "o tempo voa!". Voa mesmo... e foram tantas coisas vividas, aprendidas e sonhadas... e agora essa etapa chega ao fim. Mais uma, de muitas que já foram e de outras tantas que virão... Mas como em qualquer outra, esta não foi uma conquista solitária, foi construída em conjunto com pessoas especiais que, muitas vezes até sem saber, me ajudaram muito. Então quero deixar claro:

\section{Vocês também fazem parte dessa conquista!}

E aqui segue os meus agradecimentos sinceros:

Primeiramente às comunidades da Costa da Lagoa e de São João do Rio Vermelho e aos doadores do HMOSC. Foi com essa colaboração que pude montar a parte mais importante do meu trabalho, a amostra, sem a qual não existiria esta tese.

Ao meu orientador Prof. Dr. Aguinaldo Luiz Simões, pela oportunidade de realizar mais este trabalho. E agora me dou conta que lá se foram sete anos... Agradeço imensamente pela orientação prestada, pelas ótimas sugestões, pelos ensinamentos que extrapolam a área técnica, pelas explicações, discussões e pela confiança a mim depositada. Minha admiração profunda e amizade sincera.

À amiga e "orientadora eterna" Profa. Dra. Ilíada Rainha de Souza, pela grande colaboração neste trabalho e por todas as outras. Pela doação das amostras. Pelas longas conversas. Pelo exemplo de pessoa e profissional. Por todo o apoio e incentivo que sempre me dedicou e ainda dedica. Chego a acreditar que às vezes ela acredita mais em mim do que eu mesma... Muito carinho, muita admiração e uma grande amizade.

A todos os professores do Departamento de Genética da FMRP, pelos ensinamentos durante estes anos;

Aos funcionários do departamento pela acolhida e ajuda. Em especial à Maria Aparecida e a Susie, secretárias do departamento, pela enorme paciência, pelo apoio nos momentos difíceis e pelo carinho.

Aos professores da graduação em Biologia da UFSC, que por dois anos foram também meus colegas e que são de certa forma responsáveis por eu amar tanto a profissão que escolhi.

Ao $C N P q$, pelo auxílio financeiro recebido para o desenvolvimento desta tese. 
Aos meus lindos amigos - Porque como diz a canção:

\section{"Amiga é caisa para se guardar/De laixa de sete chaves/Dentra da caraçãa/ (...) Amiga é caisa para se guardar/ Na lada esquerda da peita/ Mesma que a tempa e a distância digam nãa/ Mesma esquecenda a cançãa) O que imparta é auvir) A uaz que uem da caraçãa..." (Miltan Nascimenta)}

Ao Marcelo, pelo apoio e colaboração durante esses anos no trabalho e principalmente na minha vida. Pela ajuda na prática, nas análises, no texto, nas noites viradas, pelas valiosas críticas e discussões, pelo apoio irrestrito e incansável a qualquer hora, pelas broncas (nem todas, né?). Mas principalmente por todo o carinho, companheirismo e amizade que com certeza serão eternos. Não conseguiria sem você. Tu és muito especial! Sempre morarás no meu coração!

Renata, "égua da amiga" de todas as horas! Pela divisão da casa, do brigadeiro, do leite com toddy, da diversão. Pelo carinho imenso, pelas risadas fartas, pelas histórias vividas, pela cumplicidade conquistada, pelas conversas incontáveis... Por me acolher e me apresentar à linda e inesquecível Paris. Pela amizade forte mesmo quando distante. Linda, tu és inexplicável!

Maria e Ana Lúcia, pela impagável e incansável ajuda na parte laboratorial durante estes longos e belos anos. E junto com a Edna pela amizade e carinho que sempre me dispensaram. Pelas palavras doces nas horas desesperadoras. Pelas risadas e conversas agradáveis. Nenhum “dez real” pagaria. Vocês são lindas demais!

Á Cláudia, pelo auxílio nas análises e na parte prática. Pelas conversas divertidas e desabafos. Ao Celso, pelo auxílio nas análises estatísticas. E claro, aos dois pela grande amizade, trocas de experiências e exemplo. Só tenho a desejar tudo de bom para vocês e suas lindas famílias!

Ao pessoal do LAPOGE que sempre estiveram disponíveis, pelas trocas de experiências e momentos de discussão. Em especial à Sandra e ao Tiago que me ajudaram muito na tipagem do cromossomo Y na amostra do HMOSC.

Débora, Juliana, Jeanne,Jussara e Daniel, por toda a diversão que passamos (e passaremos) juntos. Por todas as histórias. Pelo grande carinho que me dedicam mesmo quando longe. E pela nossa amizade que com certeza será pra sempre!

Aos amigos que fiz no Laboratório: Sandra, Lusitano, Isabel, Lenize, Mônica e Ricardo, pela prazerosa companhia e grande amizade. 
Aos amigos de bloco, Bete, Eliana, Eddy, Profa. Dra. Eucléia, Marcela, Rosana e aos demais amigos do departamento de genética por todo o apoio e amizade.

Aos amigos do circo e que me ensinaram a ter força, flexibilidade, atenção, equilíbrio e perseverança, não só no picadeiro, mas na vida! E que a diversão faz toda diferença! Em especial á Gabi, à Julia e ao André, companheiros de risos, de madrugada, de música, de muita conversa e cumplicidade. Vocês são simplesmente um espetáculo!

Ao Marson, nunca aprendi tanto em tão pouco. Inclusive sobre mim mesma. Sempre disposto a ouvir minhas histórias intermináveis, a conversar sobre qualquer assunto, a dar explicações pacientes e convincentes às minhas dúvidas sobre fenômenos naturais e tantas outras. Pessoa admirável e profissional exemplar (de verdade). Muito carinho e desejo de que isso seja só começo de uma grande e linda amizade.

Em Floripa amigos que fazem ou fizeram meu retorno sempre mais coloridos e agradáveis! Vivi e Luci, amizade sincera como a de vocês são poucas e extremamente valiosas. Obrigada por não me esquecerem mesmo quando eu sumo e assim, se fazerem sempre presentes na minha vida! Ao Oto, meu amigo lindo que me diverte muito. Ao Derli, e todas as horas agradáveis cheirando a cappuccino. Ao Guilherme, pelos momentos lindos, carinho extremo e ensinamentos eternos que nunca vou esquecer e guardo com muito carinho. Vocês são show!

Ao Raul (meu afilhado) pelos momentos divertidos e relaxantes que tivemos (e sempre teremos).

Aos meus alunos que durante dois anos me ensinaram mais do que eu a eles. E me fizeram ter certeza dos meus caminhos futuros. Pois "menar que meu sanha eu nãa passa ser!" (Lindalf Bell). Ser professor é uma arte difícil, mas extremamente compensadora.

Ao grupo de extensão em Educação Ambiental da UFSC, onde trabalhei por quase dois anos e aprendi muito com as discussões, aulas, reuniões, festas. E em especial as professoras Verinha e a Tânia que admiro e guardo um carinho enorme, exemplos de profissionais e grandes amigas.

Ao Programa Especial de Treinamento (PET-Capes) onde tive ensinamentos que levarei para o resto da minha vida e que fizeram dessa etapa com certeza mais leve. Em especial ás amigas Catia e Isa, pela amizade linda duradoura. E à ex-tutora Yara minha admiração sincera. 
E claro a minha linda família:

À minha tia Darcy que sempre fez de tudo que estava ao seu alcance e muito mais para me agradar. Por estar sempre presente na minha vida. Pelos momentos divertidos. Por toda a ajuda. Não tenho como agradecer...

À minha irmã Camila. Ela é a minha rosa! E que me ajuda diariamente a entender que atitudes valem muito mais que palavras. Amo-a do fundo do meu coração, pela amizade, cumplicidade e carinho de quem sempre dividiu seu espaço comigo, a barriga, o colo, o quarto... Sinto falta desse tempo. Sei que agora seguimos cada uma um caminho, mas sei que sempre estaremos uma ao alcance da outra. Ao Ricardo, a quem admiro muito, por ser um cunhado bem mais que perfeito, por tudo que fez e faz por mim e, principalmente, pela Cá. E agora ao Bernardo, que ainda sem vir ao mundo já me faz uma pessoa bem mais completa e FELIZ!

Aos meus queridos irmãos Renato e Marcelo, embora mais novos (ops... eu não sou a caçula?!) sempre me ensinaram muito. Por toda a diversão que já passamos. Por todo o companheirismo, amor, amizade e mimos. Sei que estarão do meu lado sempre a qualquer hora em qualquer lugar. E isso não tem preço. Valeu muito mesmo! Amo muitos vocês dois!

Aos meus pais, Elza e Milton, por TUDO que representam na minha vida! Pelo amor sem tamanho que sempre me dedicaram. Pela confiança extrema que depositam em mim. Por serem meus maiores incentivadores. Pelo apoio irrestrito. Por me ajudarem até hoje a me construir como pessoa e a acreditar que eu posso. Pelo exemplo profissional e pessoal. Vocês são as pessoas mais admiráveis que conheço, com certeza os melhores pais que alguém pode ter. Amo-os incondicionalmente!!!

A toda minha família. Obrigado do fundo do meu coração!!

Muita alerigada a tadas!!!

“...Sá enquanta eu respirar uau me lembrar de vacê(s)

Sá enquanta eu respirar...” (J eatra mágica) 


\section{RESUMO}

MUNIZ, Y. C. N. Marcadores Genéticos de Ancestralidade em Comunidades Fundadas por Açorianos na Ilha de Santa Catarina. 2008. 123p. Tese (Doutorado) - Faculdade de Medicina de Ribeirão Preto, Universidade de São Paulo, Ribeirão Preto.

As comunidades da Costa da Lagoa (CL) e São João do Rio Vermelho (RV) estão localizadas na Ilha de Santa Catarina, Sul do Brasil, e foram colonizadas na segunda metade do século XVIII por imigrantes vindos do Arquipélago de Açores. Estudos demográficos e genéticos mostraram também a presença de componentes africanos e ameríndios. CL é considerada isolada devido à sua localização geográfica e RV está em fase de quebra de isolado pelo aumento de migração, principalmente nos últimos 20 anos. Os objetivos deste estudo foram verificar a hipótese dos diferentes graus de isolamento nas duas comunidades, estimar as proporções de mistura étnica, assim como estabelecer comparações entre elas e com portugueses, especialmente açorianos. As freqüências de oito AIMs (FY, RB, LPL, AT3, Sb19.3, APO, PV92 e CYP1A1) e dos STRs do haplótipo estendido do cromossomo Y foram então estimadas nas comunidades de CL $(n=120)$, RV $(n=163)$ e na amostra urbana HM $(\mathrm{n}=50)$ a partir de PCR e PCR-RFLP. A informação obtida a partir das mesmas foi comparada com resultados de estudos históricos, demográficos e genéticos prévios realizados nestas comunidades. As análises estatísticas empregaram programas já descritos (GENEPOP, DISPAN, GDA, ARLEQUIN, STRUCTURE, MVSP e ADMIX 2 e 3). Com relação ao cromossomo Y, concluímos que as duas comunidades ainda apresentam semelhanças considerando as análises de diferenciação gênica. Isto pode ser devido à origem comum e recente e à proximidade geográfica, o que torna possível um fluxo de homens entre as duas comunidades. Entretanto, o acréscimo no número de marcadores ligados ao cromossomo $\mathrm{Y}$ permitiu a diferenciação entre estas duas comunidades, como mostram os valores de $F_{S T}$ e de diferenciação haplotípica. As estimativas de mistura indicam preponderância do componente europeu. Entretanto, dada à indisponibilidade da literatura, faz-se ainda necessária uma escolha mais adequada das freqüências parentais no caso dos Y-STRs. Admitindo que os AIMs sejam marcadores mais eficientes em estimativas de mistura étnica, dado seus altos diferenciais de freqüência alélica entre populações parentais, as contribuições de populações não européias (principalmente africanas) observadas mantém a hipótese de cruzamentos preferenciais entre homens portugueses e mulheres ameríndias e/ou africanas na formação das comunidades. 


\section{ABSTRACT}

\section{MUNIZ, Y. C. N. Ancestry Informative Markers in Partially isolated communities}

founded by Azoreans in the Santa Catarina Island. 2008. 123p. Thesis (Doctoral) Faculdade de Medicina de Ribeirão Preto, Universidade de São Paulo, Ribeirão Preto.

The communities of Costa da Lagoa (CL) and São João do Rio Vermelho (RV) are located on Santa Catarina Island, southern Brazil, and were settled on the second half of XVIII century by immigrants came from Azores Archipelago. Demographic and genetic studies have also been indicated the presence of African and Amerindian components. CL is considered genetically isolated due to its geographic localization and isolate breaking is occurring in RV due to the increased migration to the local, mainly in the last 20 years. The aims of the present study were to verify the hypothesis of the different degrees of isolation in the two communities, to estimate the proportions of ethnic admixture, as well as to establish comparisons between them and with Portuguese, particularly Azoreans. Allele frequencies of eigth AIMs (FY, RB, LPL, AT3, Sb19.3, APO, PV92 e CYP1A1) and of the extended Y haplotype STRs were estimated in the CL $(n=120)$, RV $(n=163)$ and in the urban sample HM $(\mathrm{n}=50)$ by means of PCR and PCR-RFLP. These data were compared with previous results from historical, demographical and genetical studies realized in these communities. Statistical analysis were carried out employing the GENEPOP, DISPAN, GDA, ARLEQUIN, STRUCTURE, MVSP and ADMIX 2 and 3 softwares. The communities showed more similarity in relation to $\mathrm{Y}$ chromosome on the analysis of gene differentiation, which could be due to the recent and common origin and the geographic proximity, and the interchange mainly male-mediated between them. However, the increased number of Y-linked STRs made possible the differentiation between these communities, as depicted by the $F_{S T}$ values and the haplotypic differentiation. The ethnic admixture estimates detected a major European contribution but, due to the literature unavailability, a more suitable choice of the parental frequencies for the Y-STRs estimates is needed. Once AIMs are markers more efficient than Y-STRs on admixture estimates, due to their large allele frequency differentials between parental populations, the non-european contributions (mainly Africans) observed support the hypothesis of biased mating between Portuguese men and Amerindian and/or African women during the formation of these communities. 


\section{SUMÁRIO}

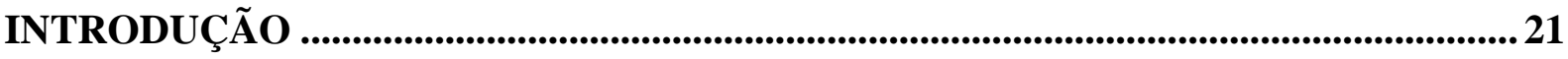

O processo de colonização do litoral sul do país ......................................................................21

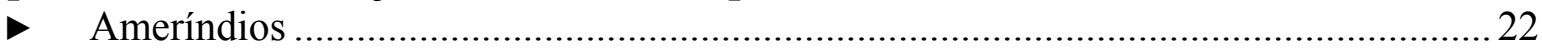

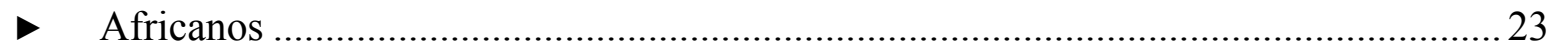

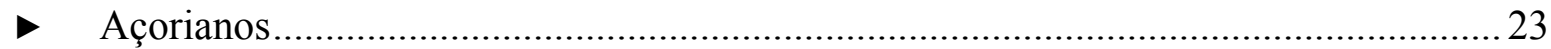

As Comunidades Estudadas ..................................................................................................... 24

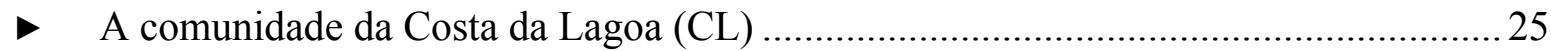

- A comunidade de São João do Rio Vermelho (RV)......................................................26

Estudos Previamente Realizados Nestas Comunidades ......................................................... 27

Polimorfismos Genéticos......................................................................................................30

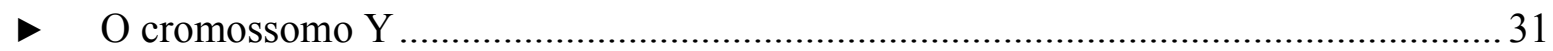

- Marcadores Informativos de Ancestralidade (AIMs) ....................................................33

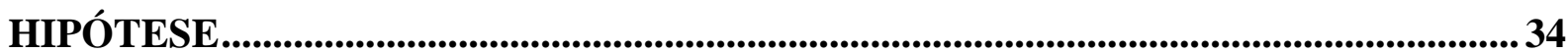

OBJETIVO ……..................................................................................................................... 35

MATERIAL E MÉTODOS ................................................................................................... 36

Esquema do trabalho .................................................................................................................... 36

As Comunidades ……..................................................................................................................... 37

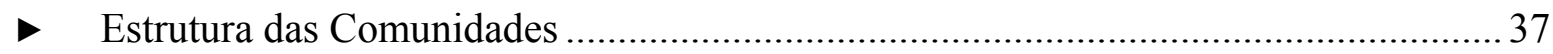

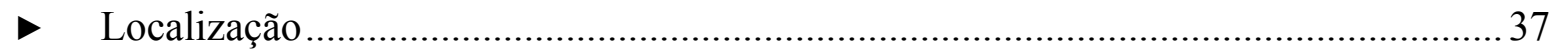

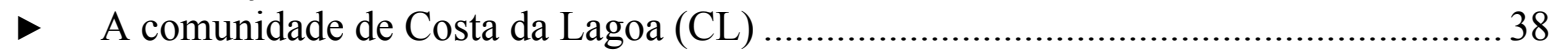

- A comunidade de São João do Rio Vermelho (RV)...................................................... 38

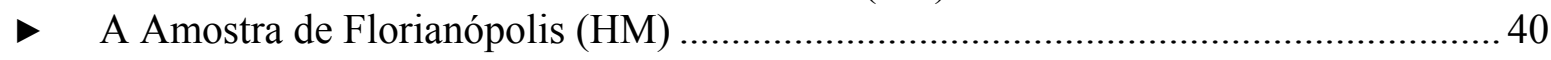

Aspectos Éticos.............................................................................................................................. 40

Coleta e Conservação do Material ........................................................................................ 41

Conservação do Material ....................................................................................................... 42

Marcadores Genéticos Investigados ..........................................................................................4 43

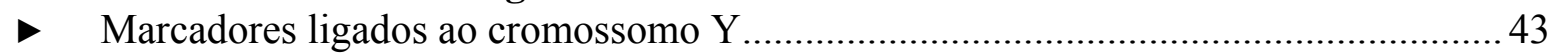

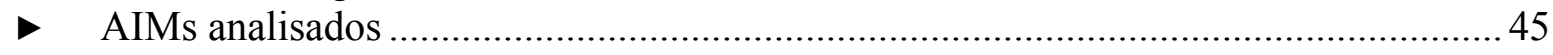

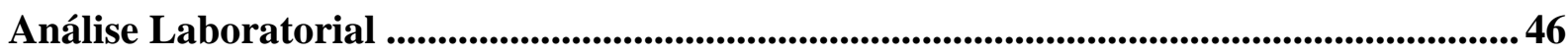

Extração do DNA Genômico ……...............................................................................46

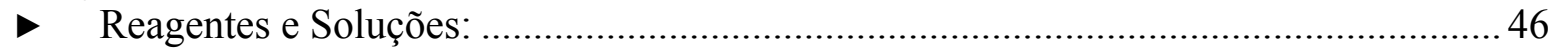

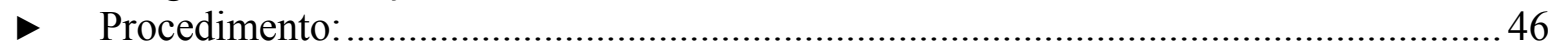

Reação em Cadeia da Polimerase (PCR)..................................................................................4 47

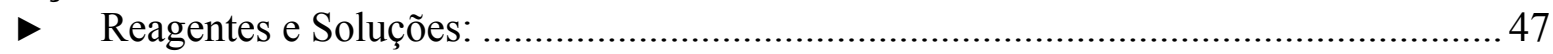

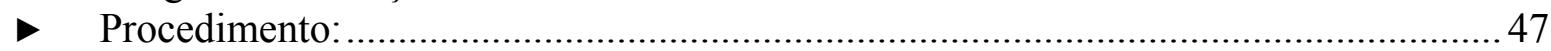

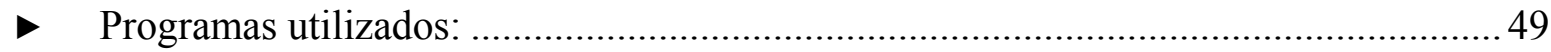


Reação de Restrição ...................................................................................................................49

Análise do Produto Amplificado ...............................................................................................51

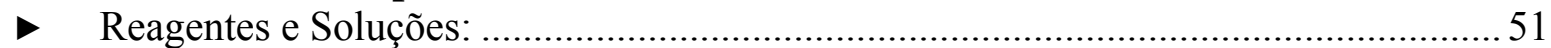

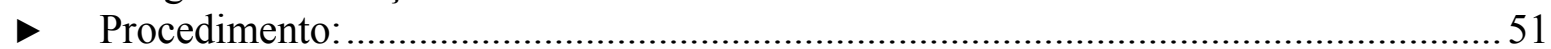

Coloração com Nitrato de Prata e Secagem do Gel....................................................................55

- Reagentes e soluções: ..........................................................................................5

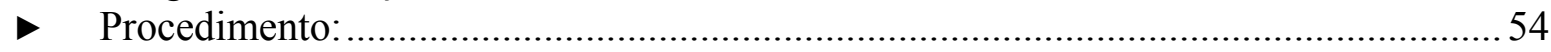

Determinação Fenotípica (Nomenclatura) ..........................................................................5 54

Tamanho Amostral...............................................................................................................56

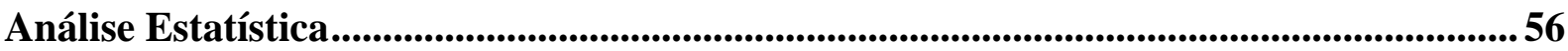

- Freqüências Gênicas em Populações Ancestrais ............................................................56

- Estimativas das freqüências alélicas e genotípicas ........................................................58

- Diversidade haplotípica .............................................................................................59

- Análise de Variância Molecular (AMOVA) ………………………………………......59

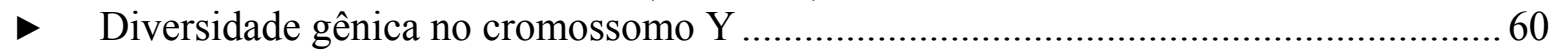

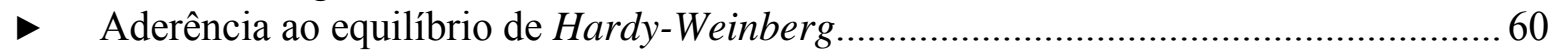

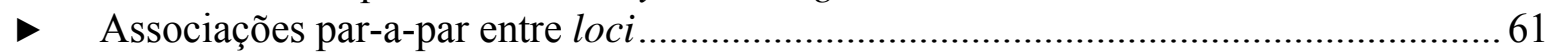

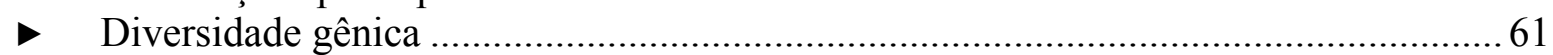

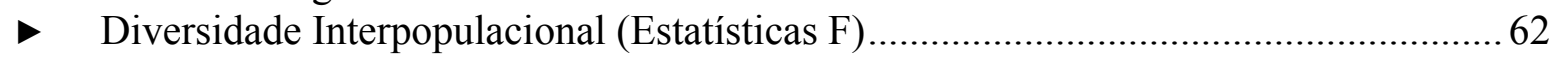

- Diferenciação genética das populações ............................................................................63

- Inferência de Estrutura Populacional (STRUCTURE)......................................................63 63

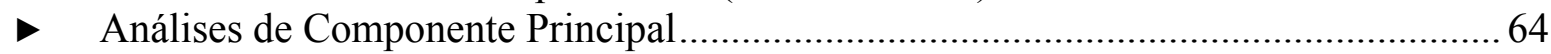

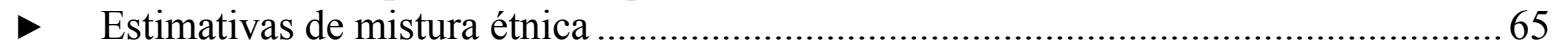

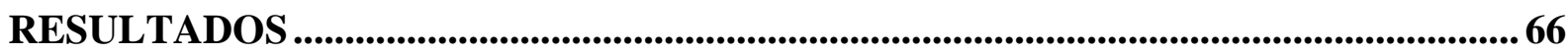

Cromossomo Y. Freqüências Alélicas e Diversidade Genética ............................................. 66

Diversidade Haplotípica e Análise de Variância Molecular (AMOVA).............................. 72

AIMs. Freqüências Alélicas e Diversidade Genética............................................................... 78

Equilíbrio de Hardy-Weinberg ..................................................................................................... 80

Desequilíbrio de Ligação................................................................................................................. 81

Diferenciação Populacional ........................................................................................................ 82

Diversidade Interpopulacional (Estatísticas F),....................................................................83

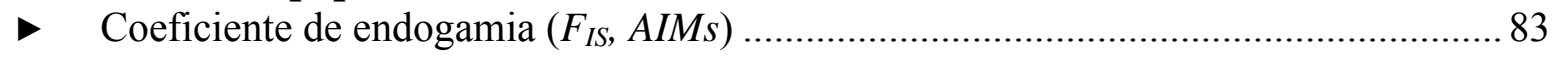

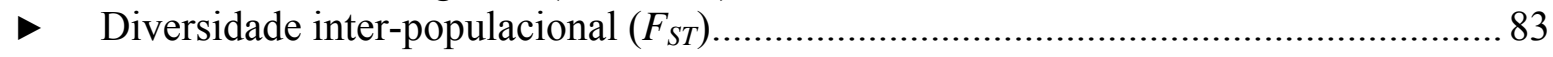

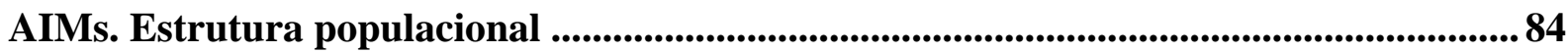

AnáliseS de Componente Principal...............................................................................................86

Estimativas de Mistura Étnica .........................................................................................92

DISCUSSÃO

Cromossomo Y. Freqüências Alélicas e Diversidade Genética ..............................................93

Diversidade Haplotípica e AMOVA .....................................................................................93

AIMs. Freqüências Alélicas e Diversidade Genética.................................................................95 


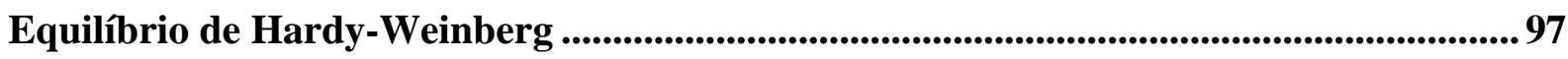

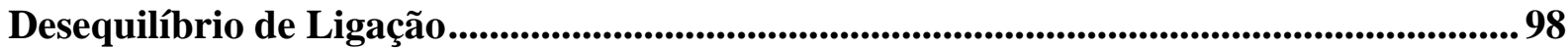

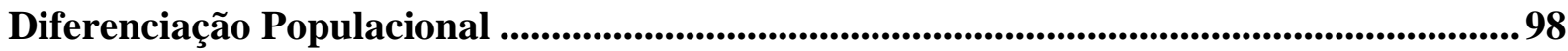

Diversidade Interpopulacional (Estatísticas F).......................................................100

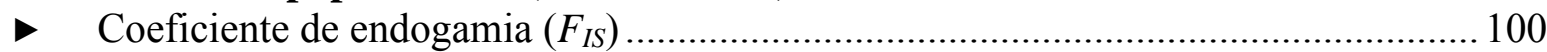

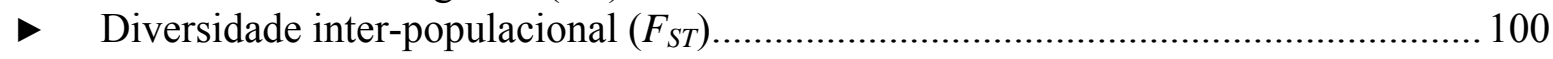

AIMs. Estrutura Populacional ....................................................................................... 101

Análises de Componente Principal ............................................................................................ 102

Estimativas de Mistura Étnica .............................................................................. 103

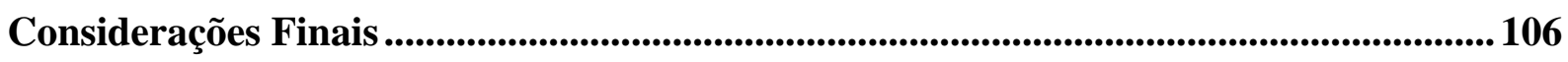

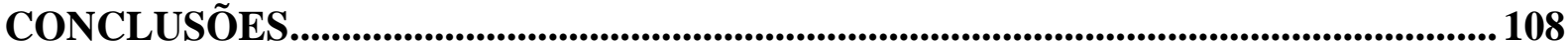

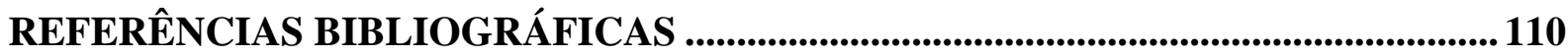

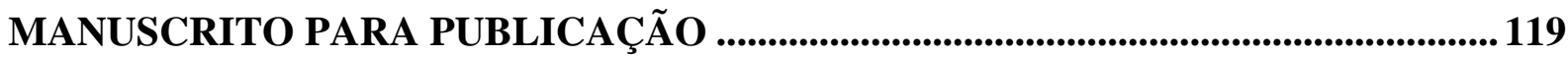




\section{LISTA TABELAS}

Tabela 1: Localização citogenética, núcleo de repetição, seqüência dos primers, tamanho do fragmento e alelos descritos para os loci ligados ao cromossomo $\mathrm{Y}$ analisados no presente trabalho.

Tabela 2: Localização citogenética, enzimas de restrição, seqüência dos primers e condições de PCR dos oito AIMs analisados.

Tabela 3: Condições de PCR para os loci analisados no presente trabalho (quantidade para 1 reação).

Tabela 4: Condições de Reação de Restrição para os SNPs analisados (quantidade em $\mu \mathrm{L}$ para 1 reação).

Tabela 5: Condições específicas para eletroforese de cada locus analisado no presente trabalho.

Tabela 6: Distribuição das freqüências alélicas de 10 Y-STRs nas comunidades analisadas (CL e RV), na amostra urbana (HM) e nas parentais açoriana (FERNANDES \& BREHN, 2003), africana (ROSA et al., 2006) e ameríndia (LEITE et al., 2008). As freqüências dos loci DYS19, DYS390, DYS391, DYS392 e DYS393 são de MUNIZ (2003).

Tabela 7: Diversidade gênica $\left(H_{S}\right)$ de 10 STRs ligados ao cromossomo Y nas duas comunidades analisadas (CL e RV), na amostra urbana (HM) e nas parentais açoriana (FERNANDES \& BHREN, 2003). Africana (ROSA et al., 2006) e Ameríndia (LEITE et al., 2008). As $H_{S}$ dos loci DYS19, DYS390, DYS391, DYS392 e DYS 393 são de MUNIZ (2003).

Tabela 8: Distribuição das freqüências haplotípicas dos STRs DYS385a/b nas duas comunidades analisadas (CL e RV), na amostra urbana (HM) e nas populações parentais açoriana (FERNANDES \& BHREN., 2003), africana (ROSA et al., 2006) e ameríndia (LEITE et al., 2008).

Tabela 9: Descrição e Freqüência absoluta dos haplótipos estendidos nas duas populações (CL e RV) e na amostra urbana (HM) estudadas.

Tabela 10: Diversidade haplotípica $(h)$ do haplótipo estendido do cromossomo Y nas duas comunidades analisadas (CL e RV) e na amostra urbana (HM) e nas parentais açoriana (FERNANDES \& BHREN, 2003). Africana (ARROYO-PARDO et al., 2005) e Ameríndia (LEITE et al., 2008)

Tabela 11: Freqüências alélicas dos oito AIMs e diversidade genética $\left(H_{S}\right)$ nas duas comunidades (CL e RV) e na população urbana (HM). As freqüências se referem ao alelo CYP1A1*2C e aos alelos *1 dos demais loci. 
Tabela 12: Diversidade genética $\left(H_{S}\right)$ obtida a partir dos AIMs FY, RB, LPL, AT3, Sb19.3 e APO entre diferentes populações mundiais.....

Tabela 13: Probabilidade de desvio casual segundo teste exato (GUO \& THOMPSON 1992) na verificação do equilíbrio de Hardy-Weinberg. * Os valores significativos antes e ** após a correção Bonferroni $\left(\alpha_{\text {Bonf }}<0,002\right)$.

Tabela 14: Diferenciação gênica baseada nos loci do haplótipo estendido do cromossomo Y entre as duas comunidades (CL e RV) e a amostra urbana (HM) aqui estudadas. *Valores significativos $(p<0,05)$

Tabela 15: Valores de $F_{I S}$ nas populações analisadas. *Valores com intervalo de confiança $(95 \%)$ significativos.

Tabela 16: Valores de $F_{S T}$ nos diferentes pares de populações obtidos a partir dos 7 AIMs (exceto o CYP1A1). *Valores com intervalo de confiança (95\%) significativos.

Tabela 17: Valores de $F_{S T}$ nos diferentes pares de populações obtidos a partir dos STRs do haplótipo estendido do cromossomo Y. Todos os valores são significativos, intervalo de confiança $95 \%$.

Tabela 18: Características dos componentes principais baseados nas freqüências alélicas de seis AIMs (FY, RB, LPL, AT3, Sb19.3 e APO).

Tabela 19: Pesos (loadings) das variáveis na resolução dos componentes principais na análise baseada em seis AIMs (FY, RB, LPL, AT3, Sb19.3 e APO). 88

Tabela 20. Características dos componentes principais baseados nas freqüências alélicas de sete AIMs (FY, RB, LPL, AT3, Sb19.3, APO e PV92).

Tabela 21: Pesos (loadings) das variáveis na resolução dos componentes principais na análise baseada em sete AIMs (FY, RB, LPL, AT3, Sb19.3, APO e PV92). 89

Tabela 22. Características dos componentes principais obtidos a partir do haplótipo estendido do cromossomo $\mathrm{Y}$.

Tabela 23. Características dos componentes principais obtidos a partir do haplótipo estendido do cromossomo Y

Tabela 24: Estimativa de mistura étnica nas comunidades analisadas considerando os dois grupos de marcadores analisados (AIMS e Haplótipo estendido do Y) e as estimativas já publicadas com marcadores clássicos e HLA nas comunidades estudadas (CL e RV) e população urbanas (HM). 


\section{LISTA FIGURAS}

Figura 1: Localização geográfica das duas comunidades, CL e RV, analisadas no presente trabalho.

Figura 2: Vista parcial da comunidade da CL. A) Restaurante de frutos do mar à esquerda; B) Um dos núcleos, a Vila, onde se situam: a Igreja (centro), a creche, o posto de saúde e a escola; C) Vista geral da comunidade; D) Casa típica da comunidade com um trapiche e duas casinhas para barco.

Figura 3: A comunidade de São João do Rio Vermelho. A) Casa em estilo açoriano; B) Posto de Saúde; C) Igreja da comunidade; D) Rodovia SC-406.

Figura 4: Localização cromossômica aproximada dos loci de STRs ligados ao cromossomo Y que compõe o haplótipo estendido (a partir de informações do site http://www.yhrd.org/index.html - Acessado em 09/01/2008).....

Figura 5: Comparação gráfica das freqüências alélicas de três STRs-Y (DYS19, DSYS389I e DYS389II) com as freqüências das populações parentais açorina, africana e ameríndia.

Figura 6: Comparação gráfica das freqüências alélicas de três STRs-Y (DYS390, DSYS391 e DYS392) com as freqüências das populações parentais açorina, africana e ameríndia.

Figura 7: Comparação gráfica das freqüências alélicas de três STRs-Y (DYS393, SYS438 e DYS439I) com as freqüências das populações parentais açorina, africana e ameríndia

Figura 8: Comparação gráfica das freqüências haplotípicas do STR-Y DYS385ab com as freqüências das populações parentais açoriana (FERNANDES \& BREHN, 2003), africana (ROSA et al., 2006) e ameríndia (LEITE et al., 2008).

Figura 9: Comparação das freqüências dos AIMs (alelo *1) entre as comunidades de CL, RV e a população urbana (HM) com as populações parentais EUropéia (Portugueses; TOMÁS et al., 2002), AFricana (PARRA et al., 1998) e AMeríndia (LUIZON et al., 2008a) (Materiais e Métodos, pág 56-58pp).

Figura 10: (A) Estrutura populacional nas comunidades e na população urbana em comparação com populações parentais; Africana, Ameríndia e Européia, obtido a partir de sete AIMs. Foram admitidas k=3 populações, 30.000 interações no período burn-in e 100.000 interações nas estimativas dos parâmetros. (B) Proporção de associação de cada população a cada um dos três clusters.

Figura 11: Agrupamento dos indivíduos (círculos) das comunidades de CL, RV e da amostra do HM, de acordo a contribuição dos grupos étnicos parentais: Africano, Ameríndio e Europeu. 
Figura 12: Componentes principais obtidos a partir de seis AIMs (FY, RB, LPL, AT3, Sb19.3 e APO) que relacionam as freqüências alélicas das populações analisadas com populações mundiais. Populações africanas e européias (PARRA et al., 2001; TOMÁS et al., 2002), afro- e euro-americanas (PARRA et al., 1998), euro-brasileiros (ZEMBRZUSKI et al., 2006), e populações indígenas da América do Norte (dbSNP, PSU-ANTH) e da Amazônia Brasileira (LUIZON et al., 2008a).

Figura 13: Componentes principais obtidos a partir da adição do locus PV92 aos seis AIMs da Figura 2, que relacionam as freqüências alélicas das populações analisadas com populações mundiais. Populações africanas e européias (PARRA et al., 2001; TOMÁS et al., 2002), afroe euro-americanas (PARRA et al., 1998), euro-brasileiros (ZEMBRZUSKI et al., 2006), e populações indígenas da América do Norte (dbSNP, PSU-ANTH) e da Amazônia Brasileira (LUIZON et al., 2008a). 88

Figura 14: Componentes principais obtidos a partir do haplótipo estendido do cromossomo $\mathrm{Y}$, que relacionam as freqüências alélicas das populações analisadas com populações mundiais: açorianos (FERNANDES \& BREHM, 2003 e ROSA et al., 2005), africanos (ARROYO-PARDO et al., 2005) e ameríndios (LEITE et al., 2008).

Figura 15: Componentes principais obtidos a partir do haplótipo mínimo do cromossomo Y, que relacionam as freqüências alélicas das populações analisadas com populações mundiais (açorianos, FERNANDES \& BREHM, 2003; portugueses, PONTES et al., 2007; e espanhóis, MARTÍN et al. 2004; africanos, ARROYO-PARDO et al., 2005 e ROSA et al., 2005, e ameríndios, LEITE et al., 2008) e urbanas brasileiras das cinco regiões (N, CO, SE, NE e S, GRATTAPAGLIA et al., 2005), de São Paulo (SP, GÓES et al., 2008) e de Santa Catarina (SC, CAÍNÉ et al., 2005). 


\section{INTRODUÇÃO}

Considerando que neste século tem havido uma significativa redução no número de populações isoladas em todo o mundo, o estudo das que restam torna-se bastante relevante uma vez que populações isoladas representam uma grande oportunidade para a compreensão da dinâmica e da estrutura populacionais.

Diante disto, as comunidades fundadas por açorianos aqui estudadas são parcialmente isoladas, de acesso fácil quando comparadas a outros isolados, e de origem predominantemente européia (açoriana), o que torna seu estudo interessante do ponto de vista genético uma vez que a maioria dos isolados estudados no Brasil é de afro-descendentes ou de ameríndios.

\section{O PROCESSO DE COLONIZAÇÃO DO LITORAL SUL DO PAÍS}

O povoamento efetivo do litoral do sul do Brasil ocorreu somente em meados do século XVII quando núcleos básicos agro-comerciais foram fundados ao longo da costa catarinense quando bandeirantes deslocaram-se das capitanias de São Vicente em direção ao sul do Brasil (FARIAS, 1998): São Francisco do Sul (fundada em 1658), Desterro (hoje Florianópolis, fundada em 1662), Laguna (em 1682). Por volta de 1662, Francisco Dias Velho fixou-se na Ilha de Santa Catarina que havia passado por várias tentativas fracassadas de povoação (SANTOS, 1974). Dias Velho governou até 1679, quando foi morto por piratas. Tal fato colocou os poucos moradores (cerca de 600) em pânico, que fugiram deixando a ilha novamente quase despovoada. Em 1711, a Ilha contava com apenas 110 pessoas (PIAZZA, 1982). 
A coroa Portuguesa não abria mão de seu desejo de domínio até a foz do rio da Prata, por onde passava a prata explorada pelos espanhóis. Após vários anos de conflito e negociações diplomáticas para definir os limites entre as duas nações, D. João V nomeou Alexandre de Gusmão como diplomata, que usou a estratégia de povoar as regiões litigiosas e fazer valer o princípio do uti possidetis (quem povoa domina) (PIAZZA, 1982; FLORES, 2000).

Nesta conjuntura, a ilha de Santa Catarina passou a representar a principal prioridade da colonização do sul brasileiro, representando o atalaia do domínio português. Mas quem povoou a ilha?

\section{- Ameríndios}

Três grupos indígenas são identificados no estado de SC: os Guaranis, os Xokleng e os Kaingang, pertencentes aos troncos lingüísticos Tupi, Macro Ge e Gê, respectivamente (RODRIGUES, 1986). Os Guaranis (Carijós) estabeleceram-se no litoral e eram grupos sedentários, os Xokleng eram seminômades e viviam no planalto e os Kaingang viviam nas florestas, entre o litoral e o planalto e eram nômades (SANTOS, 1973). Hoje, os últimos remanescentes destas tribos estão distribuídos nas poucas reservas do Estado, em Ibirama, Chimbangue (Trentin) e na Serra do Taboleiro (NAMEN, 1994; SANTOS, 1998).

O litoral de Santa Catarina era habitado pelos índios Carijós, indígenas da nação tupiguarani. (FLORES, 2000). Durante os séculos XVI e XVII, estes foram exterminados pela escravidão a que foram submetidos. Anualmente embarcavam principalmente para a região sudeste cerca de 12.000 carijós aprisionados pelos bandeirantes paulistas, até que no fim do séc. XVII estes desapareceram quase que por completo do litoral catarinense. Quando os açorianos chegaram, encontraram a Ilha de Santa Catarina quase deserta de gente. Os carijós, que aí viveram, tinham sido mortos ou levados como escravos. Os que conseguiram 
sobreviver fugiram para o interior, procurando refúgio no mato (SANTOS, 1974; 1998; FLORES, 2000).

\section{- Africanos}

O componente africano surge na população brasileira durante a prática escravagista que teve início por volta de 1538 e, por longos 350 anos, o negro foi considerado simples mercadoria (SALZANO \& FREIRE-MAIA, 1970). Durante este período, foram embarcados no litoral atlântico da África, em diversos locais da costa que se estende do Senegal ao sul de Angola e ao norte da Namíbia e, também, no litoral da África Oriental, de Moçambique à Somália (TAVARES, 1988). Estes entraram no país principalmente pelo Maranhão, Bahia, Rio de Janeiro e Pernambuco, sendo posteriormente distribuídos para as demais regiões (CONRAD, 1985).

Um dos primeiros registros discriminatórios da população de escravos africanos em Santa Catarina data de 1803 indicava 4.215 escravos (24\% da população). Esta proporção atingiu um ápice em 1823 com 15.533 cativos (33\% da população), declinando para 1.838 (9\% da população) em 1887 (PIAZZA, 1999). Na ilha de Santa Catarina, a população escrava era de 4.400 indivíduos em 1854, 26\% do total de escravos de Santa Catarina, caindo em oito anos para 2.820, 17\% da província (PIAZZA, 1999).

\section{- Açorianos}

Como Portugal necessitava de um grande contingente de pessoas para ocupar o sul da colônia, evitando perder estas terras para a Espanha, a atenção das autoridades voltou-se para as ilhas atlânticas - Açores e Madeira, que sofriam uma forte crise de subsistência devido à densidade populacional elevada e, portanto, havia desejo destes ilhéus em partir. O edital do rei estimulando as famílias a emigrarem deixava claro o propósito de ocupação do território, 
através de uma colonização de base estável. Tal edital requeria famílias jovens e numerosas, com homens experientes no amanho das terras e na criação de gado e mulheres habituadas às lides domésticas e destras na arte da fiação. Assim, foi estabelecida idade máxima de 30 anos para as mulheres e 40 para os homens que desejassem embarcar para as novas terras (FLORES, 2000). Desta forma, dois problemas puderam ser resolvidos de uma única vez, a crise de subsistência no arquipélago e a ocupação do sul do Brasil.

A coroa financiou o transporte e o assentamento de aproximadamente 6.000 colonos (5.420 açorianos e 580 madeirenses, entre homens, mulheres e crianças) em Santa Catarina e no Rio Grande do Sul, entre janeiro de 1748 a julho de 1756 (PIAZZA, 1982). Sendo até então a maior corrente migratória sistemática dirigida para o Brasil (SANTOS, 1974). Destes, 4.500 estabeleceram-se no litoral catarinense, dinamizando o processo sócio-demográficocultural, haja vista que a população de origem européia e escravos era cerca de 2.000 habitantes (FARIAS, 1998).

\section{AS COMUNIDADES ESTUDADAS}

Quando estes imigrantes açorianos estabeleceram-se na Ilha de Santa Catarina várias comunidades foram fundadas, entre elas as da Costa da Lagoa (CL) e São João do Rio Vermelho (RV) (Figura 1). Assim, estas comunidades têm suas estruturas étnicas formadas por descendentes de imigrantes europeus (açorianos, portugueses e espanhóis), africanos e ameríndios, tendo sido classificadas como predominantemente européias (MUNIZ, et al. 1986; SOUZA, 2001; MUNIZ, 2003). 


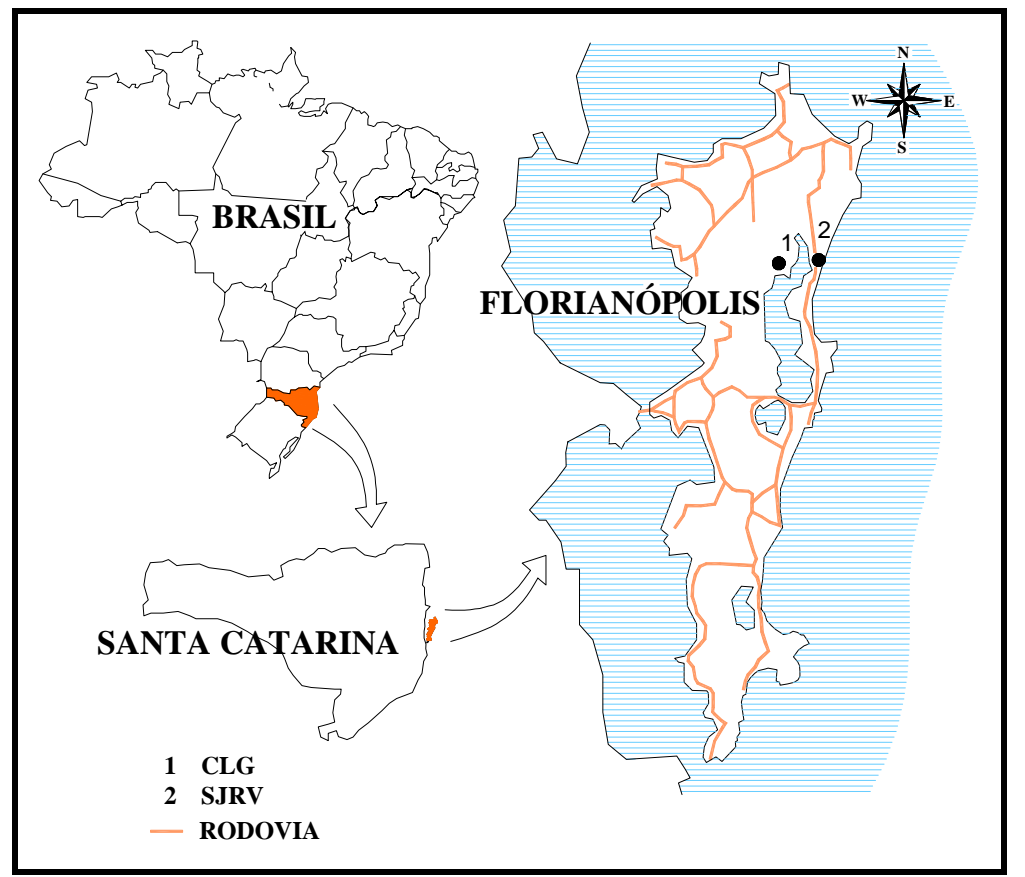

Figura 1: Localização geográfica das duas comunidades, CL e RV, analisadas no presente trabalho.

\section{- A comunidade da Costa da Lagoa (CL)}

A CL apresenta entre 100 e 200 famílias distribuídas em pequenos núcleos (GIMENO, 1992). Os habitantes vivem principalmente da pesca, embora a agricultura seja praticada em pequena escala. Algumas mulheres confeccionam e vendem renda de bilro, uma tradição vinda dos Açores. Mais recentemente, há famílias que são proprietárias de restaurantes e bares, e vivem do turismo.

Segundo relatos de moradores, logo após sua fundação a comunidade era próspera, com inúmeros engenhos de cana de açúcar e de mandioca e cafezais, sendo que o caminho até a freguesia da Lagoa era mantido para passagens de carros de boi e escoamento da produção. Com a abolição da escravatura, começou a decadência da região, visto que a economia era totalmente dependente da mão-de-obra escrava. Hoje há apenas um engenho modelo funcionando e a manutenção da estrada foi abandonada. 
Por sua formação histórica e geográfica, o povoamento da CL é provavelmente um dos últimos redutos com elementos da cultura açoriana da Ilha. Apresenta um patrimônio cultural com mais de 200 anos, com engenhos, casarões, utensílios agrícolas e de pesca, além de aspectos culturais como hábitos, costumes e a linguagem.

Até um passado recente, esta comunidade permaneceu à margem dos processos de urbanização. Somente em 1982 a energia elétrica foi instalada no local. O transporte existente é um sistema de barcas instalado em 1986 e que, desde 1993, é de responsabilidade da cooperativa de pescadores da comunidade. Tal meio de transporte atua como redutor de impacto da pressão populacional externa, conferindo à comunidade um considerável isolamento geográfico (GIMENO, 1992).

\section{- A comunidade de São João do Rio Vermelho (RV)}

O povoamento de São João do Rio Vermelho (RV) começou na segunda metade do século XVIII, com a chegada dos açorianos, a partir de 1748. Mas também há descendentes de espanhóis e africanos (GOULART, 1986).

Desde o início de sua ocupação, localiza-se em RV a maior área da ilha cultivada com mandioca e a maior concentração de engenhos, cerca de cinqüenta, dos quais ainda hoje restam nove. Por volta de 1930, alguns homens começaram a sair do povoado para trabalhar na pesca em alto-mar, determinando o declínio da pesca artesanal, além de acelerar a crise na lavoura, que já era grande na década de 1950 (LUPI \& LUPI, 1989).

Somente a partir da década de 60 é que a comunidade passou a receber novos moradores, coincidente com a implantação de uma linha de ônibus no local ou mesmo em decorrência disto. Em 1970, a rodovia SC 406 foi construída, com uma extensão de 8 Km, 
ligando a comunidade aos distritos vizinhos. A construção desta rodovia facilitou o fluxo de seus habitantes e a instalação de novos moradores (LUPI \& LUPI, 1989).

Nos últimos trinta anos a comunidade vem passando por modificações nas relações sociais do grupo devido à grande mobilidade dos cônjuges, o que indica quebra do isolado anteriormente existente.

\section{ESTUDOS PREVIAMENTE REALIZADOS NESTAS COMUNIDADES}

Um elevado coeficiente médio de endocruzamento $\left(\bar{F}=1379 \times 10^{-5}\right)$ foi observado na CL (MUNIZ et al. 1986) quando comparado com os valores encontrados para a cidade de Florianópolis ( $\bar{F}=5 \times 10^{-5}$, AGOSTINI \& MEIRELLES-NASSER, 1986). A freqüência de casais consangüíneos é igual a 21,7\% em Costa da Lagoa, valor que contrasta com os 3,2\% observados na comunidade de Rio Vermelho (BITTENCOURT, 1993). Em 1996, o coeficiente médio de endocruzamento $(F)$ encontrado para CL foi de $500 \times 10^{-5}$ e, em 1998, foi de $85 \times 10^{-5}$ para RV. Estes dados confirmam o diferente grau de isolamento destas duas comunidades (SALDANHA et al., 1996; ALVES-JÚNIOR et al., 1998 e SOUZA et al., 2003).

RV era considerada isolada em relação ao resto da população da Ilha de Santa Catarina, pois possuía valores altos para a distância marital, raio matrimonial médio e raio migracional médio, em relação aos valores de outras populações, mostrando uma diminuição do grau de isolamento (GOULART, 1986). Dos indivíduos residentes em RV amostrados ao acaso, apenas 32,5\% são nativos enquanto que na CL este valor é de $87 \%$ (ROSA et al., 1998). 
A taxa de migração bruta $(m)$ é de 0,24 e o índice de isolamento é igual a 16 . Este último valor, segundo WRIGTH (1969), permite considerar que a probabilidade da deriva estar atuando não seja desprezível.

Na comunidade de RV $m=0,73$ e, embora o número de imigrantes nesta comunidade seja 4,5 vezes maior do que na comunidade da CL, o número de imigrantes da $\mathrm{Ne}$ (população efetiva) passa a ser 3,8 vezes maior. Devido à migração efetiva (me) ser elevada e a população efetiva ( $\mathrm{Ne}$ ) igual a 740, o índice de isolamento é 451, o que indica que a deriva genética não tem um papel relevante na variação das freqüências alélicas nesta população.

Com base nestes parâmetros podemos dizer que CL ainda se constitui num isolado genético além de geográfico, com uma grande probabilidade de ter como fator evolutivo mais atuante, na alteração das freqüências alélicas, a deriva genética (SOUZA et al., 2003). Enquanto que em RV está ocorrendo uma quebra de isolado, podendo ser a migração o fator evolutivo preponderante na alteração das freqüências alélicas (MUNIZ, 1999; SOUZA et al., 2003).

De acordo com estudos demográficos (MUNIZ et al., 1986; PILLMAN, 1989; BITTENCOURT, 1993) e históricos (GIMENO, 1992), a classificação étnica baseada somente na aparência física indicava que a CL deveria ser considerada díbrida (origem caucasóide e negróide), sendo classificada como predominantemente branca (MUNIZ et al., 1986). Estudos com marcadores bioquímicos (ABO, RH-D-RH-CE, GPA-GPB (MNSs), HBB, HP, TF, ACP1, CP e AK) indicam também a presença de marcadores ameríndios na população na proporção de $7,7 \% \pm 8,7$, a proporção de africanos é de $17,3 \% \pm 8,9$, sendo os restantes 75,0\% $\pm 10,7 \%$ de europeus com MSE (Mean Square Error=Erro Quadrado Médio) igual a 3,3\% (SOUZA et al., 2003). 
Estudos mais recentes com marcadores de DNA mostram diferentes estimativas de mistura quando comparamos loci STRs (Short Tandem Repeats=seqüências curtas repetidas consecutivamente) autossômicos com loci STR e uma inserção Alu do cromossomo Y. Para os primeiros a estimativa de mistura se adequou ao modelo tríbrido em CL, com predominância do componente português $93,5 \%( \pm 5,9)$, seguido do componente africano $4,1 \%( \pm 3,9)$ e ameríndio $2,4 \%( \pm 2,9)$. Enquanto que para os loci do cromossomo Y a estimativa de mistura étnica se adequou ao modelo diíbrido, indicando uma contribuição quase que exclusiva de portugueses, $95,6 \%( \pm 10,6)$ e sendo inconsistente para o componente ameríndio (MUNIZ, 2003).

A comunidade de $\mathrm{RV}$, assim como a anterior, também foi classificada como predominantemente branca (GOULART, 1986), mas estudos com marcadores bioquímicos (ABO, RHD-RHCE, GPA-GPB (MNSs), HBB, HP, TF, ACP1, CP e AK) indicam uma

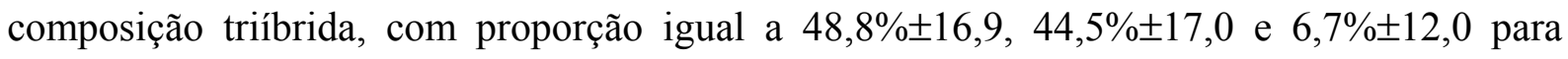
africanos, portugueses e ameríndios, respectivamente, com o $M S E=6,6 \%$. Com a retirada do locus GPA-GPB, devido a superestimativa da freqüência do alelo GPB* ${ }^{\mathrm{u}}$, estas proporções

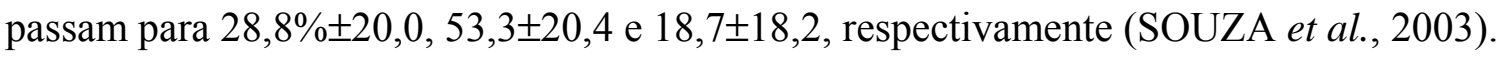

Da mesma forma, estudos recentes com marcadores de DNA mostraram diferenças na estimativa de mistura quando comparamos loci autossômicos com loci do cromossomo Y. Para os loci autossômicos a estimativa de mistura se adequou ao modelo tríbrido em RV, com predominância do componente português $80,6 \%( \pm 4,8)$, seguido do componente africano $12,6 \%( \pm 1,1)$ e ameríndio $6,8 \%( \pm 5,5)$. Enquanto que para os loci do cromossomo $\mathrm{Y}$ a estimativa de mistura étnica se adequou ao modelo díbrido, sendo inconsistente para o componente ameríndio e indicando uma contribuição quase que exclusiva de portugueses, $94,1 \%( \pm 6,2)($ MUNIZ, 2003). 
Estas discrepâncias nos dados de mistura étnica são observadas também em outras comunidades isoladas brasileiras e têm sido explicadas por terem sido fundadas prevalentemente por homens europeus e mulheres ameríndias ou afro-descentes. Entretanto, os registros históricos sobre a fundação de CL e RV relatam a vinda de famílias completas do Arquipélago de Açores, que teriam ocupado uma região sem habitantes indígenas, pois estes teriam sido eliminados previamente.

A elucidação destas discrepâncias pode ser obtida pela ampliação do estudo de polimorfismos genéticos nestas comunidades, especialmente o haplótipo estendido do cromossomo Y e marcadores informativos de ancestralidade (AIMs; Ancestry Informative Markers).

\section{POLIMORFISMOS GENÉTICOS}

Os polimorfismos de DNA podem ser classificados em três categorias: (a) Mutação puntual, onde uma mesma posição é ocupada por nucleotídeos diferentes, como os SNPs $($ Single Nucleotide Polymorphisms $=$ polimorfismos de nucleotídeos únicos $)($ COLLINS et al . 1998); (b) Inserção/deleção, em que trechos da seqüência podem estar presentes ou ausentes em alguns cromossomos (BATZER et al., 1990); e (c) polimorfismos do tipo VNTR (Variable Number of Tandem Repeats = números variável de seqüências repetidas consecutivamente) (NAKAMURA et al., 1987).

Desde 1978, com a descrição dos RFLPs (Restriction Fragments Length Polymorphisms $=$ polimorfismo de comprimento do fragmento restrição) (KAN \& DOZI, 1978), atualmente também chamados de RSPs (Restriction Site Polymorphisms = polimorfismo de sítio de restrição) (JORDE et al., 1995), abriu-se à perspectiva de estudar a variabilidade da seqüência de nucleotídeos diretamente e não mais através das proteínas por 
elas codificadas. Nestes casos é possível verificar que mutações de ponto levam à perda ou ganho de sítios de restrição para endonucleases, enzimas capazes de reconhecer e clivar uma seqüência específica de DNA.

Os VNTRs podem ser divididos em 3 subclasses: (a) satélites, que são segmentos repetidos de 100 ou mais nucleotídeos (nt); (b) minissatélites repetições de 10 a 100nt; e (c) microssatélites, também chamados STRs, com repetições de 2 a 6nt. A diferença entre os mini e os microssatélites deve-se a diferentes mecanismos genéticos envolvidos na expansão dos mesmos. Ainda se conhece pouco sobre os mecanismos de expansão dos elementos de 7 a 9nt, por isso, permanecem ainda sem uma definição (CHAMBERS \& MacAVOY, 2000). No genoma humano ocorre em média 1 STR a cada 6 ou 10kb (BECKMAN \& WEBER, 1992).

Todos estes polimorfismos de DNA podem ser encontrados no genoma nuclear, estando presente em uma cópia por célula. Neste caso, podemos diferenciar estes loci quando estão presentes em cromossomos autossômicos ou sexuais. Os mesmos também podem ser encontrados no genoma mitocondrial. Diferentes respostas podem ser encontradas dependendo da localização do loci analisado.

\section{- O cromossomo $\mathrm{Y}$}

Atualmente, encontra-se disponível uma lista ampla de marcadores do tipo STRs que abrangem todos os cromossomos do genoma humano, incluindo o Y, Y-STR (KAYSER et al. 2001). Com este tipo de marcador a variabilidade de alelos presentes em uma população é tanta que podem ser obtidas altas taxas de discriminação entre os indivíduos quando múltiplos loci STRs são examinados (SCHUMM, 1996).

O cromossomo Y representa $2 \%$ do genoma humano e tem aproximadamente $60 \mathrm{Mb}$. A maior parte $(95 \%)$ é constituída de região não recombinante (NRY). Apresenta alta taxa de 
mutação $(0,033$ mutações por Mb por geração), baixa diversidade $(0,2 \%)$ e tem cerca de 100 mil anos (estimativa baseada no tamanho efetivo da população humana) (QUINTANAMURCI et al., 2001).

Os STRs ligados à NRY possuem herança paterna e é transmitida sem mudanças dos pais para os filhos, exceto por ocorrência de mutações que se acumulam através de gerações (KAYSER et al., 1997). A vantagem da análise de polimorfismos da NRY é que facilmente pode-se construir haplótipos altamente informativos, os quais caracterizam cada linhagem masculina (KAYSER et al., 2001). Isto porque o alto nível de variabilidade destes STRs, resultante da alta taxa de mutação, permite uma boa análise da variabilidade entre e dentro das populações (KAYSER et al., 1997).

Todas estas características fizeram com que os polimorfismos do cromossomo Y se tornassem amplamente utilizados em aplicações forenses e análises de paternidade (QUINTANA-MURCI et al., 2001), na elucidação de aspectos da evolução humana (KAYSER et al., 2001) e na investigação de histórias populacionais, principalmente de núcleos de divergência recente (PÉREZ-LEZAUN et al., 1997), como é o caso das comunidades do presente estudo.

Atualmente, um grupo de onze loci é referido como haplótipo estendido e incluí marcadores usados na prática forense (DYS19; DYS385a/b; DYS389I-DYS389II; DYS390; DYS391; DYS392; DYS393; DYS385a,b, DYS438, DYS439). Havendo um banco de dados de diversas populações mundiais disponível on line para comparação, facilitando muito os estudos populacionais (http://www.yhrd.org/index.html). 


\section{- Marcadores Informativos de Ancestralidade (AIMs)}

A maioria dos marcadores genéticos apresenta freqüências polimórficas tanto nas populações híbridas como naquelas representativas das populações ancestrais. Entretanto, existem marcadores genéticos que exibem diferenciais de freqüência alélica $(\delta)$ superiores a $30 \%$ entre quaisquer duas populações parentais, primeiramente chamados de PSAs (Population-Specific Alleles; SHRIVER et al., 1997), e atualmente denominados por AIMs (BONILLA et al., 2004).

A precisão nas estimativas de mistura étnica é diretamente dependente do valor de $\delta$ dos marcadores utilizados, portanto os AIMs são os marcadores ideais para estimativas eficazes de mistura populacional (PARRA et al., 1998; PARRA et al., 2001), e na detecção de associações alélicas entre loci não ligados (PFAFF et al., 2001).

Os AIMs já foram empregados em estimativas de mistura étnica em populações das Américas do Norte, Central e do Sul. A mistura africana foi preponderante nas populações Afro-americanas (PARRA et al., 1998, PARRA et al., 2001). Por outro lado, a mistura Européia é preponderante nas estimativas de Mexicanos-americanos e Porto-riquenhos, denominados como Hispânicos (SALARI et al., 2005, CHOUDHRY et al., 2006), e a ancestralidade Ameríndia é maior dentre os Mexicanos (MARTINEZ-MARIGNAC et al., 2007) e quase completa dentre os Nativos Americanos do México (BONILLA et al., 2005) e da Amazônia Brasileira (LUIZON et al., 2008a).

Conforme exposto acima, estes loci podem gerar estimativas mais precisas da composição étnica da população triíbrida brasileira, assim como das comunidades isoladas fundadas por açorianos do presente estudo. 


\section{HIPÓTESE}

As comunidades da Costa da Lagoa e de São João do Rio Vermelho representam oportunidades de se comparar informações históricas com dados genéticos, onde é possível demonstrar como tais fatores podem interagir. Deste modo, os dados genéticos corroborariam as informações históricas e eventualmente preencheriam seus vazios.

Vários marcadores genéticos foram previamente estudados nestas comunidades, como: albumina, haptoglobina, transferrina, adenilato quinase, hemoglobina, fosfatase ácida, ceruloplasmina, grupos sangüíneos (ABO, RHD, RHCE, GPA, GPB) e HLA (SALDANHA et al., 1996; ALVES-JÚNIOR, et al. 1998; SOUZA et al., 2003). Estudos estes recentemente ampliados por um conjunto de marcadores moleculares que incluiu STRs autossômicos (HUMCSF1PO, HUMTH01, HUMTPOX; D5S818, D7S820, D13S317, D16S539, MJD) e ligados ao cromossomo Y (DYS19, DYS390, DYS391, DYS392, DYS393, YAP) (MUNIZ, 2003).

Os estudos realizados até o presente momento mostram divergências nas estimativas de mistura quando comparamos marcadores autossômicos e marcadores ligados ao cromossomo Y. Portanto, ciente das respostas que os marcadores do tipo STRs ligados ao cromossomo Y e AIMs autossômicos podem oferecer para o entendimento da formação das comunidades do presente estudo, estes marcadores podem ajudar a explicar tais divergências. Adicionalmente, os mesmos poderão ajudar a investigar a hipótese de ocorrência de cruzamento preferencial (homens portugueses-açorianos com mulheres de origem ameríndia e ou africana) durante a formação destas comunidades. 


\section{OBJETIVO}

O conjunto de marcadores escolhido para atingir os objetivos propostos inclui: STRs ligados ao cromossomo Y que complementam o haplótipo definido como estendido e com freqüências previamente descritas para diversas populações, incluindo Portugal e Açores (DYS385a,b; DYS389I-DYS389II; DYS438; DYS439). Ainda serão analisados AIMs que possuem grandes diferenciais de freqüência alélica entre africanos, europeus e ameríndios (FY-Null, RB2300, LPL, AT3-ID, Sb19.3, APO, PV92 e CYP1A1*2C). Por fim, uma análise completa e conjunta de todos os dados já disponíveis para estas comunidades de STRs autossômicos e marcadores clássicos.

Desta forma, este trabalho tem como objetivo Ampliar o estudo de marcadores nestas comunidades com o haplótipo estendido de STRs do cromossomo Y e AIMs autossômicos, visando melhorar as estimativas de mistura étnica e investigar a hipótese de que há cruzamento preferencial durante a formação destas comunidades. E para isso:

(a) quantificar as proporções de mistura étnica para estes marcadores de linhagem paterna e AIMs nas duas comunidades;

(b) estabelecer comparações com populações portuguesas, especialmente açorianas;

(c) verificar a eventual existência de alelos e/ou haplótipos característicos destas comunidades ou que indiquem a contribuição das populações ancestrais.

(d) Verificar se estes marcadores são capazes de diferenciar estas duas comunidades de origem comum e recente, Costa da Lagoa e São João do Rio Vermelho. 


\section{MATERIAL E MÉTODOS}

\section{ESQUEMA DO TRABALHO}

A Ilha de Santa Catarina foi colonizada na segunda metade do século XVIII por famílias completas de imigrantes vindos do Arquipélago de Açores e que fundaram várias comunidades, entre elas a da Costa da Lagoa (CL) e a de São João do Rio Vermelho (RV). Estas comunidades são estudadas por pesquisadores da Universidade Federal de Santa Catarina (UFSC) desde a década de 80 (MUNIZ et al., 1986) e, desde 1994, os estudos são orientados pela professora $\mathrm{Dr}^{\mathrm{a}}$. Ilíada Rainha de Souza, responsável pelo Laboratório de Polimorfismos Genéticos (LAPOGE, BEG/CCB/UFSC). Vários marcadores genéticos (enzimas séricas, grupos sanguíneos, HLA, STRs autossômicos e ligados ao cromossomo Y) já foram analisados (SOUZA, 2001; SOUZA et al. 2003; MUNIZ, 2003).

Neste trabalho propomos a ampliação destes estudos com marcadores informativos de ancestralidade (AIMs) e STRs ligados ao cromossomo Y, no intuito de responder perguntas a respeito da real mistura acontecida desde a fundação destas comunidades. A informação destes novos marcadores, em conjunto com resultados de marcadores previamente estudados e re-analisados neste trabalho (ligados ao Y e STRs autossômicos), permitirão avaliar o grau de mistura étnica, estimar de diversidade genética, bem como comparar estas comunidades entre si e com populações parentais. As amostras de sangue de indivíduos pertencentes às comunidades de CL, RV e do HEMOSC (HM, Hemocentro de Santa Catarina) foram previamente coletadas e utilizadas em vários projetos anteriores pelas equipes do LAPOGE, onde estão armazenadas. 


\section{AS COMUNIDADES}

\section{- Estrutura das Comunidades}

As duas comunidades, Costa da Lagoa (CL) e São João do Rio Vermelho (RV), são povoamentos históricos na Ilha de Santa Catarina, que tiveram origem entre o século XVII e XVIII.

Os estudos genéticos com estas comunidades se iniciaram há 20 anos com um grupo de pesquisadores da Divisão de Genética do Departamento de Biologia Celular, Embriologia e Genética (BEG) da UFSC. Os primeiros estudos determinaram alguns parâmetros demográficos (MUNIZ et al., 1986) e genéticos (BITTENCOURT, 1993). Posteriormente, sob orientação da Prof ${ }^{a}$. Dr ${ }^{a}$. Ilíada Rainha de Souza foram feitos levantamentos das freqüências alélicas de alguns marcadores bioquímicos (hemoglobina, haptoglobina, transferrina, fosfatase ácida, adenilato quinase, ceruloplasmina, grupos sangüíneos $\mathrm{ABO}$, RHD, RHCE, GPA, GPB) e de novos dados demográficos, tais como: distribuição etária, distribuição sexual, distribuição racial, população reprodutora $\left(N_{\mathrm{r}}\right)$, população efetiva $\left(N_{\mathrm{e}}\right)$, migração efetiva $\left(m_{\mathrm{e}}\right)$ e índice de isolamento (i) (SALDANHA, 1996; ROSA, 1997; MUNIZ, 1999; ROSA et al., 1998; ALVES-JÚNIOR et al., 1998; SOUZA et al., 2003).

\section{- Localização}

As comunidades da CL e de RV estão localizadas no município de Florianópolis, capital do Estado de Santa Catarina, no Sul do Brasil. Este município está localizado na região litorânea do Estado, entre os paralelos de $27^{\circ} 10^{\prime}$ e $27^{\circ} 50^{\prime}$ de latitude sul e $48^{\circ} 25^{\prime}$ de longitude. Sua área está dividida em duas porções de terra separadas por um estreito de $500 \mathrm{~m}$ de largura. A porção continental possui $12,1 \mathrm{~km}^{2}$. A maior parte é composta pela Ilha de Santa 
Catarina, onde as duas comunidades estão localizadas. A Ilha possui $424,4 \mathrm{~km}^{2}$, com $54 \mathrm{~km}$ de extensão no sentido norte-sul e 18 km no sentido leste-oeste (site Florianópolis) (Figura 1).

\section{- A comunidade de Costa da Lagoa (CL)}

A comunidade da CL (Figura 2) está localizada no distrito da Lagoa da Conceição que teve sua origem a partir da Provisão Régia de 07/06/1750. Este distrito tem uma área total de $55,28 \mathrm{~km}^{2}$ (site Florianópolis).

A CL está distribuída ao longo do "Caminho Geral da Costa" (Figura 1), à margem oeste da Lagoa da Conceição, Ilha de Santa Catarina (PILLMAN, 1989) e cerca de 20 km do centro de Florianópolis. Por apresentar acessos terrestres precários, sendo que o meio de transporte utilizado pelos moradores é quase que exclusivamente lacustre, pode-se dizer que a comunidade encontra-se isolada geograficamente. Segundo censo do IBGE (1992), a comunidade da CL apresentava 533 indivíduos, distribuídos em seis núcleos.

Sustenta-se principalmente da pesca e, em pequena escala, da agricultura. As mulheres fabricam e vendem rendas de bilro e algumas famílias são proprietárias de restaurantes e bares e vivem do turismo (PILLMAN, 1989).

\section{- A comunidade de São João do Rio Vermelho (RV)}

A comunidade de RV (Figura 3) pertence ao distrito de mesmo nome e se originou a partir da Resolução Régia de 11/08/1831. Este distrito tem uma área total de 31,68 km² e fica localizado na parte nordeste da Ilha de Santa Catarina, limitado ao leste pelo oceano, ao norte pelos morros que o separam do distrito de Ingleses, a oeste por uma cadeia de morros que o separa do distrito de cachoeira do Bom Jesus e de Ratones e ao sul pela Lagoa da Conceição (Figura 1). 


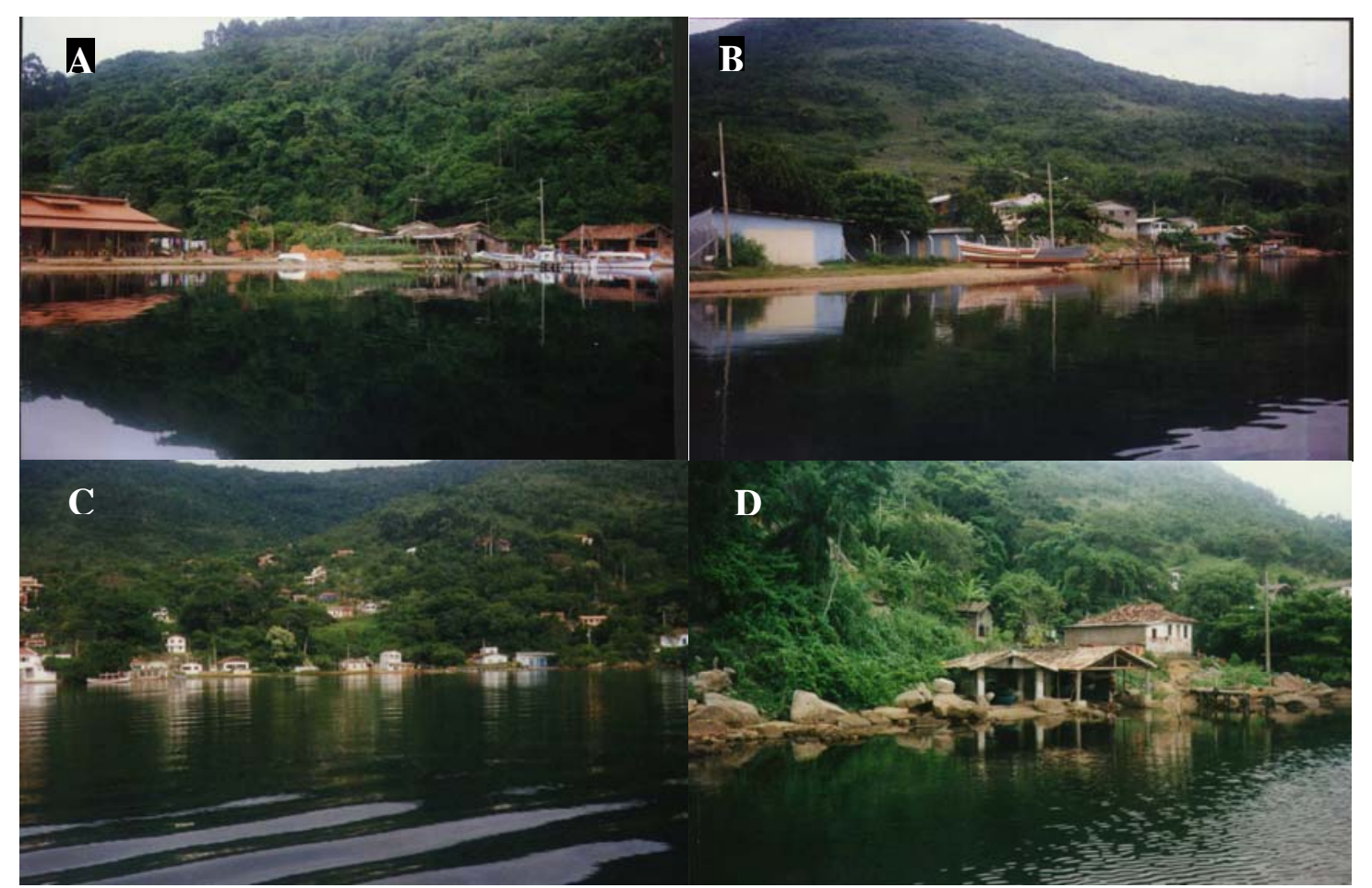

Figura 2: Vista parcial da comunidade da CL. A) Restaurante de frutos do mar à esquerda; B) Um dos núcleos, a Vila, onde se situam: a Igreja (centro), a creche, o posto de saúde e a escola; C) Vista geral da comunidade; D) Casa típica da comunidade com um trapiche e duas casinhas para barco.

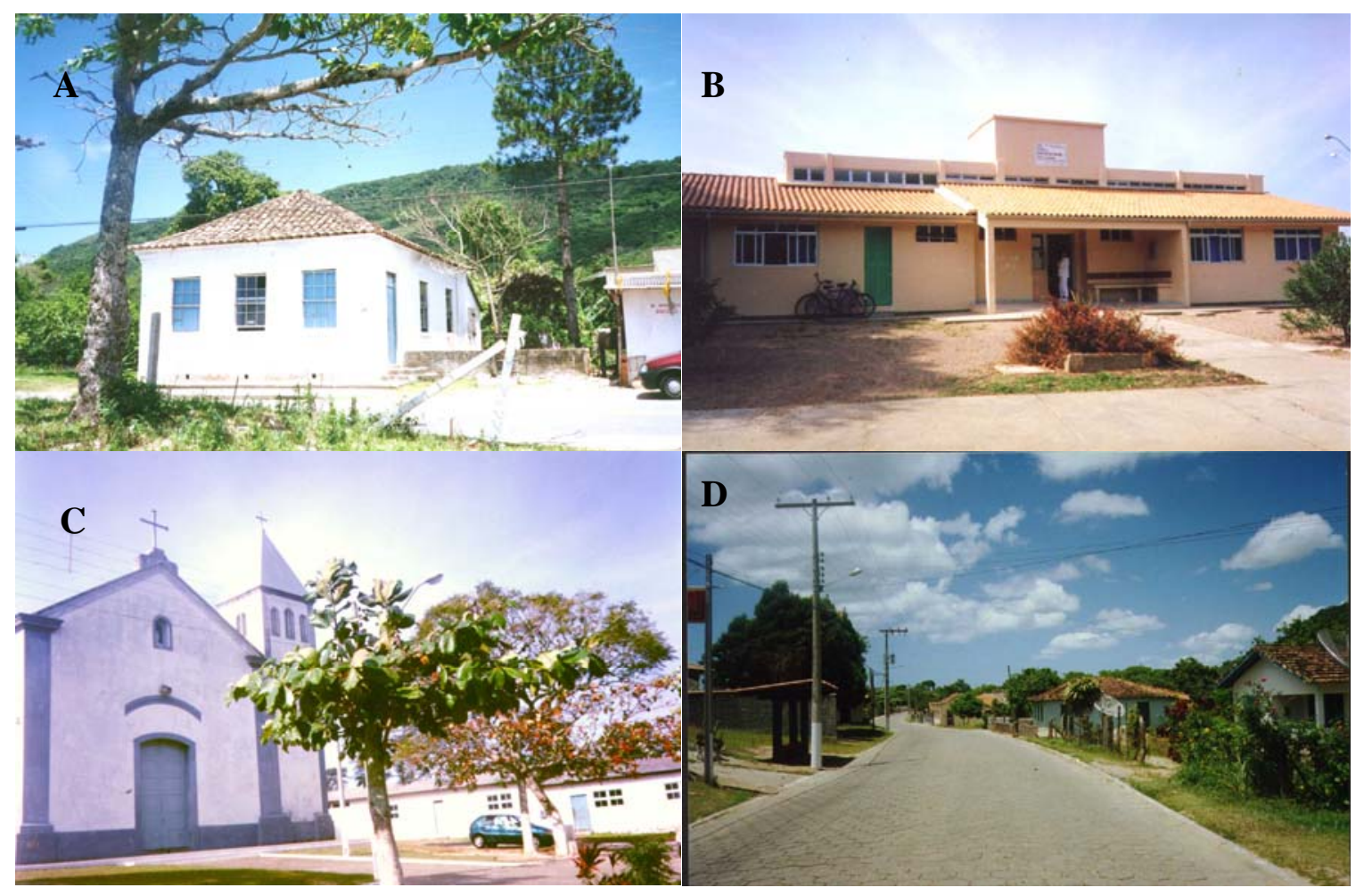

Figura 3: A comunidade de São João do Rio Vermelho. A) Casa em estilo açoriano; B) Posto de Saúde; C) Igreja da comunidade; D) Rodovia SC-406. 
São João do Rio Vermelho é um dos maiores distritos pertencentes ao município de Florianópolis e durante muitas décadas manteve-se isolado das comunidades vizinhas. Desde a década de 70 comunica-se com outras regiões pela rodovia SC-406, que corta o distrito e permite grande fluxo de seus moradores e facilita que novos habitantes cheguem à região. Segundo o censo do IBGE (1992), havia no distrito 1864 indivíduos.

Sustenta-se da pesca, mas muitos habitantes trabalham em serviços públicos urbanos e outros vivem do comércio local; os mais idosos sobrevivem ainda da lavoura e tem como tradição à confecção de rendas de bilro, principalmente pelas senhoras mais velhas (LUPI \& LUPI, 1989).

\section{- A Amostra de Florianópolis (HM)}

A amostra constitui-se de sangue de indivíduos doadores de sangue do HEMOSC (Centro de Hematologia e Hemoterapia de Santa Catarina; http://www.HEMOSC.org.br/), de ambos os sexos, com faixa etária entre 26 e 62 anos e, a grande maioria da capital do Estado, Florianópolis. Esses indivíduos são voluntários que consentiram que parte de seu sangue fosse também utilizada para fins de pesquisa. Parte desta amostra tiveram os loci do cromossomo Y tipados no LAPOGE, por Sandra Rachadel Torres e Tiago Moreti.

\section{ASPECTOS ÉTICOS}

No presente trabalho foi utilizado material coletado entre 1994 e 1999 por pesquisadores da UFSC e armazenado nesta Instituição. A utilização destas amostras foi autorizada pela Prof ${ }^{a}$. Dr ${ }^{\mathrm{a}}$. Ilíada Rainha de Souza, responsável pela guarda e coleta das mesmas. 
Como o início da coleta ocorreu em época anterior à promulgação da Resolução CNS 196/96 do Ministério da Saúde, não foi colhida assinatura em Termo de Consentimento Livre e Esclarecido (TCLE), entretanto a coleta se restringiu á doadores voluntários que deram seu consentimento verbal e após reunião de esclarecimento com representantes e lideres comunitários.

Esse projeto foi analisado e aprovado ad referendum pelo Comitê de Ética e Pesquisa da Instituição (Hospital das Clínicas - FMRP, USP), de acordo com o Processo HCRP $\mathrm{n}^{\mathrm{o}}$ $12665 / 2006$.

\section{COLETA E CONSERVAÇÃO DO MATERIAL}

A coleta dos dados demográficos, censitários e amostras de sangue nas comunidades da CL e RV foi realizada no período de agosto de 1994 até novembro de 1999, pelo grupo de pesquisa do LAPOGE, do qual fez parte a Autora.

Foram feitas visitas em casas, escolas e postos de saúde das comunidades e a coleta só ocorreu após o consentimento de cada indivíduo, dando-se a ele a oportunidade de negar a sua participação sem qualquer prejuízo ou restrição a exames médicos e tratamento. Durante as visitas foram preenchidos questionários com dados individuais e familiais das pessoas residentes nas comunidades.

$\mathrm{O}$ acesso a CL deu-se por barcas da prefeitura de Florianópolis, ou da cooperativa dos moradores, que saíam periodicamente do trapiche da Lagoa em direção à Costa em trajeto com duração de cerca de 50 minutos.

Para RV, o transporte foi feito de carro e as amostras, em sua maioria, foram conseguidas no posto de saúde. Também foram feitas visitas a escolas e ao centro 
comunitário. Para completar a doação espontânea, 42 amostras foram conseguidas no Laboratório Menino Deus, localizado no distrito de Ingleses do Rio Vermelho (36 km do centro da cidade e $6 \mathrm{~km}$ de RV), onde os habitantes costumam fazer exames de sangue de rotina médica. Estas amostras foram gentilmente fornecidas pelo Dr. Marcos Ludwig, embora não nos pudesse fornecer outros dados individuais, além de sexo e idade.

As amostras de sangue foram coletadas por punção venosa com seringa e agulha descartáveis, contendo EDTA 5\%. Após a coleta, o material foi mantido em recipiente contendo gelo até ser transportado ao laboratório, onde ocorreu a separação do plasma, dos leucócitos e glicerolização das hemácias.

A amostra da CL consiste de 130 indivíduos, de ambos os sexos, com idade de 1 a 86 anos. A de RV é composta por 181 indivíduos, entre homens e mulheres, na faixa etária entre 1 e 72 anos. A amostra do HMOSC é de 100 indivíduos doadores de sangue. Porém estes números variaram para cada locus, a depender da amplificação e quantidade disponível de cada amostra.

\section{CONSERVAÇÃO DO MATERIAL}

As amostras de sangue foram submetidas à centrifugação e três frações foram separadas e estocadas a $-20^{\circ} \mathrm{C}$ : o sobrenadante (plasma), o anel leucocitário (com um pouco de hemácias e plasma) e parte das hemácias (glicerolizadas em solução de glicerol a 40\%; MOLLISON, 1972). Posteriormente foi realizada a extração do DNA utilizado no presente trabalho a partir do anel leucocitário. 


\section{MARCADORES GENÉTICOS INVESTIGADOS}

\section{- Marcadores ligados ao cromossomo $Y$}

Para este trabalho foi analisado um conjunto de seis loci STRs ligados ao cromossomo Y: DYS385a/b; DYS389I e II; DYS438 e DYS439 (Tabela1), com o objetivo de ampliar a análise de haplótipos previamente descrita para cinco loci STRs (DYS19, DYS390, DYS391, DYS392 e DYS393; MUNIZ, 2003). Desta forma completando o que é chamado de haplótipo estendido do cromossomo Y. O haplótipo mínimo se refere a mesma seqüência de locus, retirando os loci DYS438 e DYS439.

Tabela 1: Localização citogenética, núcleo de repetição, seqüência dos primers, tamanho do fragmento e alelos descritos para os loci ligados ao cromossomo Y analisados no presente trabalho.

\begin{tabular}{|c|c|c|c|c|c|}
\hline Loci & Localização & Repetição $^{\mathbf{a}}$ & Seqüência primers (5’-3’) & $\begin{array}{c}\operatorname{tamanho} \\
\text { (pb) }\end{array}$ & Alelos $^{\text {a }}$ \\
\hline \multirow[t]{2}{*}{ DYS385 a/b } & Yq11. 23 & {$[\mathrm{GAAA}]_{\mathrm{n}}$} & AGCATGGGTGACAGAGCTA & $242-326$ & 22 \\
\hline & & & GCCAATTACATAGTCCTCCTTTC & & $(7-24,28)^{*}$ \\
\hline \multirow[t]{2}{*}{ DYS389 I } & Yq11. 21 & {$[\mathrm{TCTG}]_{\mathrm{q}}$} & CCAACTCTCATCTGTATTATCTATG & $143-175$ & 9 \\
\hline & & {$[\mathrm{TCTA}]_{\mathrm{r}}$} & GTTATCCCTGAGTAGTAGAAGAATG & & $(9-17)$ \\
\hline \multirow[t]{2}{*}{ DYS398 II } & Yq11. 21 & {$[\mathrm{TCTG}]_{\mathrm{n}}$} & & $255-295$ & 11 \\
\hline & & $\begin{array}{l}{[\text { TCTA }]_{\mathrm{p}}} \\
{[\text { TCTG }]_{\mathrm{q}}} \\
{[\text { TCTA }]_{\mathrm{r}}}\end{array}$ & & & $(24-34)^{\#}$ \\
\hline \multirow[t]{2}{*}{ DYS438 } & Yq11.21 & {$[\text { TTTTC }]_{n}$} & CCAAAATTAGTGGGGAATAGTTG & $300-340$ & 9 \\
\hline & & & GATCACCCAGGGTCTGGAGTT & & $(6-14)$ \\
\hline \multirow[t]{2}{*}{ DYS439 } & Yq11. 21 & {$[\mathrm{GATA}]_{\mathrm{n}}$} & 'TCGAGTTGTTATGGTTTTAGGTCT & $210-230$ & 6 \\
\hline & & & GTGGCTTGGAATTCTTTTACCC & & $(09-14)^{+}$ \\
\hline
\end{tabular}

a - Tamanho do alelo - o número inteiro refere-se ao número de alelos já descritos e os números entre parênteses referem-se ao número de repetições do menor alelo e do maior alelo, podendo-se verificar então a presença de alelos intermediários, isto é com repetições incompletas anotados com ${ }^{*}$. A anotação \# no DYS389II indica que há descrito na literatura alelos de mesmo tamanho, mas com seqüências diferentes. E a anotação + para o DYS439 indica que há na literatura inconsistência com a nomenclatura, havendo três formas diferentes descritas, aqui utilizamos a de AYUB et al. (2000) que utilize somente o número da repetição variável.

Referências primers: BUTLER et al., 2002 e http://www.cstl.nist.gov/div831/strbase/kits/Yfiler.htm (Acessado em 09/01/2008).

Os loci ligados ao cromossomo Y analisados são microssatélites (Figura 4), quatro são tetranucleotídeos: DYS385 a/b; DYS389I e II, DYS439 e apenas um pentanucleotídeo: DYS438. 


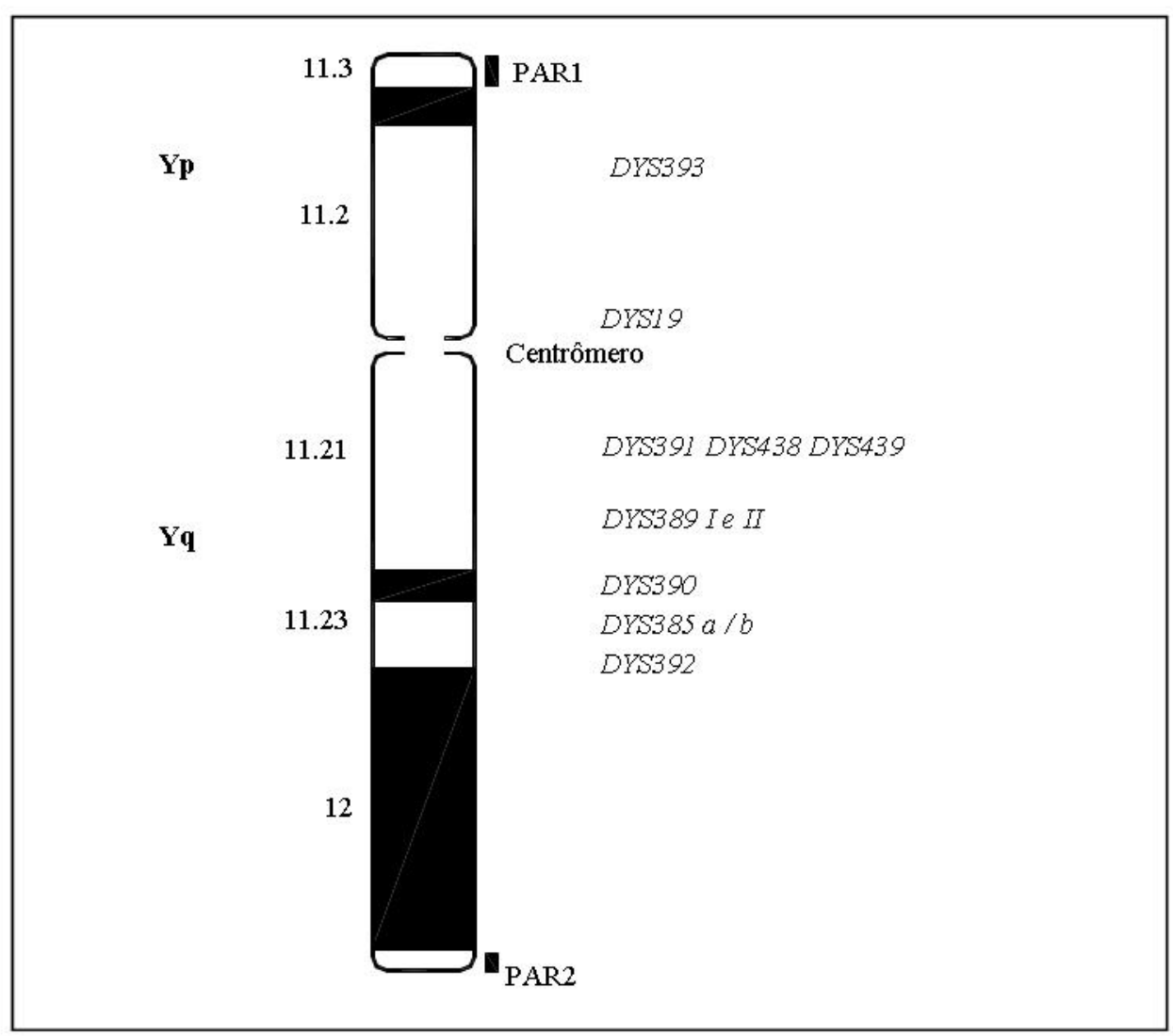

Figura 4: Localização cromossômica aproximada dos loci de STRs ligados ao cromossomo Y que compõe o haplótipo estendido (a partir de informações do site http://www.yhrd.org/index.html - Acessado em 09/01/2008)

Os loci DYS385a e DYS385b e DYS389II e DYS389II são amplificados pelo mesmo par de primers pois tratam-se de duplicação de um mesmo gene. Para o primeiro caso (DYS385a/b), os fragmentos amplificados nos dois loci apresentam exatamente os mesmos tamanhos, ficando impossível identificar a que a locus pertence o alelo identificado. Sendo assim é feita a leitura do haplótipo, mas sem a identificação da seqüência correta. Por exemplo, se o fenótipo 14/15 corresponde aos genótipos 14,15 ou 15,14 . No segundo caso (DYS389II e II) os fragmentos amplificados apresentam tamanhos diferentes, portanto sendo possível a identificação dos alelos por locus. 


\section{- AIMs analisados}

Neste trabalho foram analisados oito AIMs, seis (FY-Null, RB2300, LPL, AT3, Sb19.3 e APO) com valores de $\delta>30 \%$ entre Africanos e Europeus ou Ameríndios (PARRA et al., 1998) e dois (PV92 e CYP1A1*2C ) com $\delta>30 \%$ entre Ameríndios e Africanos ou Europeus (SHRIVER et al., 2003; LUIZON et al., 2008a; Tabela 2).

Os primers e enzimas de restrição, a localização citogenética e tamanho dos fragmentos dos AIMs analisados estão relacionados na Tabela 2.

Tabela 2: Localização citogenética, enzimas de restrição, seqüência dos primers e condições de PCR dos oito AIMs analisados.

\begin{tabular}{|c|c|c|c|c|}
\hline locus & Tipo $^{a}$ & Localização & Seqüência dos Primers (5’-3’) & $\begin{array}{c}\text { Alelo e Tamanho } \\
\text { dos fragmentos (pb) }\end{array}$ \\
\hline FY-Null & $\begin{array}{l}\text { SNP } \\
(\text { StyI })\end{array}$ & $1 \mathrm{q} 23.2$ & AGGCTTGTGCAGGCAGTG & $\begin{array}{l}1: 82,77 \text { e } 62 \\
2: 82,65 \text { e } 62\end{array}$ \\
\hline AT3-I/D & $\begin{array}{l}\text { InDel } \\
(76 b p)\end{array}$ & 1q25.1 & $\begin{array}{l}\text { GGCATAGGGATAAGGGACT } \\
\text { CCACAGGTGTAACATTGTGT }\end{array}$ & $\begin{array}{l}1: 496 \\
2: 572\end{array}$ \\
\hline LPL & $\begin{array}{l}\text { SNP } \\
(P v u I I)\end{array}$ & $8 \mathrm{p} 21.3$ & $\begin{array}{l}\text { GAGATAGTGTGATCTGAGGC } \\
\text { AGGCTTCACTCATCCGTGCCTCC }\end{array}$ & $\begin{array}{l}1: 319 \\
2: 161 \text { e } 158\end{array}$ \\
\hline RB2300 & $\begin{array}{c}\mathrm{SNP} \\
(\mathrm{BamHI})\end{array}$ & $13 q 14.2$ & $\begin{array}{l}\text { TTATGCTGCTTTAGACTCTTGTC } \\
\text { CAGGACAGCGGCCCGGAG } \\
\text { CTGCAGACGCTCCGCCGT }\end{array}$ & $\begin{array}{l}1: 180 \\
2: 130 \text { e } 50\end{array}$ \\
\hline Sb19.3 & $\begin{array}{l}\text { Inserção } \\
\text { Alu }\end{array}$ & $19 \mathrm{p} 12$ & $\begin{array}{l}\text { TCTAGCCCCAGATTTATGGTAACTG } \\
\text { AAGCACAATTGGTTATTTTCTGAC }\end{array}$ & $\begin{array}{l}1: \sim 450 \\
2: \sim 150\end{array}$ \\
\hline APO & $\begin{array}{l}\text { Inserção } \\
\text { Alu }\end{array}$ & $11 \mathrm{q} 23$ & $\begin{array}{l}\text { AAGTGCTGTAGGCCATTTAGATTAG } \\
\text { AGTCTTCGATGACAGCGTATACAGA }\end{array}$ & $\begin{array}{l}1: \sim 450 \\
2: \sim 150\end{array}$ \\
\hline PV92 & $\begin{array}{l}\text { Inserção } \\
\text { Alu }\end{array}$ & $16 \mathrm{q} 23.3$ & AACTGGGAAAATTTGAAGAGAAAGT & $\begin{array}{l}1: \sim 450 \\
2: \sim 150\end{array}$ \\
\hline CYP1A1 & $\begin{array}{c}\text { SNP } \\
(B s r D I)\end{array}$ & $15 q 22$ & $\begin{array}{l}\text { TGAGTTCTCAACTCCTGTGTGTTAG } \\
\text { СTGTCTCССТCTGGTTACAGGAAGC } \\
\text { TTCCACCCGTTGCAGGCAGGATAGCC }\end{array}$ & $\begin{array}{l}1: \sim 200 \\
2: \sim 150\end{array}$ \\
\hline
\end{tabular}

a - As enzimas de restrição para a detecção dos SNPs estão entre parênteses. 


\section{ANÁLISE LABORATORIAL}

\section{EXTRAÇÃO DO DNA GENÔMICO}

\section{- Reagentes e Soluções:}

\section{Detergente Nonidet (polyethoxyethanol)}

\section{Triton X}

Tween 20

Tampão de lise de eritrócitos: Tris/ $\mathrm{HCl} 0,01 \mathrm{M} \mathrm{pH}$ 7,6; sacarose 0,32 M; $\mathrm{MgCl}$ 5,0 $\mathrm{mM}$; e Triton X-100 1\%

Tampão de lise de leucócitos: Tris/ $\mathrm{HCl}$ 0,01M pH 8,5; $\mathrm{KCl} 50$ mM; $\mathrm{MgCl} 2$ 2,5 mM; NP-40 0,45\%; Tween 20 - 0,45\%

\section{Proteinase K (10 $\mathrm{mg} / \mathrm{mL})$}

\section{- Procedimento:}

A extração de DNA foi realizada a partir de uma adaptação ao método de HIGUCHI (1989). Aproximadamente $300 \mu \mathrm{L}$ de sangue total foi colocada em um microtubo de polipropileno de 1,5 mL (tipo eppendorf), utilizando-se uma micropipeta e ponteiras estéreis. Em seguida, adicionou-se 1,0 $\mathrm{mL}$ de tampão de lise de eritrócitos a cada microtubo. Homogeneiza-se a mistura e centrifuga-se o conteúdo dos microtubos a 12.000 giros durante 2 minutos. Retirou-se o sobrenadante com o auxílio de um sugador, e acrescentou-se, novamente, 1,0 $\mathrm{mL}$ de tampão de lise de eritrócitos ao precipitado avermelhado. Homogeneizou-se e centrifugou-se cada microtubo novamente. Estes procedimentos foram repetidos até que o precipitado apresentasse cor branca (de 3-4 repetições), indicando a presença de glóbulos brancos (leucócitos) e a ausência de hemácias.

Quando o precipitado adquiriu esta aparência branca, retirou-se o sobrenadante, suspendeu-se o precipitado em $300 \mu \mathrm{L}$ de tampão de lise de leucócitos, e adicionou-se $5 \mu \mathrm{L}$ de Proteinase K em cada microtubo. 
Terminadas estas etapas da extração, as amostras foram colocadas em uma estufa a $65^{\circ} \mathrm{C}$ por um período de 1 hora e, em seguida, em uma estufa a $37^{\circ} \mathrm{C}$ por um período de aproximadamente 12 horas. Por fim, as amostras foram submetidas a um passo de desnaturação da Proteinase $\mathrm{K}\left(94^{\circ} \mathrm{C}\right.$ por $\left.10 \mathrm{~min}\right)$ e então armazenadas em um refrigerador com temperatura aproximada de $-4^{\circ} \mathrm{C}$.

\section{REAÇÃO EM CADEIA DA POLIMERASE (PCR)}

\section{- Reagentes e Soluções:}

DNA polimerase (Taq): $1 \mathrm{U} / \mu \mathrm{L}$ de tampão de estocagem (BIOTOOLS - B \& M Labs, AS)

Tampão de estocagem da DNA polimerase: $10 \mathrm{mM}$ de Tris/ $\mathrm{HCl}(\mathrm{pH} 8,0), 50 \mathrm{mM}$ $\mathrm{KCl}, 1 \mathrm{mM}$ EDTA, 01\% Triton $\mathrm{x}-100,50 \%$ de glicerol (BIOTOOLS - B \& M Labs, AS)

dNTP solução estoque: quatro soluções separadas de $100 \mathrm{mM}$ de cada base (dATP, dCTP, dGTP, dTTP), pH 8,3 (BIOTOOLS - B \& M Labs, AS)

dNTP solução trabalho $(\mathbf{5} \mathbf{~ m M})$ : obtida diluindo-se com água a solução estoque (100mM) de cada dNTP para uma solução única de concentração 5 mM $(160 \mu \mathrm{L}$ de água de MiliQ autoclavada mais $10 \mu \mathrm{L}$ da solução estoque de cada dNTP)

Iniciadores (Primers) específicos - solução estoque (50 $\mu \mathbf{M})$ : os primers liofilizados (Bio-Synthesis) A e B específicos para cada locus foram diluídos em água autoclavada, e estocados separadamente.

Iniciadores (Primers) - solução trabalho (2,5 $\mu \mathbf{M}): 10 \mu \mathrm{L}$ do primer $\mathrm{A}, 10 \mu \mathrm{L}$ do primer B (solução estoque, $50 \mu \mathrm{M}$ ) e $180 \mu \mathrm{L}$ de água auto-clavada

Tampão PCR livre de $\mathbf{M g C l}_{2}$ : Tris/HCl 75 mM pH 9.0; $\mathrm{KCl} 50 \mathrm{mM}$; $\left(\mathrm{NH}_{4}\right) 2 \mathrm{SO}_{4} 20$ mM. (BIOTOOLS - B \& M Labs, AS).

$\mathbf{M g C l}_{2}$ : Concentração de $50 \mathrm{mM}$ (BIOTOOLS - B \& M Labs, AS).

Dimethyl Sulfoxide (DMSO) 10\%

\section{- Procedimento:}

Os ensaios da PCR foram realizados em um volume total de $25 \mu \mathrm{L}$. Todos os reagentes (Tampão de PCR livre de cloreto, dNTP, primers - solução trabalho, $\mathrm{MgCl}_{2}$ e a Taq - DNA polimerase), com exceção do DNA, foram misturados em quantidade específica para 
cada locus (Tabela 3) em um único tubo (mistura de reação) para garantir a homogeneidade das reações. As seqüências de todos os primers estão na Tabela 1.

Os STRs ligados ao cromossomo Y foram todos amplificados em apenas duas reações chamadas de multiplex, onde mais de um locus é amplificado simultaneamente: uma reação contendo os primers do DYS 385 a/b e do DYS439 e outra contendo os primers do DYS 438, DYS389 I e II (Tabela 3).

Tabela 3: Condições de PCR para os loci analisados no presente trabalho (quantidade para 1 reação).

\begin{tabular}{|c|c|c|c|c|c|c|c|}
\hline \multicolumn{8}{|c|}{ Quantidade em $\mu$ l suficiente para uma reação } \\
\hline & Locus & Água & $\begin{array}{l}\text { Tampão } \\
\text { livre de } \\
\text { cloreto }\end{array}$ & $\begin{array}{c}\text { dNTP } \\
(5 \mathrm{mM})\end{array}$ & $\begin{array}{c}\text { Primers (solução } \\
\text { trabalho) }\end{array}$ & $\begin{array}{c}\mathrm{MgCl}_{2} \\
(50 \mathrm{mM})\end{array}$ & TAQ \\
\hline \multirow{5}{*}{ 齐 } & DYS385 a/b & 14,85 & 2,50 & 0,25 & 1,00 (DYS385) & 1,00 & 0,40 \\
\hline & DYS439 & & & & 1,00 (DYS439) & & \\
\hline & DYS389 I & 11,75 & 2,50 & 0,25 & 4,00 (DYS389I e II) & 1,00 & 0,50 \\
\hline & DYS389 II & & & & 1,00 (DYS438) & & \\
\hline & DYS438 & & & & & & \\
\hline \multirow{8}{*}{ 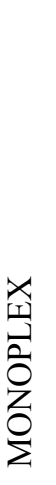 } & FY-Null & 13,75 & 2,5 & 1,0 & 0,25 & 1,5 & 0,25 \\
\hline & RB2300* & 10,75 & 2,5 & 0,75 & 0,25 & 3,0 & 0,25 \\
\hline & LPL & 13 & 2,5 & 1,0 & 0,25 & 3,0 & 0,25 \\
\hline & AT3 & 12,75 & 2,5 & 1,0 & 0,25 & 3,0 & 0,50 \\
\hline & $\mathrm{Sb} 19.3$ & 13 & 2,5 & 1,0 & 0,25 & 3,0 & 0,25 \\
\hline & APO & 13 & 2,5 & 1,0 & 0,25 & 3,0 & 0,25 \\
\hline & PV92 & 13 & 2,5 & 1,0 & 0,25 & 3,0 & 0,25 \\
\hline & CYP1A1 & 13 & 2,5 & 1,0 & 0,25 & 3,0 & 0,25 \\
\hline
\end{tabular}

* Para a amplificação do RB2300 é preciso adicionar ao mix 2,5 $\mu$ de DMSO por reação.

Em cada microtubo de $0,5 \mathrm{~mL}$ ou em cada tubo de $0,2 \mathrm{~mL}$ da placa de 96 tubos para PCR, foram pipetados $4 \mu \mathrm{L}$ do DNA genômico, previamente extraído. Para cada análise foi usado um controle negativo, contendo água no lugar do DNA genômico. Em cada microtubo, sob a amostra, foram pipetados $21 \mu \mathrm{L}$ da mistura de reação. Quando foram utilizados os 
termocicladores MJ Research (Inc PTC $-100^{\mathrm{TM}}$ ) e, consequentemente, microtubos de 0,5 mL, uma gota de óleo mineral foi adicionada para evitar a evaporação da mistura de reação. Este procedimento não foi necessário quando da utilização dos termocicladores Techne Genius ou GeneAmp $^{\circledR}$ PCR system 9700 (Applied Biosystems), pois estes possuem tampas hermeticamente fechadas. Foram nestes termocicladores que as placas de PCR foram utilizadas ao invés dos tubos. A este passo seguiu-se o programa do termociclador correspondente ao locus (listado a baixo). Após o término da reação o produto da PCR foi guardado em geladeira $\left(4 C^{\circ}\right)$ até sua utilização.

\section{- Programas utilizados:}

\section{STRs Y:}

1 ciclo: $95^{\circ} \mathrm{C}$ por 10 minutos;

28 ciclos: $94^{\circ} \mathrm{C}$ por 1 minuto, $55^{\circ} \mathrm{C}$ por 1 minuto, $72^{\circ} \mathrm{C}$ por 1 minuto;

1 ciclo: $60^{\circ} \mathrm{C}$ por 45 minutos, $20^{\circ} \mathrm{C}$ indefinidamente.

\section{FY-Null, AT3 e CYP1A1:}

1 ciclo: $94^{\circ} \mathrm{C}$ por 5 minutos;

30 ciclos: $94^{\circ} \mathrm{C}$ por 30 segundos, $55^{\circ} \mathrm{C}$ por 30 segundos, $72^{\circ} \mathrm{C}$ por 30 segundos (FY-Null e CYP1A1) e 1 minuto (AT3);

1 ciclo: $72^{\circ} \mathrm{C}$ por 5 minutos, $20^{\circ} \mathrm{C}$ indefinidamente.

\section{LPL e RB2300:}

1 ciclo: $94^{\circ} \mathrm{C}$ por 5 minutos;

30 ciclos: $94^{\circ} \mathrm{C}$ por 30 segundos, $60^{\circ} \mathrm{C}$ por 30 segundos, $72^{\circ} \mathrm{C}$ por 30 segundos (FY-Null) e 1 minuto (AT3);

1 ciclo: $72^{\circ} \mathrm{C}$ por 5 minutos, $20^{\circ} \mathrm{C}$ indefinidamente.

\section{Sb19.3, APO e PV92:}

1 ciclo: $94^{\circ} \mathrm{C}$ por 5 minutos;

30 ciclos: $94^{\circ} \mathrm{C}$ por 1 minuto, $58^{\circ} \mathrm{C}$ por 2 minutos (Sb19.3 e PV92), $55^{\circ}$ por 2 minutos (APO), $72^{\circ} \mathrm{C}$ por 2 minutos;

1 ciclo: $72^{\circ} \mathrm{C}$ por 5 minutos, $20^{\circ} \mathrm{C}$ indefinidamente.

\section{REAÇÃO DE RESTRIÇÃO}

Para a detecção dos SNPs analisados no presente estudo (FY-Null, RB2300, LPL e CYP1A1) foi utilizada a técnica de PCR-RFLP. Esta consiste basicamente de um ensaio onde 
o produto da PCR é submetido à ação de endonucleases de restrição. Os primers utilizados na PCR flanqueiam a região do gene que contém, ou não, o sítio de restrição específico da enzima utilizada na reação de restrição para cada locus (Tabela 2).

O indivíduo pode ser homozigoto para a presença do sítio de restrição da enzima (genótipo $* 2 / * 2$ ), heterozigoto (genótipo $* 1 / * 2$ ), ou homozigoto para a ausência do sítio de restrição (genótipo *1/*1).

A reação de restrição foi feita em microtubos tipo eppendorf de $0,5 \mathrm{~mL}$ para cada amostra, contendo $7 \mu \mathrm{L}$ de DNA previamente amplificado. O controle de leitura é o DNA amplificado de um indivíduo de genótipo conhecido.

Em microtubos tipo eppendorf de 1,5 mL é preparada a mistura de Reação de Restrição (Tabela 4), onde o volume de cada componente utilizado deve ser multiplicado pelo número de amostras a serem utilizadas na reação.

Tabela 4: Condições de Reação de Restrição para os SNPs analisados (quantidade em $\mu \mathrm{L}$ para 1 reação).

\begin{tabular}{lllllll}
\hline \hline \multicolumn{1}{c}{ Locus } & Água & Tampão $^{*}$ & BSA & Enzima de restrição & Total & T $^{\mathbf{0}} \mathbf{C}(\mathbf{3} \mathbf{~ h})$ \\
\hline \hline FY-Null & 5,5 & 1 & 0,1 & $0,4(4 \mathrm{U})$ & 7 & 37 \\
RB2300* & 3 & 1 & 0,1 & $0,4(4 \mathrm{U})$ & 4,5 & 37 \\
LPL & 3 & 1 & 0,1 & $0,4(4 \mathrm{U})$ & 4,5 & 37 \\
CYP1A1 & 6,4 & 1 & 0,1 & $0,5(5 \mathrm{U})$ & 8 & 65 \\
\hline \hline
\end{tabular}

* tampões comerciais com condições de pH e salinidade ótimas para a atividade das respectivas enzimas.

A mistura de Reação de Restrição é distribuída em cada eppendorf com o auxílio de uma micropipeta e ponteiras estéreis e são adicionados $7 \mu \mathrm{L}$ de DNA previamente amplificado de cada indivíduo. Estes eppendorf são então submetidos à temperatura e tempo de atividade específica para cada enzima de restrição utilizada (Tabela 4). 


\section{ANÁLISE DO PRODUTO AMPLIFICADO}

O produto amplificado foi separado por eletroforese em géis de poliacrilamida desnaturantes ou não-desnaturantes.

\section{- Reagentes e Soluções:}

TEMED: tetrametiletilenodiamina (Pharmacia Biotech).

Formamida

Solução de acrilamida/bis-acrilamida (29:1): $29 \mathrm{~g}$ de acrilamida; $1 \mathrm{~g}$ de bisacrilamida diluídas em $100 \mathrm{~mL} \mathrm{H}_{2} \mathrm{O}$.

Solução de EDTA pH 8,0: $186 \mathrm{~g}$ de EDTA; 11 de $\mathrm{H}_{2} \mathrm{O}$. Acertar o $\mathrm{pH}$ com pastilhas de hidróxido de sódio $(\mathrm{NaOH})$.

Solução saturada de Persulfato de potássio: $650 \mathrm{mg}$ de persulfato de potássio; 6,5 $\mathrm{mL}$ de $\mathrm{H}_{2} \mathrm{O}$.

Tampão TBE 10X (0,9M) pH 8,0: $108 \mathrm{~g}$ de Tris (PM=121,1); $53 \mathrm{~g}$ ácido bórico; 40 $\mathrm{mL}$ de solução de EDTA; $\mathrm{H}_{2} \mathrm{O}$ qsp 1L.

Tampão TBE cubas (1X): $100 \mathrm{~mL}$ do tampão TBE (10X); 900 mL $\mathrm{H}_{2} \mathrm{O}$.

Tampão de amostra (Loadding buffer): $900 \mu \mathrm{L}$ de brofenol; $900 \mu \mathrm{L}$ xilenocianol; $900 \mu \mathrm{L}$ TBE; 4,5 mL Ficol 30\% diluído em $\mathrm{H}_{2} \mathrm{O} ; 1,8 \mathrm{~mL}$ EDTA 0,5 M pH 8,0; 3,6 g sacarose. Misturar tudo até a dissolução completa da sacarose.

Tampão de amostra desnaturante: $300 \mu \mathrm{l}$ de tampão de amostra; $900 \mu \mathrm{L}$ formamida.

Gel desnaturante 10\%: 9,6 $\mathrm{g}$ uréia; 9,743 mL de $\mathrm{H}_{2} \mathrm{O}$; 6,667 mL solução de bisacrilamida; $2 \mathrm{~mL}$ TBE (10x); $15 \mu \mathrm{L}$ TEMED; $300 \mu \mathrm{L}$ Solução de persulfato de potássio.

Gel não desnaturante 6\%: $1,4 \mathrm{~mL}$ de glicerol, $12,4 \mathrm{~mL}$ de $\mathrm{H}_{2} \mathrm{O} ; 4 \mathrm{~mL}$ solução de bis-acrilamida; $2 \mathrm{~mL}$ TBE (10x); $15 \mu \mathrm{L}$ TEMED; $300 \mu \mathrm{L}$ Solução de persulfato de potássio.

Gel não desnaturante 10\%: 1,4 mL de glicerol, 12,390 mL de $\mathrm{H}_{2} \mathrm{O} ; 4 \mathrm{~mL}$ solução de bis-acrilamida; $2 \mathrm{~mL}$ TBE (10x); $15 \mu \mathrm{L}$ TEMED; $300 \mu \mathrm{L}$ Solução de persulfato de potássio.

\section{- Procedimento:}

Para os STRs ligados ao cromossomo Y o produto amplificado foi separados por eletroforese em géis de poliacrilamida a 10\% (PAGE) desnaturantes. Estes foram feitos dissolvendo a uréia com a solução de acrilamida/bisacrilamida e água em "banho Maria" a $50^{\circ} \mathrm{C}$, antes da adição do TBE, adicionado apenas após o resfriamento da solução. 
Para o AIMs os produtos amplificados e oriundos das reações de restrição foram separados por eletroforese em PAGE a 6\% e não-desnaturante, exceto para o FY-Null, para o qual foi utilizado PAGE a 10\% não-desnaturante.

Os catalizadores da reação de polimerização do gel, TEMED e persulfato de potássio foram adicionados à mistura do gel imediatamente antes de vertê-las em um cassete previamente montado, composto de duas placas de vidro separadas por espaçadores de teflon e presas com grampos. O tamanho das placas é determinado de acordo com o tipo de marcador (Tabela 5). Logo após, um pente de teflon foi colocado na borda superior, formando poços no gel, onde posteriormente foram aplicadas as amostras de DNA amplificado por PCR ou oriundos das Reações de Restrição. Aguardou-se a polimerização por no mínimo 30 minutos.

Tabela 5: Condições específicas para eletroforese de cada locus analisado no presente trabalho.

\begin{tabular}{|c|c|c|c|c|}
\hline Loci & Gel & $\begin{array}{c}\text { Tamanho placa } \\
(\mathbf{c m})\end{array}$ & Voltagem & Tempo (h) \\
\hline $\begin{array}{l}\text { DYS385 a/b } \\
\text { DYS439 }\end{array}$ & $10 \%$ desnaturante & $22,0 \times 17,0$ & $20 \mathrm{~mA}$ por gel & $\begin{array}{l}40^{\prime} \text { após a saída do } 2^{\circ} \\
\text { corante }(\sim 2: 40 \mathrm{~h})\end{array}$ \\
\hline $\begin{array}{l}\text { DYS389 I } \\
\text { DYS389 II }\end{array}$ & & $14,5 \times 16,5$ & & $\begin{array}{c}40^{\prime} \text { após a saída do } 2^{\circ} \\
\text { corante }(\sim 3: 40 \mathrm{~h})\end{array}$ \\
\hline DYS438 & & & & \\
\hline FY-Null & $10 \%$ não desnaturante & $12,0 \times 16,5$ & $200 \mathrm{~V}$ & $1: 30 \mathrm{~h}$ \\
\hline $\begin{array}{l}\text { RB2300, } \\
\text { LPL, AT3, } \\
\text { Sb19.3, } \\
\text { APO, PV92 } \\
\text { e CYP1A1 }\end{array}$ & $6 \%$ não desnaturante & & & $1: 00 \mathrm{~h}$ \\
\hline
\end{tabular}

Após a polimerização do gel o pente foi retirado e os poços foram lavados com água. O gel polimerizado foi montado em cuba de eletroforese vertical contendo tampão TBE cubas (1x), em ambos os pólos (porção superior e inferior). Esta cuba foi conectada a uma fonte de voltagem, Amershan Pharmacia Biotech (EPS 1001), ajustada à voltagem ou corrente 
constante necessária para uma boa separação dos fragmentos amplificados (Tabela 5). Foi feita uma pré-corrida de pelo menos 15 minutos, onde as cubas com os géis foram ligados às fontes antes da aplicação das amostras e submetidas às condições de eletroforese. A fonte foi desligada e as amostras foram aplicadas nos poços.

Nos loci em que os fragmentos amplificados precisam ser submetidos a condições desnaturantes, STRs ligados ao cromossomo Y, antes da aplicação das amostras no gel foi necessário um tratamento prévio com formamida, que auxilia no processo de desnaturação das amostras. Para isso foram colocados $7 \mu \mathrm{L}$ de Tampão de Amostra desnaturante em um tubo eppendorf, junto com $3 \mu \mathrm{L}$ do produto amplificado. Estes tubos foram aquecidos a $94^{\circ} \mathrm{C}$ por 15 minutos e colocados imediatamente em banho de gelo (tratamento desnaturante), seguindo-se a aplicação no gel de 10\% (Tabela 5).

Para os AIMs não foi necessário tratamento desnaturante, sendo aplicado $7 \mu \mathrm{L}$ de amostra de DNA amplificado oriundo da PCR ou da Reação de Restrição, juntamente com 4 $\mu \mathrm{L}$ de Tampão amostra, em géis não desnaturantes $6 \%$ ou 10\% (Tabela 5). Para os AIMs que são SNPs (FY, RB, LPL e CYP1A1) uma eletroforese prévia era realizada, no intuito de confirmar a amplificação positiva do fragmento de interesse, antes de submetê-lo à ação da enzima de restrição adequada (Tabela 2).

Após a aplicação das amostras as fontes foram novamente ligadas e a eletroforese prosseguiu da maneira descrita na Tabela 5. Com o término da corrida eletroforética, o gel foi retirado cuidadosamente das placas de vidro e submetido aos procedimentos de coloração e secagem. 


\section{COLORAÇÃO COM NITRATO DE PRATA E SECAGEM DO GEL}

- Reagentes e soluções:

Solução de nitrato de prata: $10 \mathrm{~g}$ nitrato de prata; $100 \mathrm{~mL}$ de $\mathrm{H}_{2} \mathrm{O}$. Dissolver a prata em uma parte da água e depois completar com o restante, manter a solução ao abrigo da luz (volume final $100 \mathrm{~mL}$ ).

Solução fixadora: $160 \mathrm{~mL}$ etanol (PA) e $7 \mathrm{~mL}$ de ácido acético glacial (PA); $833 \mathrm{~mL}$ de $\mathrm{H} 2 \mathrm{O}$ (volume final $1 \mathrm{~L}$ ).

Solução reveladora: $22,5 \mathrm{~g}$ de $\mathrm{NaOH} ; 1 \mathrm{~L}$ de $\mathrm{H}_{2} \mathrm{O}$. Dissolver em um agitador o hidróxido de sódio em uma parte da água e depois completar com o restante (volume final $1 \mathrm{~L}$ ). $\mathrm{Na}$ hora da coloração adicionar $1 \mathrm{~mL}$ de formaldeído para cada $100 \mathrm{~mL}$ da solução.

\section{- Procedimento:}

Fixação: Após a retirada das placas de vidro e dos espaçadores o gel foi colocado em um recipiente de vidro contendo $100 \mathrm{~mL}$ de solução fixadora.

Impregnação com Nitrato de prata: adicionou-se $2,0 \mathrm{~mL}$ de solução de nitrato de prata, e agitou-se por 5 minutos. A solução foi então descartada e o gel lavado em água quente por cerca de 10 segundos, agitando levemente e, ao final, descartando a água.

Revelação: A solução reveladora foi despejada cuidadosamente no recipiente contendo o gel, que foi submetido à agitação por alguns minutos até que as bandas aparecessem nitidamente. A solução foi pré-aquecida em estufa a $65^{\circ} \mathrm{C}$, para facilitar a reação de coloração.

Bloqueio da reação: Após ter sido revelado, a solução reveladora foi descartada e a reação bloqueada com a lavagem direta do gel em $100 \mathrm{~mL}$ de solução fixadora.

Secagem do gel: Após a leitura, todos os géis passaram por um processo de secagem simples para que pudessem ser armazenados para análises e confirmações posteriores. Duas folhas de papel celofane foram molhadas; uma placa de vidro, com a área maior que a do gel, foi coberta com uma das folhas; o gel foi colocado sobre a placa com o celofane sem deixar bolhas; o gel foi então bem molhado e coberto com a outra folha de celofane, também com cuidado de não deixar bolhas; este gel foi deixado secando à temperatura ambiente por dois ou três dias até a secagem completa, sendo então devidamente identificado e arquivado.

\section{DETERMINAÇÃO FENOTÍPICA (NOMENCLATURA)}

Os alelos dos loci ligados ao Y foram designados segundo KAYSER (1997) e AYUB et al. (2000). Onde foi proposto que a nomenclatura dos alelos deva ser baseada no número de repetições: o número que denomina o alelo representa o número de repetições presente no 
mesmo. Por exemplo, um alelo com 10 repetições é denominado alelo *10. Da mesma forma ocorre para nomear alelos de repetição incompleta, onde o nome é composto por dois números separados por ponto, o primeiro indicando o número de repetições completas presente e o segundo indicando o número de nucleotídeo presente na repetição incompleta.

Os alelos dos STRs foram identificados por ordem crescente de tamanho, definida pela migração eletroforética. Dois padrões diferentes de leitura foram intercalados a cada 3-5 amostras de maneira que o gel sempre começa e termina com um padrão de leitura. Os alelos destes padrões foram definidos por seqüenciamento ou comparados lado a lado com amostras padrões previamente seqüenciadas.

Para os AIMs analisados no presente estudo a denominação dos alelos foi feita seguindo a convenção estabelecida em PARRA et al. (1998), onde o alelo *1 (por ex., RB*1) é o fragmento correspondente à banda de maior peso molecular observada no gel de poliacrilamida, devido à presença de uma inserção ou inserção Alu (para os loci AT3-I/D, Sb19.3, APO e PV92) ou à ausência de um sítio de restrição (para os loci FY-null, RB2300 e LPL). O alelo CYP1A1*2C é considerado aqui como um AIM (LUIZON et al., 2008b). No entanto, para simplificar seu uso durante o texto este alelo foi mencionado como CYP1A1. Um ladder (escada de peso molecular) e um controle positivo de restrição foram sempre utilizados.

Após a eletroforese e coloração do gel as amostras foram comparadas com os padrões, ladder ou controles positivos de restrição, de acordo com seu tamanho e a leitura de seus alelos foi anotada. No caso de alguma dúvida as amostras que apresentaram mesma leitura foram comparadas lado a lado em outro gel para confirmação de seus alelos. 


\section{TAMANHO AMOSTRAL}

Nos loci ligados ao cromossomo Y foram analisados em 44 homens da CL e 50 de RV e 50 para HM. Para os loci autossômicos o tamanho amostral foi de 120 indivíduos na CL e 163 indivíduos em RV e 50 para HM. O tamanho amostral para cada locus variou, pois alguns indivíduos não amplificaram ou suas amostras acabaram antes de todas as amplificações. O tamanho exato de cada amostra para cada locus é indicado nas Tabelas na medida em que os resultados são apresentados. Para análise dos haplótipos do cromossomo Y só foram considerados aqueles indivíduos que amplificaram para todos os loci 18 na CL, e 32 em RV e 20 em HM.

\section{ANÁLISE ESTATÍSTICA}

\section{- Freqüências Gênicas em Populações Ancestrais}

A partir de freqüências alélicas de populações parentais disponíveis na literatura foi possível realizar o cálculo da heterozigose e as análises de componente principal.

As freqüências gênicas utilizadas para representar as populações ancestrais, açoriana, africanas e ameríndias dos STRs ligados ao cromossomo Y: DYS385a/b, DYS389I e II, DYS 438 e DYS439 e dos AIMs: FY-Null, RB2300, LPL, AT3, Sb19.3, APO, PV92 e CYP1A1, foram as freqüências descritas na literatura. Quando haviam dados de mais de uma população foi feita asmédias, ponderadas pelos tamanhos amostrais, das freqüências.

Para os STRs ligados ao cromossomo Y, devido a disponibilidade na literatura de dados para o haplótipo completo, as populações parentais utilizadas foram açoriana (100 indivíduos do arquipélago de Açores, FERNANDES \& BREHM, 2003), africana (203 indivíduos da Guiné-Bissau, ARROYO-PARDO et al. 2005) e ameríndia (22 Kaingang e 20 
Guaranis, LEITE et al., 2008). Quando o haplótipo mínimo foi considerdo, além destas parentais um número maior de populações pôde ser usado para comparação: Portugal (PONTES et al., 2007), Espanha (MARTÍN et al., 2004), Guiné-Equatorial (ARROYOPARDO et al. 2005), Santa Catarina (CAINÉ et al., 2005), Rio Grande do Sul (LEITE et al., 2008), São Paulo (GÓIS et al., 2008) e amostras das cinco regiões brasileiras, Sul, Sudeste, Centro-oeste, Nordeste e Norte (GRATTAPAGLIA et al., 2005).

Para os AIMs a média européia ponderada foi obtida a partir das freqüências na Inglaterra, Irlanda, Alemanha (PARRA et al., 1998), Portugal (TOMÁS et al., 2002) e Espanha (dbSNP/NCBI). As freqüências alélicas de República Centro Africana, Nigéria (Benin e Ibadan) (PARRA et al., 1998), e Serra Leoa (Mende e Temne) (PARRA et al., 2001), foram tomadas para o cálculo da média ponderada Africana; e a média ponderada das freqüências alélicas dos Maias (México) e de indígenas do Sudoeste dos Estados Unidos (representados por uma amostra envolvendo os Pima, Pueblo e Cheyenne; dbSNP/NCBI) foi calculada para os indígenas da América do Norte. As freqüências destes AIMs em indígenas da Amazônia Brasileira foram obtidas em LUIZON et al. (2008a).

As estimativas de mistura obtidas com o software ADMIX também são calculadas a partir de freqüências alélicas. Entretanto, nesse caso as freqüências parentais européias para os AIMs foram representadas por Portugueses e as africanas pela freqüência observada na cidade de Santana, capital da Ilha de São Tomé (TOMÁS et al., 2002), tal como realizado por PARRA et al. (2003). Esta Ilha serviu como entreposto durante o tráfico negreiro pelo Atlântico e, por isso, possui uma população teve origem em várias regiões Africanas (TOMÁS et al., 2002).

No entanto, o cálculo do $F_{S T}$ e as análises do software Structure exigem freqüências genotípicas, que não estão disponíveis na literatura. Esta informação genotípica dos AIMs 
analisados (exceto o CYP1A1) para indivíduos da Nigéria (Africana) e da Espanha e Alemanha (Européia) foi gentilmente cedida pelo Dr. Mark David Shriver, Professor do Departamento de Antropologia da Universidade da Pennsylvania (SHRIVER, informação pessoal). Duas amostras aleatórias de 55 indivíduos para cada um daqueles grupos étnicos foram selecionadas com o uso da função aleatório no programa Excel®. Estes genótipos Africanos e Europeus foram admitidos como parentais nas comparações par a par dos valores de $F_{S T}$ e também nas análises do software STRUCTURE®.

\section{- Estimativas das freqüências alélicas e genotípicas}

Os loci autossômicos do tipo STR, SNPs e Inserções/Deleções apresentam alelos codominantes, o que permite inferir os genótipos a partir dos respectivos fenótipos. As freqüências alélicas $\left(x_{i}\right)$ e genotípicas $\left(X_{i i}\right)$ de cada locus em cada comunidade foram estimadas por contagem direta, utilizando-se o programa GENEPOP ${ }^{\circledR}$ (RAYMOND e ROUSSET, 1995a) versão 3.4 (disponível em http://wbiomed.curtin.edu.au/genepop), segundo as equações:

$$
x_{i}=\frac{2 n_{i i}+\sum n_{i j}}{2 n} \quad \text { e } \quad X_{i i}=\frac{n_{i i}}{n}
$$

Em que:

$x_{i}$ é a freqüência do alelo "i"

$X_{i i}$ é a freqüência do genótipo "ii"

$n_{i i}$ e $n_{i j}$ correspondem ao número de homozigotos e heterozigotos observados para o alelo $i$, respectivamente;

$n$ corresponde ao número de indivíduos analisados.

A comparação das distribuições das freqüências alélicas foi realizada pelo teste exato de Fisher. Todos os alelos foram comparados entre as duas comunidades. As freqüências das comunidades foram também comparadas com as freqüências de açorianos. Quando nesta 
última comparação eram obtidas diferenças significativas, as freqüências eram comparadas com as freqüências de africanos e ameríndios.

\section{- Diversidade haplotípica}

A diversidade haplotípica $(h)$, equivalente à heterozigose em dados diplóides, foi estimada considerando a freqüência dos haplótipos como definida por NEI (1987). No caso dos genomas haplóides (região não recombinante do cromossomo $\mathrm{Y}$ ), $h$ representa a probabilidade de que dois haplótipos escolhidos aleatoriamente sejam diferentes na amostra. As fórmulas da diversidade haplotípica $(h)$ e seu desvio padrão $(D P)$ são:

$$
\begin{aligned}
& h=\frac{n}{n-1}\left(1-\sum_{i=1}^{k} p_{i}^{2}\right) \\
& D P=\left\{\frac{2}{n(n-1)}\left\{2(n-2)\left[\sum p_{i}{ }^{3}-\left(\sum p_{i}{ }^{2}\right)^{2}\right]+\sum p_{i}{ }^{2}-\left(\sum p_{i}{ }^{2}\right)^{2}\right\}\right\}^{\frac{1}{2}}
\end{aligned}
$$

Em que:

$p_{i}$ é a freqüência do haplótipo $i$;

$n$ é o número de cromossomos da amostra;

$k$ é o número de haplótipos.

Os cálculos foram realizados com o programa ARLEQUIN (SCHNEIDER et al., 2000).

\section{- Análise de Variância Molecular (AMOVA)}

O Programa ARLEQUIN $®$ (SCHNEIDER et al., 2000) foi usado para estimar a diferenciação genética das populações pela análise de variância molecular (AMOVA), o que permite análises hierárquicas de três componentes da variância genética, ou seja, aquela devido a diferenças genéticas entre indivíduos dentro das populações $\left(\Phi_{S T}\right)$, entre populações dentro dos grupos $\left(\Phi_{S C}\right)$ e entre grupos $\left(\Phi_{C T}\right)$. O teste de significância dos valores de variância genética foi estimado com o uso de 10.000 permutações. 
No presente estudo foi realizada somente a diferenciação genética entre indivíduos das amostras CL, RV e HM e entre as comunidades. Isto porque quando separamos grupos (CL e RV X HM) não foram encontrados resultados significativos.

\section{- Diversidade gênica no cromossomo $Y$}

A análise de diversidade genética foi estimada usando os parâmetros $H_{S}$ (NEI, 1987) usando o programa FSTAT® 2.8 (GOUDET, 1999).

\section{Em que:}

$\boldsymbol{H}_{\boldsymbol{S}}=$ a heterozigose média dentro das populações, ou diversidade gênica;

A estimativa não-viciada da diversidade genética $\left(H_{S}\right)$ por locus e por comunidade, foi obtida de acordo com a equação 7.39 proposta por NEI (1987), utilizando-se o programa FSTAT ${ }^{\circledR} 2.8$ (GOUDET, 1999):

$$
H_{s k}=\frac{n_{k}}{n_{k}-1}\left(1-\sum p_{i k}^{2}-H_{o k} / 2 n_{k}\right)
$$

Em que:

$\boldsymbol{n}_{\boldsymbol{k}}$ é o tamanho da k-ésima amostra, $\boldsymbol{p}_{\boldsymbol{i} \boldsymbol{k}}$ é a freqüência do alelo $i$ na amostra $\boldsymbol{k}$, e $\boldsymbol{H}_{\boldsymbol{o}}$ é a proporção de heterozigotos observada na amostra da população $\boldsymbol{k}$.

\section{- Aderência ao equilíbrio de Hardy-Weinberg}

Segundo o teorema de Hardy-Weinberg, as freqüências genotípicas esperadas no equilíbrio podem ser estimadas a partir da expansão do seguinte binômio:

$$
\left(x_{i}+x_{j}\right)^{2}=x_{i}^{2}+2 x_{i} x_{j}+2 x_{j}^{2}
$$

Em que:

$x_{i}^{2}$ é a freqüência esperada dos homozigotos do alelo $i$;

$2 x_{i} x_{j}$ é a freqüência esperada do heterozigoto $i j$;

$2 x_{j}^{2}$ é a freqüência esperada dos homozigotos para o alelo $j$. 
A aderência das freqüências genotípicas observadas às proporções teóricas de HardyWeinberg foi verificada com o emprego do programa GENEPOP $®$ (RAYMOND \& ROUSSET, 1995a) versão 3.4. Foram realizados três testes baseados na hipótese nula de união aleatória dos gametas: teste exato de probabilidade, teste para detecção da deficiência e para detecção do excesso de heterozigotos.

No teste exato de probabilidade, o valor de $p$ corresponde à soma de probabilidades de todas as Tabelas com probabilidade menor ou igual ao observado. O segundo e o terceiro são testes mais sensíveis do que o de probabilidade e utilizam uma hipótese alternativa (H1) de excesso ou de deficiência de heterozigotos, respectivamente.

\section{- Associações par-a-par entre loci}

A análise de associações par-a-par entre loci foi realizada utilizado-se o programa GENEPOP ${ }^{\circledR} 3.4$ (RAYMOND \& ROUSSET, 1995a). A hipótese nula é a de que a distribuição genotípica em um locus é independente da distribuição em outro locus. Esta análise foi aplicada para verificar desvios do esperado pela regra de multiplicação entre pares de loci localizados em diferentes cromossomos. A palavra "ligação" neste caso não está relacionada com associação física entre alelos de loci de um mesmo cromossomo.

\section{- Diversidade gênica}

A diversidade gênica média $\left(\bar{H}_{S}\right)$ com o respectivo erro padrão foi calculada para cada comunidade utilizando o programa DISPAN ${ }^{\circledR}$ (OTA, 1993), conforme a equação 8.6 apresentada em NEI (1987):

$$
H=\sum_{j=i}^{r} h_{j} / r
$$


Em que $\mathrm{r}$ é o número de loci utilizados e $\mathrm{h}_{\mathrm{j}}$, de acordo com a equação 8.1 de NEI (1987), é a heterozigose esperada para cada locus na $\mathrm{j}^{\text {-ésima }}$ população, estimada por:

$$
h=1-\sum_{i=1}^{m} x_{i}^{2}
$$

Em que $m$ é o número de alelos.

Esta medida de heterozigose média é equivalente à proporção média de heterozigotos por locus em uma população com padrão de acasalamento aleatório e, também, é igual à proporção de loci heterozigotos em um indivíduo escolhido aleatoriamente. O desvio padrão desta estimativa é descrito pela seguinte equação adaptada (NEI, 1987):

$$
\left.H=\left[\sum_{j=1}^{r} h_{j}-H\right)^{2} /(r-1) r\right]^{1 / 2}
$$

\section{- Diversidade Interpopulacional (Estatísticas F)}

As estatísticas F foram obtidas como descrito por WEIR (1984), usando o software GDA® (Genetic Data Analysis Package; LEWIS \& ZAYKIN, 1997). São definidos 3 parâmetros:

$F_{I S}$ : Coeficiente de endogamia dentro de uma população (déficit de heterozigotos dentro de uma população);

$F_{I T}$ : Coeficiente de endogamia total, dado pela probabilidade de dois alelos tomados ao acaso de todo o conjunto populacional sejam idênticos por descendência (déficit de heterozigotos global); 
$F_{S T}$ : Coeficiente de endogamia em um par de populações, dado pela probabilidade de dois alelos tomados ao acaso em duas populações serem idênticos por descendência (déficit de heterozigotos entre populações).

Estes três parâmetros estão relacionados da seguinte maneira:

$$
\text { Fis }=(\text { Fit }-F s t) /(1-F s t)
$$

Para testar se os valores de $F_{S T}$ e $F_{I S}$ diferiam significativamente de zero, foi realizado o procedimento de bootstrap com 1000 replicações. Se os intervalos de confiança de 95\% e $99 \%$ assim obtidos não incluíam o zero, a estimativa foi considerada significativamente diferente de zero com $\alpha=5 \%$ ou $1 \%$, respectivamente.

\section{- Diferenciação genética das populações}

Os testes exatos para diferenciação populacional foram realizados com o uso do programa GENEPOP ${ }^{\circledR} 3.4$ (RAYMOND \& ROUSSET, 1995a). Este utiliza Tabelas de contingência $\mathrm{RxC}$ geradas automaticamente para cada locus, em que $\mathrm{R}$ é o número de populações e C é o número de alelos no locus.

Este procedimento compara cada locus em pares de populações, para determinar se existem diferenças nas freqüências alélicas e genotípicas observadas, onde a hipótese nula testada é a de que a distribuição alélica é idêntica entre as populações (RAYMOND \& ROUSSET, 1995b).

\section{- Inferência de Estrutura Populacional (STRUCTURE)}

O programa STRUCTURE® (http://pritch.bsd.uchicago.edu/structure.html) utiliza um método de agrupamento para a inferência de estrutura populacional utilizando dados 
genotípicos de marcadores não ligados, baseado no modelo desenvolvido por PRITCHARD et al. (2000).

A opção Use Pop Info Selection FLAG foi habilitada no intuito de determinar de forma mais precisa os clusters (grupos) que representam os indivíduos sabidamente pertencentes a populações consideradas parentais: Africana (55 Nigerianos), Européia (55 Espanhóis e Alemães) e Ameríndios da Amazônia Brasileira (55 indivíduos aleatoriamente selecionados dentre os 309 genotipados por LUIZON et al., 2008a). Na opção Ancestry Model foi selecionado Use Population Information. As análises foram realizadas com $\mathrm{K}=3$ como parâmetro predefinido para o número de populações assumidas como parentais, com 30.000 interações para o período burn-in e 100.000 interações adicionais para obter as estimativas dos parâmetros.

\section{- Análises de Componente Principal}

O programa MVSP ${ }^{\circledR}$ (Multivariate Statistical Package for Windows, version 3.1; http://www.kovcomp.com/mvsp/) foi utilizado para a obtenção de Análises de Componente Principal relacionando as comunidades do presente estudo com populações africanas, européias, afro-americanas e euro-americanas (PARRA et al., 1998) e também com populações Ameríndias dos EUA (dbSNP) e da Amazônia Brasileira (LUIZON et al., 2008a).

Devido ao número diferente de freqüências alélicas disponíveis na literatura para comparação, foram realizadas quatro análises: (1) com seis AIMs (FY, RB, LPL, AT3, Sb19.3 e APO); (2) adicionando-se o locus PV92 aos seis primeiros AIMs; (3) com o haplótipo estendido do cromossomo Y e (4) com o haplótipo mínimo do Y. 


\section{- Estimativas de mistura étnica}

As estimativas das proporções étnicas foram obtidas segundo o método de identidade gênica (CHAKRABORTY, 1985) e foram realizadas com o uso dos programas ADMIX® 3. Este método foi escolhido para permitir a comparação com as estimativas de mistura obtidas nas mesmas amostras (MUNIZ, 2003).

A estimativa foi realizada primeiro utilizando as freqüências nas três populações parentais admitindo-se um modelo trí́brido de mistur. Nos casos onde houve inconsistência com alguma das populações consideradas parentais, a mesma foi retirada e a estimativa foi refeita somente com as outras duas populações parentais utilizando o ADMIX 2.

Para os AIMs as freqüências de Portugueses foram utilizadas como parental européia, da cidade de Santana (Ilha de São Tomé) como parental africana (TOMÁS et al., 2002) e a freqüência média de sete aldeias da Amazônia Brasileira como parental ameríndia (LUIZON et al., 2008a).

Para os STRs-Y uma amostra da população açoriana (FERNADES \& BREHN, 2003) foi utilizada como parental européia. Como parental africana uma amostra de Guiné-Bissau (ARROYO-PARDO et al., 2005). E como ameríndia 22 Kaigangs e 20 Guaranis (LEITE et al., 2008)

Nos casos em que houve disponibilidade de mais de uma estimativa de freqüências para uma mesma população, foram utilizadas freqüências médias, ponderadas pelos tamanhos amostrais. 


\section{RESULTADOS}

\section{CROMOSSOMO Y. FREQÜÊNCIAS ALÉLICAS E DIVERSIDADE GENÉTICA}

São aqui apresentados resultados de 11 loci que compõem o haplótipo estendido do cromossomo Y (DYS19, DYS385a/b, DYS389I, DYS389II, DYS390, DYS391, DYS392, DYS393, DYS438 e DYS439). Cinco deles (DYS19, DYS390, DYS391, DYS392, DYS393) tiveram suas freqüências apresentadas anteriormente (MUNIZ 2003) nas comunidades CL e RV, mas são aqui reapresentados de forma a facilitar a análise do haplótipo estendido.

Os loci DYS385a e DYS385b tratam-se de duplicação de um mesmo gene (Material e Métodos 45p). Neste caso é impossível identificar a seqüência correta de todos os haplótipos impossibilitando a cálculo das freqüências alélicas por locus. Por esta razão estas freqüências não foram listadas na Tabela 6 , onde se descrevem as freqüências dos outros loci das amostras aqui analisadas e das populações parentais.

Tabela 6: Distribuição das freqüências alélicas de 10 Y-STRs nas comunidades analisadas (CL e RV), na amostra urbana (HM) e nas parentais açoriana (FERNANDES \& BREHN, 2003), africana (ROSA et al., 2006) e ameríndia (LEITE et al., 2008). As freqüências dos loci DYS19, DYS390, DYS391, DYS392 e DYS393 são de MUNIZ (2003).

\begin{tabular}{|c|c|c|c|c|c|c|}
\hline Locus I Alelo & CL & RV & HM & Açoriana & Ameríndia & Africana \\
\hline \multirow[t]{7}{*}{ DYS19 } & $\mathrm{n}=44$ & $\mathrm{n}=53$ & $\mathrm{n}=37$ & $\mathrm{n}=100$ & $\mathrm{n}=46$ & n=163 \\
\hline & & & 0,027 & & & \\
\hline & 0,023 & 0,075 & 0,190 & 0,140 & 0,413 & 0,030 \\
\hline & 0,705 & 0,642 & 0,459 & 0,590 & 0,348 & 0,099 \\
\hline & 0,136 & 0,151 & 0,324 & 0,220 & 0,196 & 0,465 \\
\hline & 0,114 & 0,094 & & 0,040 & 0,043 & 0,188 \\
\hline & 0,023 & 0,038 & & 0,010 & & 0,208 \\
\hline \multirow[t]{6}{*}{ DYS389I } & $\mathrm{n}=35$ & $\mathrm{n}=44$ & $\mathrm{n}=79$ & $\mathrm{n}=100$ & $\mathrm{n}=215$ & $\mathrm{n}=46$ \\
\hline & 0,029 & 0,091 & & & & 0,010 \\
\hline & & & 0,165 & 0,200 & 0,457 & 0,089 \\
\hline & 0,857 & 0,727 & 0,658 & 0,590 & 0,543 & 0,604 \\
\hline & & & 0,177 & 0,210 & & 0,277 \\
\hline & 0,114 & 0,182 & & & & 0,020 \\
\hline DYS389II & $n=34$ & $n=45$ & $n=63$ & $n=100$ & $n=210$ & $n=46$ \\
\hline 26 & & & & & 0,022 & \\
\hline
\end{tabular}




\begin{tabular}{|c|c|c|c|c|c|c|}
\hline Locus I Alelo & $\overline{C L}$ & RV & $\mathrm{HM}$ & Açoriana & Ameríndia & Africana \\
\hline 28 & 0,118 & $\overline{00,044}$ & "0,063 & 0,070 & 0,130 & 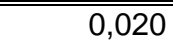 \\
\hline 29 & 0,382 & 0,556 & 0,429 & 0,590 & 0,457 & 0,178 \\
\hline 30 & 0,441 & 0,311 & 0,460 & 0,250 & 0,369 & 0,485 \\
\hline 31 & 0,059 & 0,067 & 0,016 & 0,080 & 0,022 & 0,258 \\
\hline 32 & & 0,022 & 0,016 & 0,010 & & 0,059 \\
\hline 33 & & & 0,016 & & & \\
\hline \multirow[t]{8}{*}{ DYS390 } & $n=45$ & $n=51$ & $n=34$ & $n=100$ & $n=215$ & $n=46$ \\
\hline & & 0,059 & 0,029 & 0,070 & 0,043 & 0,693 \\
\hline & 0,089 & 0,137 & & 0,080 & 0,174 & 0,050 \\
\hline & 0,333 & 0,157 & 0,265 & 0,250 & 0,783 & 0,059 \\
\hline & 0,511 & 0,510 & 0,588 & 0,440 & & 0,129 \\
\hline & & 0,039 & 0,118 & 0,140 & & 0,069 \\
\hline & 0,067 & 0,078 & & 0,020 & & \\
\hline & & 0,020 & & & & \\
\hline \multirow[t]{5}{*}{ DYS391 } & $n=45$ & $n=55$ & $n=36$ & $n=100$ & $n=215$ & $n=46$ \\
\hline & 0,200 & 0,091 & 0,056 & 0,040 & & 0,059 \\
\hline & 0,333 & 0,455 & 0,638 & 0,220 & 0,696 & 0,753 \\
\hline & 0,400 & 0,382 & 0,306 & 0,740 & 0,304 & 0,188 \\
\hline & 0,067 & 0,073 & 0,000 & & & \\
\hline \multirow[t]{7}{*}{ DYS392 } & $n=44$ & $n=44$ & $n=23$ & $n=100$ & $n=163$ & $n=46$ \\
\hline & 0,023 & 0,023 & 0,435 & 0,040 & & \\
\hline & 0,341 & 0,205 & & 0,330 & 0,087 & 0,763 \\
\hline & 0,159 & 0,159 & 0,392 & 0,060 & & 0,059 \\
\hline & 0,295 & 0,409 & 0,130 & 0,540 & 0,304 & 0,168 \\
\hline & 0,182 & 0,159 & 0,043 & 0,030 & 0,500 & 0,010 \\
\hline & & 0,045 & & & 0,109 & \\
\hline DYS393 & $n=38$ & $n=54$ & $n=37$ & $n=100$ & $n=215$ & $n=46$ \\
\hline 11 & & & & 0,030 & & \\
\hline 12 & 0,143 & 0,056 & 0,189 & 0,290 & 0,130 & 0,020 \\
\hline 13 & 0,762 & 0,759 & 0,730 & 0,560 & 0,740 & 0,445 \\
\hline 14 & 0,095 & 0,167 & 0,081 & 0,100 & 0,130 & 0,277 \\
\hline 15 & & 0,019 & & 0,020 & & 0,248 \\
\hline 16. & & & & & & 0,010 \\
\hline \multirow[t]{7}{*}{ DYS438 } & $n=41$ & $\mathrm{n}=46$ & $\begin{array}{r}\mathrm{n}=84 \\
0,071\end{array}$ & $\begin{array}{r}\mathrm{n}=100 \\
0,160\end{array}$ & $n=165$ & $n=46$ \\
\hline & & & 0,107 & 0,220 & 0,043 & 0,119 \\
\hline & 0,024 & 0,022 & 0,060 & 0,090 & 0,609 & 0,643 \\
\hline & 0,171 & 0,370 & 0,393 & 0,520 & 0,348 & 0,238 \\
\hline & 0,561 & 0,543 & 0,250 & 0,010 & & \\
\hline & 0,244 & 0,043 & 0,119 & & & \\
\hline & & 0,022 & & & & \\
\hline \multirow[t]{9}{*}{ DYS439 } & $n=30$ & $\mathrm{n}=41$ & $n=70$ & $\mathrm{n}=100$ & $\mathrm{n}=100$ & $n=46$ \\
\hline & & & 0,014 & & & \\
\hline & 0,067 & 0,024 & 0,100 & 0,010 & & \\
\hline & 0,200 & 0,366 & 0,243 & 0,040 & 0,022 & 0,020 \\
\hline & 0,033 & 0,146 & 0,157 & 0,460 & 0,196 & 0,257 \\
\hline & 0,700 & 0,464 & 0,400 & 0,400 & 0,630 & 0,564 \\
\hline & & & 0,057 & 0,090 & 0,130 & 0,129 \\
\hline & & & 0,029 & & 0,022 & 0,020 \\
\hline & & & & & & 0,010 \\
\hline
\end{tabular}


Dos nove STRs ligados ao cromossomo Y que podem ser individualizados, cinco (DYS19, DYS389I, DYS390, DYS393 e DYS439) apresentaram o mesmo alelo mais freqüente nas três amostras analisadas.

No locus DYS19, os três alelos mais freqüentes $(* 15, * 16$ e *17) entre os africanos não são os mais freqüentes entre as outras comunidades relatadas na Tabela 6 e Figura 5.

No locus DYS389I, são encontrados dois alelos $(* 11$ e *15) são encontrados nas duas comunidades (CL e RV), no entanto, foram relatados apenas na populações africana (Tabela 6 e Figura 5).

O alelo DYS390*21 é altamente prevalente no relato em africanos, em contraste com sua baixa freqüência nas outras populações aqui consideradas (Tabela 6 e Figura 6).

As comunidades CL e RV, em conjunto com a amostra urbana $\mathrm{HM}$ e as amostras parentais, exibem diferenças nas freqüências dos alelos mais freqüentes do loci DYS392 e DYS438 (Tabela 6 e Figura 6 e 7).

Alguns alelos foram encontrados apenas nas amostras do presente estudo como é o caso do DYS438*14 encontrados nas três amostras, CL, RV e HM. O DYS391*12 nas duas comunidades, CL e RV. Os alelos DYS438*15 e DYS390*27 encontrado somente em RV. E o DYS19*12 e DYS 439*8 encontrado somente na amostra urbana, HM (Figuras 5, 6 e 7).

De um modo geral a amostra africana apresentou os maiores valores de diversidade gênica (DYS19, DYS389I, DYS389II, DYS438 e DYS439). Entre as amostras do presente estudo foi a urbana HM (DYS19, DYS389II, DYS3923, DYS438 e DYS439). A CL apresentou valores altos nos loci DYS389I e DYS391 e RV no DYS390 e DYS 392 (Tabela 7). 

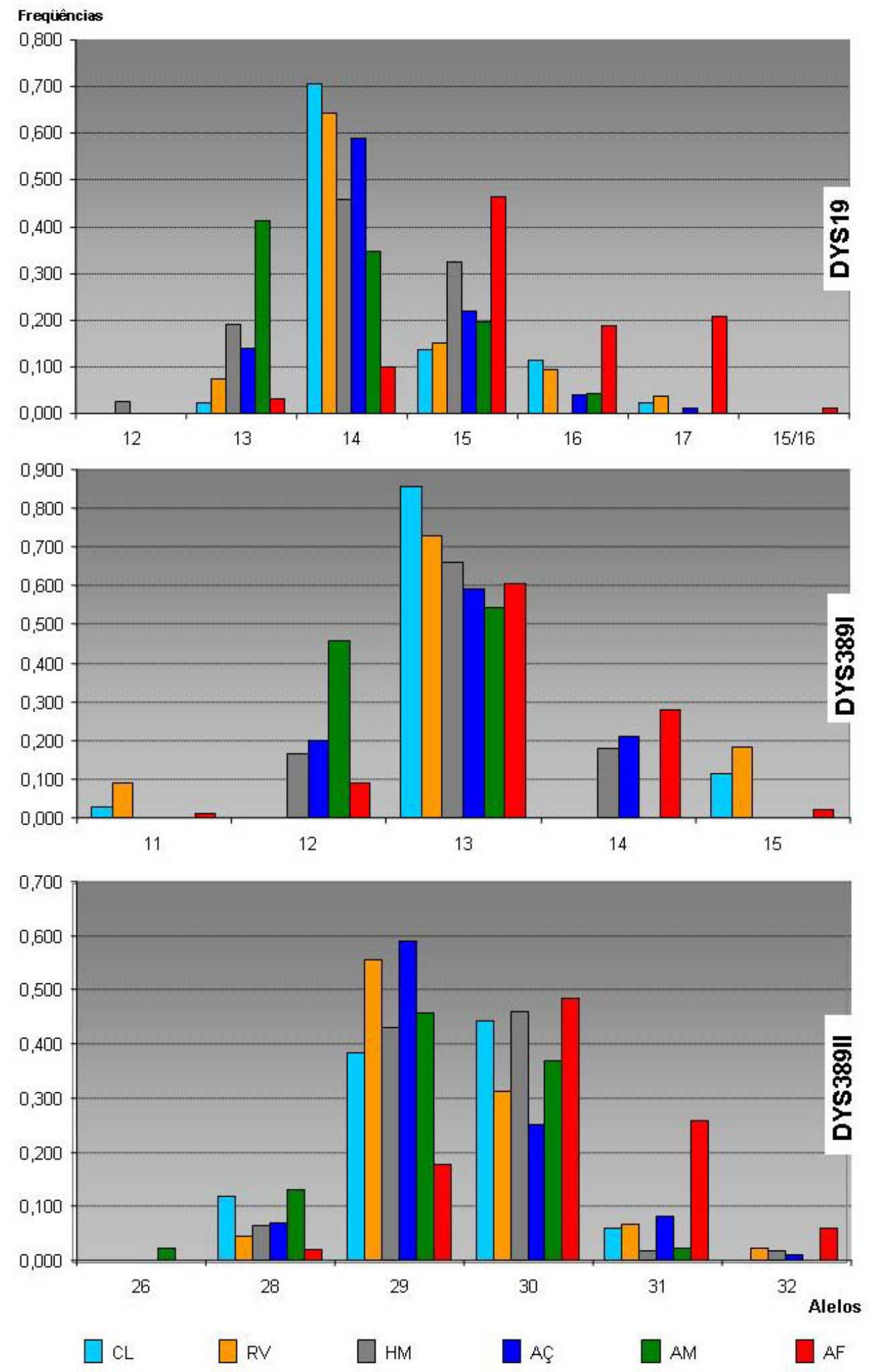

Figura 5: Comparação gráfica das freqüências alélicas de três STRs-Y (DYS19, DSYS389I e DYS389II) com as freqüências das populações parentais açorina, africana e ameríndia. 

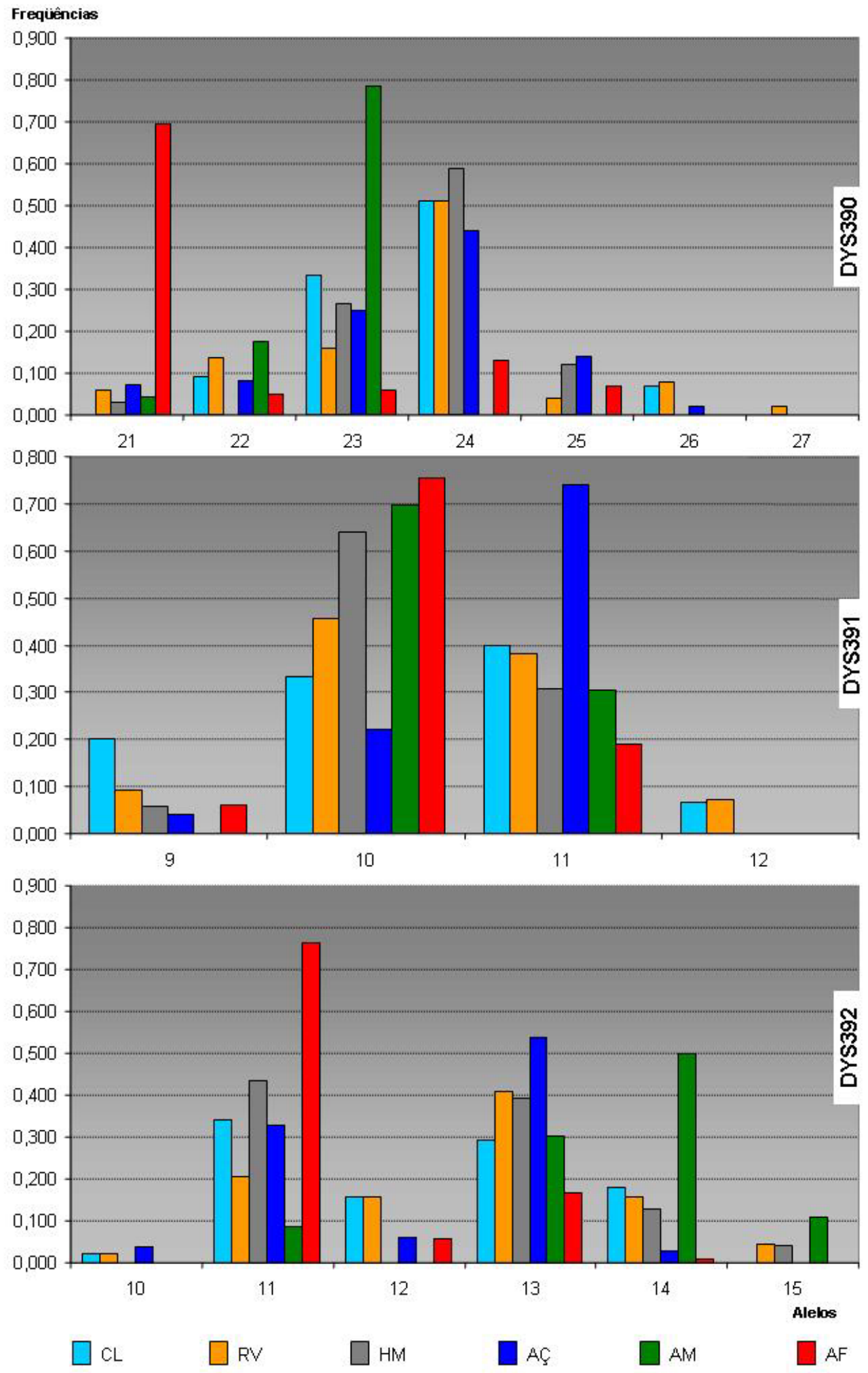

Figura 6: Comparação gráfica das freqüências alélicas de três STRs-Y (DYS390, DSYS391 e DYS392) com as freqüências das populações parentais açorina, africana e ameríndia. 

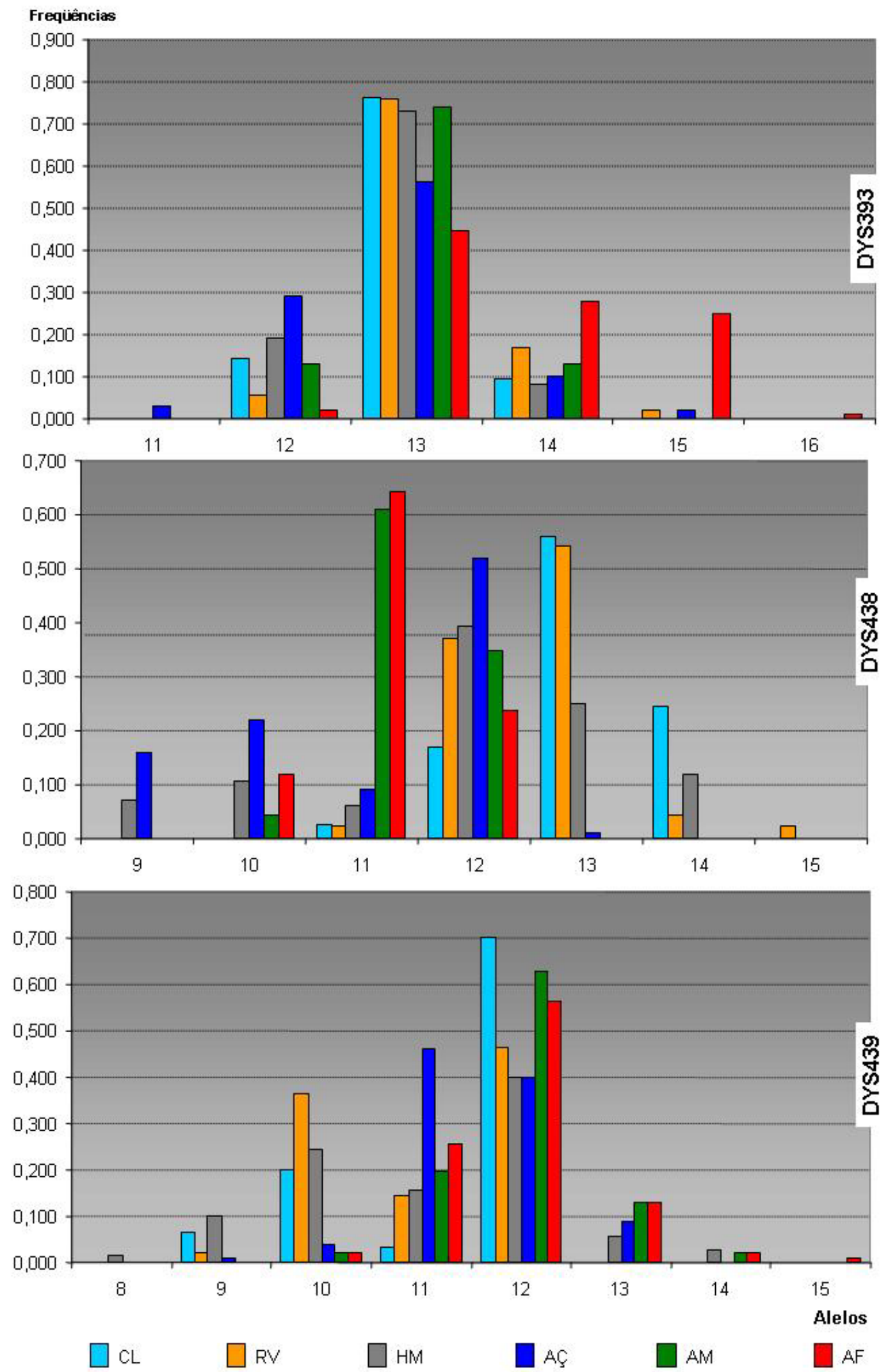

Figura 7: Comparação gráfica das freqüências alélicas de três STRs-Y (DYS393, SYS438 e DYS439I) com as freqüências das populações parentais açorina, africana e ameríndia. 
Tabela 7: Diversidade gênica $\left(H_{S}\right)$ de 10 STRs ligados ao cromossomo Y nas duas comunidades analisadas (CL e RV), na amostra urbana (HM) e nas parentais açoriana (FERNANDES \& BHREN, 2003). Africana (ROSA et al., 2006) e Ameríndia (LEITE et al., 2008). As $H_{S}$ dos loci DYS19, DYS390, DYS391, DYS392 e DYS 393 são de MUNIZ (2003).

\begin{tabular}{ccrrrrr}
\hline \hline Locus & CL & RV & HM & Açoriana & Ameríndia & Africana \\
\hline \hline DYS19 & 0,466 & 0,600 & 0,665 & 0,588 & 0,683 & 0,718 \\
\hline DYS389I & 0,661 & 0,601 & 0,606 & 0,573 & 0,507 & 0,598 \\
\hline DYS389II & 0,259 & 0,440 & 0,515 & 0,584 & 0,651 & 0,724 \\
\hline DYS390 & 0,650 & 0,720 & 0,586 & 0,719 & 0,363 & 0,497 \\
\hline DYS391 & 0,682 & 0,647 & 0,510 & 0,406 & 0,433 & 0,361 \\
\hline DYS392 & 0,775 & 0,771 & 0,668 & 0,599 & 0,652 & 0,225 \\
\hline DYS393 & 0,432 & 0,341 & 0,437 & 0,597 & 0,429 & 0,531 \\
\hline DYS438 & 0,611 & 0,578 & 0,758 & 0,654 & 0,518 & 0,520 \\
\hline DYS439 & 0,480 & 0,645 & 0,753 & 0,625 & 0,558 & 0,676 \\
\hline \hline
\end{tabular}

\section{DIVERSIDADE HAPLOTÍPICA E ANÁLISE DE VARIÂNCIA MOLECULAR (AMOVA)}

Considerando os loci DYS385a e DYS385b, o haplótipo mais comum é o 11/14, que também é o mais freqüente entre os açorianos. O haplótipo 12/16 foi encontrado exclusivamente em CL. Os haplótipos 14/19 (encontrado em HM), o 16/18 (em RV), o 15/18 (em HM e RV) e o 17/17 (na CL e HM) não foram encontrados em açorianos, mas foram descritos entre os africanos (Tabela 8 e Figura8).

Tabela 8: Distribuição das freqüências haplotípicas dos STRs DYS385a/b nas duas comunidades analisadas (CL e RV), na amostra urbana (HM) e nas populações parentais açoriana (FERNANDES \& BHREN., 2003), africana (ROSA et al., 2006) e ameríndia (LEITE et al., 2008).

\begin{tabular}{|c|c|c|c|c|c|c|}
\hline $\begin{array}{l}\text { Haplótipo } \\
\text { DYS385ab }\end{array}$ & $\begin{array}{c}\mathrm{CL} \\
\mathrm{n}=31\end{array}$ & $\begin{array}{c}\mathbf{R V} \\
\mathrm{n}=46\end{array}$ & $\begin{array}{c}\mathbf{H M} \\
\mathrm{n}=21\end{array}$ & $\begin{array}{c}\text { Açorianos } \\
n=100\end{array}$ & $\begin{array}{c}\text { Africanos } \\
n=203\end{array}$ & $\begin{array}{c}\text { Ameríndios } \\
n=46\end{array}$ \\
\hline 08/11 & & & & 0,010 & & \\
\hline $10 / 14$ & & & & 0,010 & & 0,010 \\
\hline $11 / 11$ & & & & 0,010 & 0,065 & \\
\hline $11 / 13$ & & 0,087 & 0,013 & 0,030 & 0,000 & 0,020 \\
\hline $11 / 14$ & 0,484 & 0,435 & 0,467 & 0,390 & 0,152 & 0,049 \\
\hline $11 / 15$ & 0,290 & 0,043 & 0,027 & 0,010 & & 0,010 \\
\hline $11 / 16$ & & & 0,027 & 0,010 & & \\
\hline $12 / 12$ & & & & 0,010 & & \\
\hline $12 / 13$ & & 0,022 & & 0,020 & & 0,010 \\
\hline $12 / 14$ & 0,032 & 0,043 & 0,027 & 0,080 & 0,065 & \\
\hline $12 / 15$ & 0,032 & & 0,013 & 0,020 & 0,022 & \\
\hline $12 / 16$ & 0,032 & & & & & \\
\hline $12 / 17$ & & & 0,013 & 0,010 & & \\
\hline $12 / 19$ & & & & 0,020 & & \\
\hline
\end{tabular}




\begin{tabular}{|c|c|c|c|c|c|c|}
\hline $\begin{array}{l}\text { Haplótipo } \\
\text { DYS385ab }\end{array}$ & $\begin{array}{c}\mathrm{CL} \\
\mathrm{n}=31\end{array}$ & $\begin{array}{c}\mathrm{RV} \\
\mathrm{n}=46\end{array}$ & $\begin{array}{l}\text { HM } \\
\mathrm{n}=21\end{array}$ & $\begin{array}{c}\text { Açorianos } \\
n=100\end{array}$ & $\begin{array}{c}\text { Africanos } \\
n=203\end{array}$ & $\begin{array}{c}\text { Ameríndios } \\
n=46\end{array}$ \\
\hline $13 / 13$ & 0,032 & & & 0,050 & 0,022 & \\
\hline $13 / 14$ & & 0,087 & 0,040 & 0,040 & & 0,040 \\
\hline $13 / 15$ & & 0,043 & 0,013 & 0,070 & 0,022 & \\
\hline $13 / 16$ & 0,032 & & 0,080 & 0,010 & 0,022 & 0,059 \\
\hline $13 / 17$ & & & 0,013 & 0,030 & 0,087 & \\
\hline $13 / 18$ & 0,032 & 0,022 & 0,013 & 0,040 & & \\
\hline $14 / 14$ & & 0,000 & 0,013 & 0,020 & 0,174 & \\
\hline $14 / 15$ & & 0,022 & 0,013 & 0,010 & 0,022 & \\
\hline $14 / 16$ & & & & & 0,130 & 0,030 \\
\hline $14 / 17$ & & 0,043 & 0,040 & 0,010 & 0,174 & 0,010 \\
\hline $14 / 18$ & & & 0,027 & & & 0,010 \\
\hline $14 / 19$ & & & 0,013 & & & 0,010 \\
\hline $15 / 15$ & & 0,065 & & 0,010 & & \\
\hline $15 / 16$ & & & 0,027 & 0,010 & & 0,020 \\
\hline $15 / 17$ & & & & & & 0,030 \\
\hline $15 / 18$ & & 0,022 & 0,027 & & & 0,039 \\
\hline $15 / 19$ & & & & & 0,022 & \\
\hline $15 / 20$ & & & & & & 0,010 \\
\hline $16 / 16$ & & 0,022 & 0,027 & 0,020 & & 0,109 \\
\hline $16 / 17$ & & 0,022 & 0,027 & 0,030 & 0,022 & 0,099 \\
\hline $16 / 18$ & & 0,022 & & & & 0,079 \\
\hline $16 / 19$ & & & & & & 0,020 \\
\hline $17 / 17$ & 0,032 & & 0,027 & & & 0,059 \\
\hline $17 / 18$ & & & & 0,020 & & 0,109 \\
\hline $17 / 19$ & & & & & & 0,148 \\
\hline $18 / 18$ & & & & & & 0,020 \\
\hline Diversidade & 0,758 & 0,789 & 0,796 & 0,836 & 0,903 & 0,751 \\
\hline
\end{tabular}

Foram encontrados 65 haplótipos diferentes, considerando o conjunto estendido de haplótipos. As três amostras aqui estudadas não exibiram haplótipos compartilhados (Tabela 9).

$\mathrm{Na}$ CL foram encontrados 14 diferentes haplótipos em 22 cromossomos. Cada um dos dois haplótipos mais comuns ocorreu duas vezes. Em RV foram encontrados 31 diferentes haplótipos em 32 indivíduos. Na amostra urbana HM foram amostrados 20 haplótipos não havendo nenhum repetido (Tabela 9). 


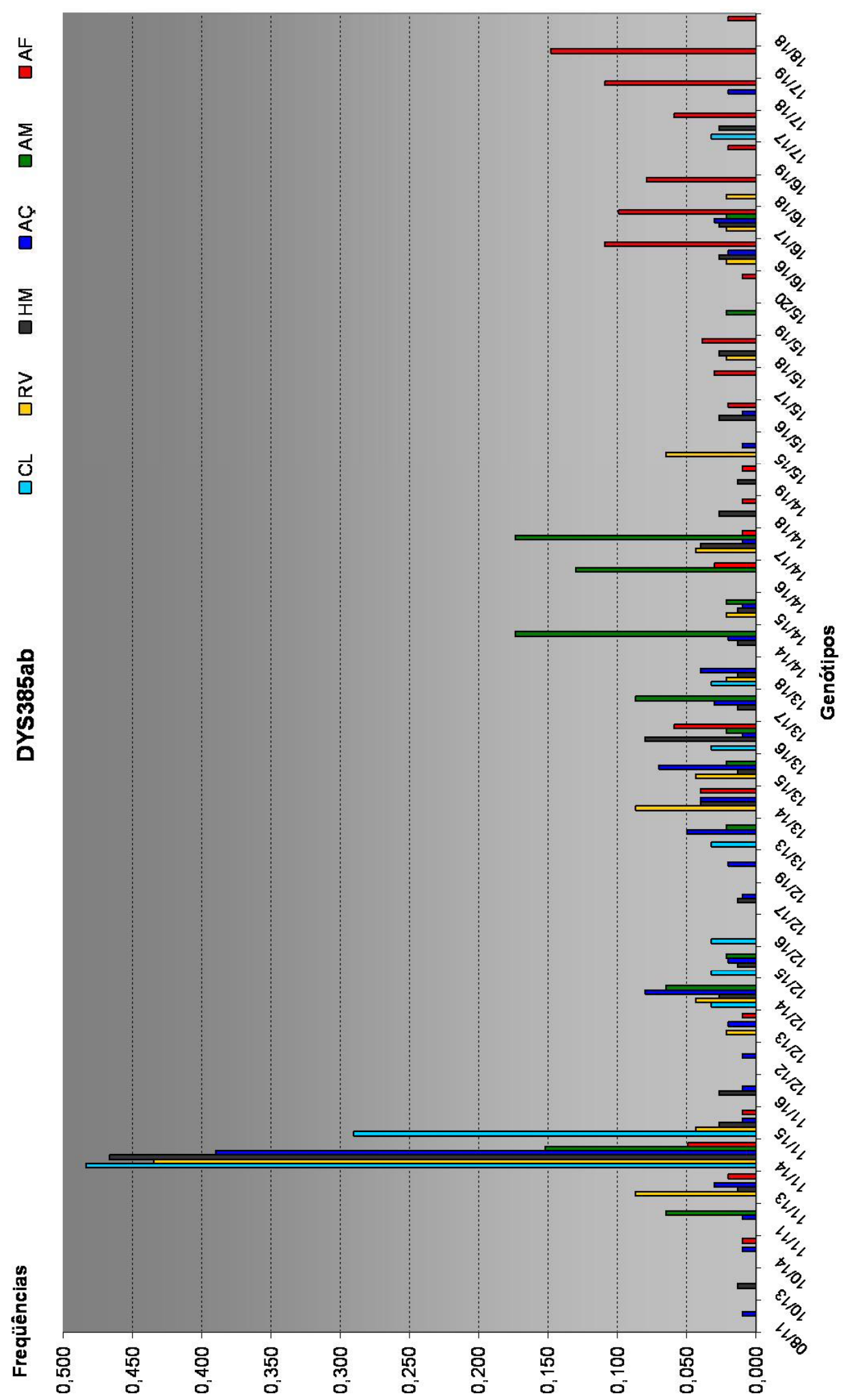

Figura 8: Comparação gráfica das freqüências haplotípicas do STR-Y DYS385ab com as freqüências das populações parentais açoriana (FERNANDES \& BREHN, 2003), africana (ROSA et al., 2006) e ameríndia (LEITE et al., 2008). 
Tabela 9: Descrição e Freqüência absoluta dos haplótipos estendidos nas duas populações (CL e $\mathrm{RV})$ e na amostra urbana (HM) estudadas.

\begin{tabular}{|c|c|c|c|c|c|c|c|c|c|c|c|c|c|}
\hline \multirow[b]{2}{*}{$\mathrm{N}^{\circ}$} & \multicolumn{10}{|c|}{ Número de repetições dos STRs } & \multicolumn{3}{|c|}{ Populações } \\
\hline & $\begin{array}{l}\text { DYS } \\
19\end{array}$ & $\begin{array}{l}\text { DYS } \\
\text { 385ab }\end{array}$ & $\begin{array}{l}\text { DYS } \\
3891\end{array}$ & $\begin{array}{l}\text { DYS } \\
389 \text { II }\end{array}$ & $\begin{array}{l}\text { DY } \\
\text { S390 }\end{array}$ & $\begin{array}{l}\text { DYS } \\
391\end{array}$ & $\begin{array}{l}\text { DYS } \\
392\end{array}$ & $\begin{array}{l}\text { DYS } \\
393\end{array}$ & $\begin{array}{l}\text { DYS } \\
438\end{array}$ & $\begin{array}{l}\text { DYS } \\
439\end{array}$ & CL & RV & HM \\
\hline$\overline{1 .}$ & $\overline{114}$ & $\begin{array}{l}11,14 \\
\end{array}$ & $\begin{array}{l}15 \\
\end{array}$ & 30 & $\overline{224}$ & 10 & $\bar{~} \overline{14}$ & $\overline{13}$ & $\overline{13}$ & $\overline{112}$ & 2 & & \\
\hline 2. & 15 & 11,14 & 13 & 31 & 26 & 10 & 12 & 13 & 12 & 11 & 1 & & \\
\hline 3. & 16 & 12,15 & 11 & 29 & 22 & 10 & 12 & 13 & 12 & 10 & 1 & & \\
\hline 4. & 14 & 11,15 & 13 & 30 & 24 & 11 & 15 & 14 & 12 & 12 & 1 & & \\
\hline 5. & 14 & 11,15 & 13 & 30 & 24 & 11 & 14 & 14 & 12 & 12 & 2 & & \\
\hline 6. & 14 & 11,14 & 13 & 29 & 24 & 11 & 12 & 13 & 13 & 12 & 1 & & \\
\hline 7. & 14 & 11,14 & 13 & 29 & 24 & 11 & 15 & 13 & 13 & 12 & 2 & & \\
\hline 8. & 14 & 11,15 & 13 & 30 & 23 & 11 & 15 & 13 & 14 & 12 & 2 & & \\
\hline 9. & 14 & 11,14 & 13 & 29 & 22 & 10 & 14 & 13 & 14 & 12 & 1 & & \\
\hline 10. & 14 & 11,15 & 13 & 30 & 22 & 11 & 14 & 13 & 14 & 12 & 1 & & \\
\hline 11. & 14 & 11,15 & 13 & 30 & 23 & 11 & 14 & 13 & 14 & 12 & 1 & & \\
\hline 12. & 14 & 11,14 & 13 & 30 & 26 & 10 & 13 & 13 & 14 & 12 & 1 & & \\
\hline 13. & 14 & 11,14 & 13 & 29 & 23 & 12 & 14 & 13 & 13 & 12 & 1 & & \\
\hline 14. & 14 & 13,13 & 13 & 31 & 23 & 10 & 12 & 12 & 12 & 10 & 1 & & \\
\hline 15. & 14 & 11,14 & 15 & 30 & 23 & 11 & 15 & 13 & 13 & 12 & & 1 & \\
\hline 16. & 13 & 11,14 & 13 & 29 & 24 & 12 & 16 & 13 & 13 & 12 & & 1 & \\
\hline 17. & 14 & 11,14 & 13 & 29 & 24 & 11 & 13 & 13 & 13 & 12 & & 1 & \\
\hline 18. & 14 & 11,13 & 13 & 29 & 24 & 09 & 13 & 13 & 13 & 11 & & 1 & \\
\hline 19. & 14 & 12,13 & 15 & 29 & 26 & 10 & 13 & 13 & 12 & 11 & & 1 & \\
\hline 20. & 13 & 13,14 & 15 & 30 & 24 & 09 & 12 & 13 & 11 & 10 & & 1 & \\
\hline 21. & 14 & 11,14 & 13 & 29 & 23 & 11 & 14 & 13 & 13 & 12 & & 1 & \\
\hline 22. & 14 & 11,14 & 13 & 29 & 23 & 11 & 14 & 13 & 14 & 12 & & 1 & \\
\hline 23. & 14 & 11,14 & 13 & 29 & 24 & 11 & 14 & 13 & 13 & 12 & & 1 & \\
\hline 24. & 14 & 13,15 & 13 & 29 & 22 & 10 & 11 & 13 & 12 & 10 & & 1 & \\
\hline 25. & 14 & 11,14 & 15 & 30 & 24 & 11 & 14 & 13 & 13 & 12 & & 1 & \\
\hline 26. & 14 & 11,15 & 15 & 31 & 24 & 10 & 14 & 13 & 13 & 12 & & 1 & \\
\hline 27. & 16 & 15,15 & 11 & 29 & 21 & 11 & 13 & 14 & 12 & 10 & & 2 & \\
\hline 28. & 14 & 11,13 & 13 & 29 & 24 & 10 & 15 & 13 & 13 & 11 & & 1 & \\
\hline 29. & 14 & 12,14 & 13 & 29 & 24 & 12 & 14 & 13 & 13 & 12 & & 1 & \\
\hline 30. & 14 & 15,18 & 13 & 30 & 24 & 10 & 12 & 13 & 14 & 10 & & 1 & \\
\hline 31. & 14 & 13,18 & 13 & 30 & 23 & 11 & 12 & 12 & 12 & 12 & & 1 & \\
\hline 32. & 15 & 11,14 & 13 & 30 & 27 & 10 & 15 & 13 & 13 & 12 & & 1 & \\
\hline 33. & 14 & 11,14 & 13 & 29 & 22 & 10 & 13 & 13 & 12 & 12 & & 1 & \\
\hline 34. & 13 & 16,18 & 13 & 32 & 24 & 09 & 11 & 13 & 15 & 10 & & 1 & \\
\hline 35. & 15 & 11,14 & 13 & 30 & 26 & 10 & 13 & 13 & 13 & 12 & & 1 & \\
\hline 36. & 13 & 13,14 & 15 & 30 & 25 & 09 & 12 & 13 & 12 & 10 & & 1 & \\
\hline 37. & 14 & 11,13 & 13 & 30 & 25 & 11 & 15 & 13 & 13 & 11 & & 1 & \\
\hline 38. & 16 & 14,15 & 13 & 30 & 21 & 11 & 12 & 14 & 12 & 10 & & 1 & \\
\hline 39. & 15 & 14,17 & 13 & 29 & 23 & 09 & 12 & 12 & 13 & 12 & & 1 & \\
\hline 40. & 15 & 16,17 & 13 & 29 & 23 & 10 & 14 & 15 & 12 & 10 & & 1 & \\
\hline 41. & 16 & 11,14 & 13 & 29 & 26 & 11 & 14 & 13 & 13 & 12 & & 1 & \\
\hline 42. & 17 & 15,15 & 11 & 29 & 24 & 11 & 12 & 14 & 12 & 10 & & 1 & \\
\hline 43. & 16 & 11,14 & 13 & 29 & 24 & 11 & 14 & 13 & 13 & 12 & & 1 & \\
\hline 44. & 15 & 11,14 & 15 & 31 & 24 & 10 & 14 & 13 & 13 & 10 & & 1 & \\
\hline 45. & 15 & 11,15 & 13 & 29 & 24 & 11 & 14 & 13 & 12 & 09 & & 1 & \\
\hline 46. & 15 & 11,15 & 12 & 29 & 23 & 11 & 13 & 13 & 12 & 11 & & & 1 \\
\hline 47. & 13 & 13,16 & 14 & 29 & 23 & 10 & 13 & 13 & 09 & 13 & & & 1 \\
\hline 48. & 15 & 15,18 & 14 & 32 & 21 & 10 & 11 & 13 & 11 & 12 & & & 1 \\
\hline 49. & 14 & 10,13 & 14 & 30 & 23 & 11 & 14 & 14 & 10 & 10 & & & 1 \\
\hline 50. & 14 & 11,14 & 13 & 29 & 24 & 10 & 11 & 13 & 12 & 11 & & & 1 \\
\hline 51. & 15 & 16,16 & 12 & 29 & 24 & 10 & 15 & 13 & 09 & 12 & & & 1 \\
\hline 52. & 13 & 12,17 & 12 & 29 & 24 & 10 & 11 & 12 & 10 & 12 & & & 1 \\
\hline 53. & 14 & 11,14 & 14 & 30 & 24 & 11 & 13 & 13 & 12 & 11 & & & 1 \\
\hline 54. & 13 & 15,16 & 12 & 30 & 24 & 10 & 11 & 13 & 10 & 13 & & & 1 \\
\hline 55. & 14 & 11,14 & 13 & 29 & 24 & 10 & 13 & 13 & 12 & 12 & & & 1 \\
\hline
\end{tabular}




\begin{tabular}{|c|c|c|c|c|c|c|c|c|c|c|c|c|c|}
\hline \multirow[b]{2}{*}{$\mathrm{N}^{\circ}$} & \multicolumn{10}{|c|}{ Número de repetições dos STRs } & \multicolumn{3}{|c|}{ Populações } \\
\hline & $\begin{array}{l}\text { DYS } \\
19\end{array}$ & $\begin{array}{l}\text { DYS } \\
\text { 385ab }\end{array}$ & $\begin{array}{l}\text { DYS } \\
3891\end{array}$ & $\begin{array}{l}\text { DYS } \\
38911\end{array}$ & $\begin{array}{l}\text { DY } \\
\text { S390 }\end{array}$ & $\begin{array}{l}\text { DYS } \\
391\end{array}$ & $\begin{array}{l}\text { DYS } \\
392\end{array}$ & $\begin{array}{l}\text { DYS } \\
393\end{array}$ & $\begin{array}{l}\text { DYS } \\
438\end{array}$ & $\begin{array}{l}\text { DYS } \\
439\end{array}$ & CL & RV & HM \\
\hline$\overline{c 56 .}$ & $\overline{14}$ & 111,14 & 13 & 29 & 23 & $\overline{111}$ & 13 & 13 & 12 & 12 & & & $\overline{11}$ \\
\hline 57. & 12 & 11,13 & 14 & 30 & 23 & 10 & 14 & 13 & 10 & 10 & & & 1 \\
\hline 58. & 14 & 12,15 & 13 & 29 & 23 & 10 & 14 & 13 & 13 & 12 & & & 1 \\
\hline 59. & 13 & 15,16 & 13 & 30 & 24 & 10 & 11 & 12 & 10 & 14 & & & 1 \\
\hline 60. & 13 & 16,17 & 13 & 30 & 23 & 10 & 11 & 13 & 13 & 12 & & & 1 \\
\hline 61. & 15 & 11,14 & 13 & 29 & 24 & 10 & 13 & 13 & 12 & 11 & & & 1 \\
\hline 62. & 14 & 13,16 & 13 & 29 & 23 & 10 & 11 & 12 & 09 & 12 & & & 1 \\
\hline 63. & 15 & 14,15 & 13 & 30 & 24 & 11 & 11 & 13 & 10 & 13 & & & 1 \\
\hline 64. & 14 & 11,14 & 13 & 28 & 24 & 11 & 13 & 13 & 12 & 12 & & & 1 \\
\hline 65. & 15 & 12,14 & 13 & 30 & 25 & 11 & 11 & 13 & 12 & 10 & & & 1 \\
\hline \multicolumn{11}{|c|}{$\mathrm{N}^{\circ}$ cromossomos (n) } & 22 & 32 & 20 \\
\hline \multicolumn{11}{|c|}{ Número de haplótipos $(k)$} & 14 & 31 & 20 \\
\hline \multirow{2}{*}{\multicolumn{11}{|c|}{ Diversidade haplotípica $(h)$}} & 0.974 & 0,998 & 1 \\
\hline & & & & & & & & & & & 0.025 & 0,009 & 0,016 \\
\hline
\end{tabular}

Comparando os haplótipos das amostras do presente estudo com amostras parentais e outras utilizadas foi possível verificar que o haplótipo 16 (14/11,14/13/29/24/11/14/13/13/12), verificado na amostra de RV, aparece uma vez em amostra de Portugal (PONTES et al., 2007).

Considerando três haplótipos $50, \quad 53$ e 56 (14/11,14/13/29/24/10/13/13/12/12, 14/11,14/14/30/24/11/13/13/12/11 e 14/11,14/13/29/23/11/13/13/12/12) descritos na amostra HM, o primeiro deles foi relatado uma vez em Portugal (PONTES et al., 2007) e São Paulo (GÓIS et al., 2008) e duas vezes na Espanha (MARTÍN et al., 2004); o segundo, uma vez em Açores (FERNADES \& BREHM 2003) e São Paulo, quatro vezes em Portugal e cinco vezes na Espanha e o último, uma vez em Portugal, três em Açores e na Espanha.

A análise com apenas oito STRs (haplótipo mínimo) possibilita comparar os resultados presentes com um maior número de populações mundiais, uma vez que é mais difícil encontrar amostras nas quais tenha sido estudado o haplótipo estendido.

Foram aqui comparados apenas os haplótipos compartilhados entre as amostras do presente estudo e as disponíveis na literatura. As populações consideradas como parentais neste trabalho foram descritas, com as respectivas referências bibliográficas, na seção 
Material \& Métodos (57-58pp). Na comunidade da CL quatro haplótipos estão presentes duas vezes $\quad(14 / 11,14 / 15 / 30 / 24 / 10 / 14 / 13 ; \quad 14 / 11,15 / 13 / 30 / 24 / 11 / 14 / 14 ; \quad 14 / 11,14 / 13 / 29 / 24 / 11 / 15 / 13$; 14/11,15/13/30/23/11/15/13). Em RV dois haplótipos foram encontrados duas vezes cada (14/11,14/13/29/23/11/14/14; 16/15,15/11/29/21/11/13/14). Na amostra urbana HM, um haplótipo (14/11,14/14/30/24/11/13/13) aparece três vezes, um outro (14/11,14/13/29/23/11/13/13), cinco vezes e outros dois (14/11,14/13/29/24/10/13/13; 15/11,14/13/29/24/10/13/13), duas vezes cada.

O haplótipo 14/11,14/13/29/24/11/12/13 foi encontrado apenas na comunidade CL e na amostra de São Paulo.

A comunidade de RV apresenta um haplótipo (14/11,14/13/29/24/11/13/13) que aparece em várias outras amostras relatadas na literatura: Guiné-Equatorial, regiões Norte, Sudeste e Sul brasileiros, Açores, Espanha, Portugal.

O haplótipo 14/11,14/13/29/24/11/14/13, encontrado na mesma comunidade de RV, é compartilhado com amostras do Rio Grande do Sul e de Portugal. Ainda da mesma comunidade, os haplótipos 14/13,15/13/29/22/10/11/13; 14/11,13/13/29/24/10/15/13 e 14/11,14/13/29/22/10/13/13 aparecem, respectivamente, no Rio Grande do Sul, em Santa Catarina e no Centro-oeste brasileiro.

O haplótipo 14/11,14/13/29/23/11/13/13 é encontrado na amostra HM e também na Espanha, Portugal, Guiné-Equatorial, e nas regiões Centro-oeste e Sul do Brasil.

Observados na mesma comunidade HM, os haplótipos 14/11,14/14/30/24/11/13/13 e 14/11,14/13/29/24/10/13/13 são também encontrados em Portugal, Espanha, São Paulo, Rio Grande do Sul e nas regiões Nordeste e Norte do Brasil. O haplótipo 15/11,14/13/29/24/10/13/13 duas vezes em São Paulo e Portugal e uma vez na Espanha. O haplótipo 14/13,16/13/29/23/10/11/12 uma vez em Portugal e no Nordeste brasileiro. E os haplótipos 
13/13,16/14/29/23/10/13/13; 12/11,13/14/30/23/10/14/13 e 13/16,17/13/30/23/10/11/13 uma vez no Rio

Grande do Sul, Santa Catarina e região Sudeste do Brasil, respectivamente.

A diversidade haplotípica $(h)$ estimada com base nos 11 STRs que compõem o haplótipo estendido teve seu valor mais alto na amostra HM $(1,000)$ e mais baixo na CL $(0,974)$. Dentre as parentais o menor valor foi na população ameríndia $(0,529)$ e o mais alto foi entre os açorianos $(0,998)$ (Tabela 10$)$.

Tabela 10: Diversidade haplotípica $(h)$ do haplótipo estendido do cromossomo $Y$ nas duas comunidades analisadas (CL e RV) e na amostra urbana (HM) e nas parentais açoriana (FERNANDES \& BHREN, 2003). Africana (ARROYO-PARDO et al., 2005) e Ameríndia (LEITE et al., 2008)

\begin{tabular}{cc}
\hline \hline Populações & $\boldsymbol{h}$ \\
\hline \hline CL & 0,974 \\
RV & 0,998 \\
HM & 1,000 \\
Açoriana & 0,998 \\
Ameríndia & 0,529 \\
Africana & 0,903 \\
\hline \hline
\end{tabular}

A hipótese de igualdade entre as duas comunidades pode ser rejeitada uma vez que o teste exato de diferenciação entre elas (comparação dos haplótipos par a par) resultou significativo ( $\mathrm{p}<<0,001)$. Por outro lado, a análise de variância molecular (AMOVA), também com os 11 STRs do haplótipo estendido do cromossomo Y, mostrou que a maior parte da diversidade haplotípica foi observada dentro das populações $(94,24 \%)$ e que somente $5,76 \%$ das diferenças haplotípicas ocorreram entre as comunidades.

\section{AIMS. FREQÜÊNCIAS ALÉLICAS E DIVERSIDADE GENÉTICA}

Ambos os alelos de cada um dos oito AIMs (FY, RB, LPL, AT3, Sb19.3, APO, PV92 e CYP1A1) foram encontrados nas amostras aqui estudadas (Tabela 11 e Figura 9). 
Tabela 11: Freqüências alélicas dos oito AIMs e diversidade genética $\left(H_{S}\right)$ nas duas comunidades $(\mathrm{CL}$ e RV) e na população urbana (HM). As freqüências se referem ao alelo $C Y P 1 A 1 * 2 C$ e aos alelos $* 1$ dos demais loci.

\begin{tabular}{|c|c|c|c|c|c|c|c|c|c|}
\hline & \multicolumn{3}{|c|}{$\mathrm{CL}$} & \multicolumn{3}{|c|}{ RV } & \multicolumn{3}{|c|}{ HM } \\
\hline & $n$ & Freq & $H_{S}$ & $n$ & Freq & $H_{S}$ & $\mathrm{n}$ & Freq & $H_{S}$ \\
\hline$\overline{F Y}$ & 54 & $\overline{0,926}$ & 0,138 & 699 & 0,862 & $\overline{0,239}$ & 15 & 0,900 & $\overline{0,186}$ \\
\hline RB & 101 & 0,287 & 0,411 & 127 & 0,374 & 0,47 & 34 & 0,397 & 0,487 \\
\hline LPL & 96 & 0,661 & 0,450 & 66 & 0,561 & 0,497 & 34 & 0,574 & 0,498 \\
\hline AT3 & 100 & 0,530 & 0,501 & 117 & 0,372 & 0,469 & 35 & 0,143 & 0,251 \\
\hline Sb19.3 & 100 & 0,940 & 0,113 & 127 & 0,839 & 0,272 & 33 & 0,803 & 0,321 \\
\hline APO & 99 & 0,894 & 0,191 & 127 & 0,835 & 0,277 & 33 & 0,939 & 0,116 \\
\hline PV92 & 101 & 0,351 & 0,458 & 124 & 0,262 & 0,388 & 36 & 0,236 & 0,367 \\
\hline CYP1A1 & 101 & 0,020 & 0,039 & 126 & 0,06 & 0,112 & 36 & 0,069 & 0,131 \\
\hline $\begin{array}{l}H_{S} \pm \text { Desvio } \\
\text { Padrão }\end{array}$ & & & 65 & & & 18 & & & ,053 \\
\hline
\end{tabular}

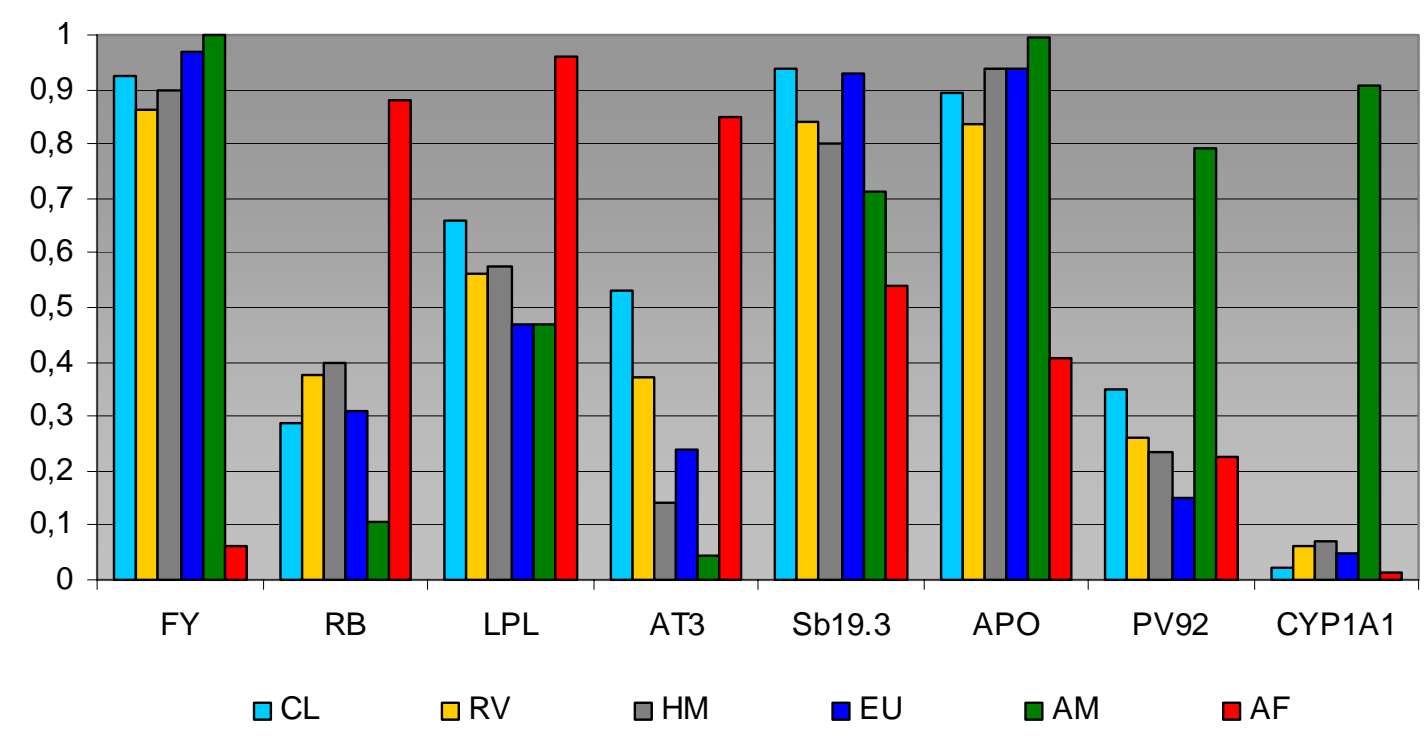

Figura 9: Comparação das freqüências dos AIMs (alelo *1) entre as comunidades de CL, RV e a população urbana (HM) com as populações parentais EUropéia (Portugueses; TOMÁS et al., 2002), AFricana (PARRA et al., 1998) e AMeríndia (LUIZON et al., 2008a) (Materiais e Métodos, pág 56-58pp).

Muitas populações não tiveram descritas ainda as freqüências dos marcadores PV92 e CYP1A1, razão pela qual não foram considerados como base da estimativa da diversidade genética $\left(H_{S}\right)$ em diferentes populações mundiais (Tabela 12). 
Tabela 12: Diversidade genética $\left(H_{S}\right)$ obtida a partir dos AIMs FY, RB, LPL, AT3, Sb19.3 e APO entre diferentes populações mundiais.

\begin{tabular}{lllc}
\hline \hline \multicolumn{1}{c}{ Populações } & \multicolumn{1}{c}{$\mathbf{n}$} & $\begin{array}{c}\text { Hs } \pm \text { desvio } \\
\text { padrão }\end{array}$ & Refs. \\
\hline \hline Europa & 407 & $0,295 \pm 0,090$ & $(1)$ \\
Inglaterra & 44 & $0,291 \pm 0,101$ & $(2)$ \\
Irlanda & 86 & $0,282 \pm 0,095$ & $(2)$ \\
Alemanha & 30 & $0,340 \pm 0,095$ & $(2)$ \\
Portugal & 168 & $0,297 \pm 0,086$ & $(3)$ \\
Espanha & 79 & $0,299 \pm 0,093$ & $(4)$ \\
África & 474 & $0,186 \pm 0,085$ & $(1)$ \\
República Centro Africana & 49 & $0,189 \pm 0,083$ & $(3)$ \\
Nigéria-1 & 46 & $0,189 \pm 0,086$ & $(3)$ \\
Nigéria-2 & 100 & $0,171 \pm 0,090$ & $(3)$ \\
Serra Leoa (Mende) & 181 & $0,192 \pm 0,083$ & $(5)$ \\
Serra Leoa (Temne) & 98 & $0,189 \pm 0,090$ & $(5)$ \\
Indígenas da América do Norte & 184 & $0,285 \pm 0,090$ & $(1)$ \\
$\quad$ Maias & 96 & $0,293 \pm 0,088$ & $(4)$ \\
Pima, Pueblo e Cheyenne & 88 & $0,277 \pm 0,095$ & $(4)$ \\
Afro-Americanos & 1020 & $0,327 \pm 0,051$ & $(1)$ \\
Euro-Americanos & 125 & $0,302 \pm 0,092$ & $(1)$ \\
\hline \hline
\end{tabular}

Referências: (1) Valores obtidos a partir de médias ponderadas das freqüências alélicas apresentadas em Materiais e Métodos e em PARRA et al. 1998. (2) PARRA et al. 1998, (3) TOMAS et al. 2002, (4) dbSNP/NCBI (http://www.ncbi.nlm.nih.gov/SNP/), (5) PARRA et al, 2001.

A heterozigose $\left(H_{S}\right)$ observada entre as comunidades do presente estudo (Tabela 11) apresentou valores concordantes com os observados em Europeus e Euro-americanos dos EUA (PARRA et al., 2001).

\section{EQUILÍBRIO DE HARDY-WEINBERG}

As freqüências genotípicas dos oito AIMs foram comparadas aos valores esperados pelo equilíbrio de Hardy-Weinberg pelo teste exato e foram observados quatro desvios significativos (Tabela 13), todos eles causados por deficiência de heterozigotos, confirmados pelo teste sensível à deficiência de heterozigotos.

Dado o número de testes independentes (24), a significância foi recalculada com a correção de Bonferroni (HARTL \& CLARK 2007). Por este procedimento, o limite $\alpha$ de 5\% foi recalculado pelo número de testes $(0,050 / 24)$, derivando-se daí o valor corrigido de 
$\alpha_{\text {Bonf }}=0,002$. Três dos quatro valores inicialmente significativos mantiveram-se nesta condição.

Tabela 13: Probabilidade de desvio casual segundo teste exato (GUO \& THOMPSON 1992) na verificação do equilíbrio de Hardy-Weinberg. * Os valores significativos antes e ** após a correção Bonferroni $\left(\alpha_{\text {Bonf }}<0,002\right)$.

\begin{tabular}{lrrrrrrrrr}
\hline \hline & FY & RB & LPL & AT3 & Sb19.3 & APO & PV92 & CYP1A1 & Multi-locus \\
\hline \hline CL & 1 & 1 & 0,494 & 0,693 & 0,296 & ${ }^{*}<10^{-4}$ & 0,383 & 1 & ${ }^{\star *}<10^{-4}$ \\
RV & 0,602 & 0,705 & 1 & 1 & ${ }^{*} 0,005$ & ${ }^{* *} 0,001$ & 0,818 & 0,358 & ${ }^{*} 0,029$ \\
HM & 1 & 0,722 & 0,289 & ${ }^{*} 0,000$ & 1 & 1 & 0,364 & 1 & 0,151 \\
\hline $\begin{array}{l}\text { Multi- } \\
\text { populacional }\end{array}$ & 0,977 & 0,874 & 0,867 & ${ }^{*} 0,027$ & 0,105 & ${ }^{*}<10^{-4}$ & 0,825 & 0,914 & ${ }^{*}<10^{-4}$ \\
\hline \hline
\end{tabular}

$\mathrm{Na}$ análise multi-locus as populações CL e RV encontraram-se em desequilíbrio. E na análise multi-populacional o loci AT3 e APO encontram-se em desequilíbrio.

\section{DESEQUILÍBRIO DE LIGAÇÃO}

Associações significativas entre loci não ligados são indicativas de ALD (Admixture Linkage Disequilibrium), isto é, desequilíbrio de ligação gerado pela mistura recente (PFAFF et al. 2001). As mesmas sugerem a presença de estrutura genética, razão pela qual o padrão de associações par a par entre os AIMs não ligados foi analisado. Os locus FY e AT3, distantes 22cM e considerados ligados (PARRA et al. 1998), também foram incluídos na análise.

Em cada uma das populações, os oito AIMs considerados par a par permitiram 28 comparações. Dentre as comunidades fundadas por açorianos foram observadas associações entre os loci RB/AT3 $p=0,014), \mathrm{RB} / \mathrm{Sb} 19.3 p=0,015)$, AT3/Sb19.3 $p=0,047), \mathrm{RB} / \mathrm{APO}$ $p=0,020)$ e APO/PV92 $p=0,021)$ em CL, e entre os loci AT3/Sb19.3 $p=0,003$ ) em RV. Na amostra urbana do HM foi observada associação entre os loci LPL/Sb19.3 p=0,030).

Pelo nível de significância aqui considerado $(\alpha=0,05)$ seriam esperadas de uma a duas associações significativas. No entanto, após realizada a correção de Bonferroni, com o novo 
valor de significância admitido, isto é, $\alpha_{\text {bonf }}=0,0018$ (correspondente a 0,05/28 comparações), nenhuma associação foi considerada significativa.

\section{DIFERENCIAÇÃO POPULACIONAL}

A diferenciação genética entre as comunidades (Tabela 14) foi estimada a partir das freqüências do locus componentes do haplótipo estendido. Somente a freqüência alélica do DYS438 apresentou diferença significativa $(p=0,015)$ entre as duas comunidades (CL e RV). Seis loci diferenciaram a comunidade da CL da amostra urbana $(p<<0,001$ a $p=0,010)$ e quatro diferenciaram RV da amostra urbana $(p<<0,001$ a $\mathrm{p}=0,028)$. Considerando todos os loci em conjunto, as duas comunidades não se diferenciam entre si, mas ambas se diferenciam da amostra urbana.

Tabela 14: Diferenciação gênica baseada nos loci do haplótipo estendido do cromossomo Y entre as duas comunidades (CL e RV) e a amostra urbana (HM) aqui estudadas. *Valores significativos $(p<0,05)$.

\begin{tabular}{|c|c|c|c|}
\hline Loci & $\begin{array}{c}\text { Diferenciação gênica } \\
\text { CL X RV }\end{array}$ & CL X HM & RV X HM \\
\hline DYS385a/b & 0,762 & 0,115 & 0,363 \\
\hline DYS438 & ${ }^{*} 0,013$ & $*^{*} 0,000$ & ${ }^{*} 0,002$ \\
\hline DYS439 & 0,088 & 0,145 & 0,307 \\
\hline DYS389II & 0,353 & 0,727 & 0,360 \\
\hline DYS389I & 0,406 & ${ }^{*} 0,000$ & ${ }^{*} 0,000$ \\
\hline DYS19 & 0,536 & $\star^{*} 0,001$ & $* 0,028$ \\
\hline DYS390 & 0,199 & $\star^{*} 0,010$ & 0,014 \\
\hline DYS391 & 0,469 & ${ }^{*} 0,004$ & 0,163 \\
\hline DYS392 & 0,622 & $*^{*} 0,000$ & $* 0,000$ \\
\hline DYS393 & 0,260 & 1,000 & 0,137 \\
\hline Total & 0,067 & ${ }^{*} 0,000$ & ${ }^{\star} 0,000$ \\
\hline
\end{tabular}

$\mathrm{Na}$ análise da diferenciação populacional, as comunidades de CL e RV se diferenciam de todas as populações a que foram comparadas (as parentais: Açores, Guiné-Bissau, ameríndios; e outras: Portugal, Espanha, Rio Grande do Sul e São Paulo; Material e Métodos 
(58p), enquanto que HM não apresenta diferença com as amostras Rio Grande do Sul, São Paulo, Espanha e Portugueses.

A comparação das freqüências alélicas e genotípicas dos AIMs entre as duas comunidades (CL e RV) e a amostra urbana (HM) par a par, pelo teste exato de Fisher, revela diferenças altamente significativas $(\mathrm{p}<0,001)$ quando considerados todos os loci, exceto entre RV e HM considerando as freqüências genotípicas.

\section{DIVERSIDADE INTERPOPULACIONAL (ESTATÍSTICAS F)}

\section{- Coeficiente de endogamia $\left(F_{I S}, A I M s\right)$}

O coeficiente de endogamia $\left(F_{I S}\right)$ só não foi significativo em CL (Tabela 15).

Tabela 15: Valores de $F_{I S}$ nas populações analisadas. *Valores com intervalo de confiança (95\%) significativos.

\begin{tabular}{lcc}
\hline \hline & Populações & $\boldsymbol{F}_{I S}$ \\
\hline \hline $\mathrm{CL}$ & 0,041 \\
$\mathrm{RV}$ & $\mathbf{0 , 0 8 7}$ \\
$\mathrm{HM}$ & $\mathbf{0 , 1 5 9}$ \\
Africanos & $-0,036$ \\
Europeus & $-0,035$ \\
Ameríndios & $\mathbf{0 , 1 4 2}$ \\
\hline \hline
\end{tabular}

\section{- Diversidade inter-populacional $\left(F_{S T}\right)$}

Os valores de $F_{S T}$ obtidos a partir dos AIMs não foram significativos somente entre RV x HM e Europeus x HM (Tabela 16). 
Tabela 16: Valores de $F_{S T}$ nos diferentes pares de populações obtidos a partir dos 7 AIMs (exceto o CYP1A1). *Valores com intervalo de confiança (95\%) significativos.

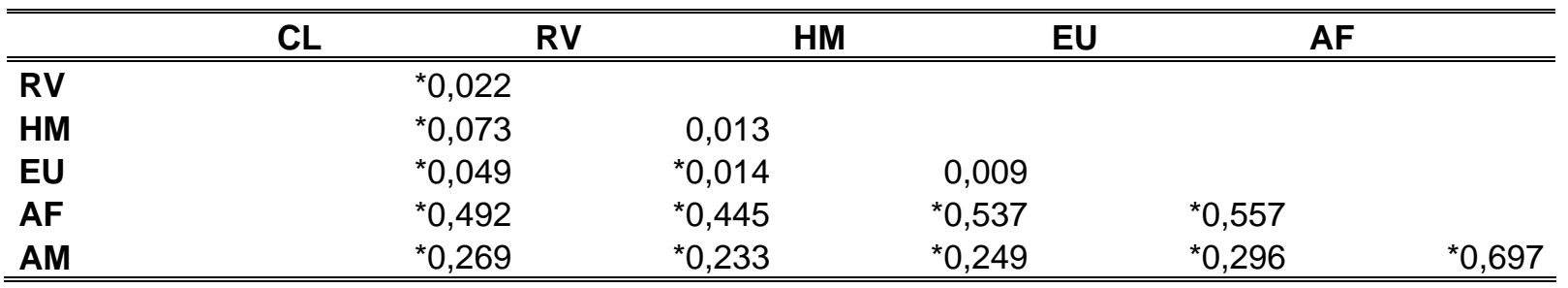

Todos os valores de $F_{S T}$ obtidos a partir do haplótipo estendido foram significativos (Tabela 17).

Tabela 17: Valores de $F_{S T}$ nos diferentes pares de populações obtidos a partir dos STRs do haplótipo estendido do cromossomo Y. Todos os valores são significativos, intervalo de confiança $95 \%$.

\begin{tabular}{lrrrrrr}
\hline \hline & CL & RV & HM & AÇ & AF \\
\hline RV & 0,014 & & & & \\
HM & 0,072 & 0,043 & & & \\
AÇ & 0,122 & 0,077 & 0,031 & & \\
AF & 0,326 & 0,265 & 0,184 & 0,245 & \\
AM & 0,175 & 0,117 & 0,066 & 0,123 & 0,227 \\
\hline \hline
\end{tabular}

\section{AIMS. ESTRUTURA POPULACIONAL}

Nas análises com o software STRUCTURE foram utilizados os genótipos de 55 indivíduos da Nigéria como parentais Africanos, 55 Espanhóis e Alemães como parentais Europeus (SHRIVER, comunicação pessoal), e 55 indivíduos aleatoriamente selecionados de quatro tribos indígenas da Amazônia Brasileira como parentais ameríndios (LUIZON et al., 2008a). A opção FLAG foi habilitada no intuito de determinar de forma mais precisa os clusters que representam os indivíduos reconhecidamente pertencentes a populações consideradas parentais. 
As análises foram realizadas com $K=3$ como parâmetro predefinido como o número de populações, com 30.000 interações no período burn-in e 100.000 interações adicionais na obtenção das estimativas dos parâmetros.

A Figura 10A mostra os agrupamentos (clusters) aos quais os indivíduos das seis populações, representados por barras, foram atribuídos de acordo com seus genótipos. A Figura 10B mostra os valores de atribuição das populações a cada um dos clusters. A grande parcela de atribuição dos africanos ao cluster 1 contrasta com mal distinção entre os clusters 2 e 3, responsáveis pela maioria dos ameríndios e europeus, respectivamente.

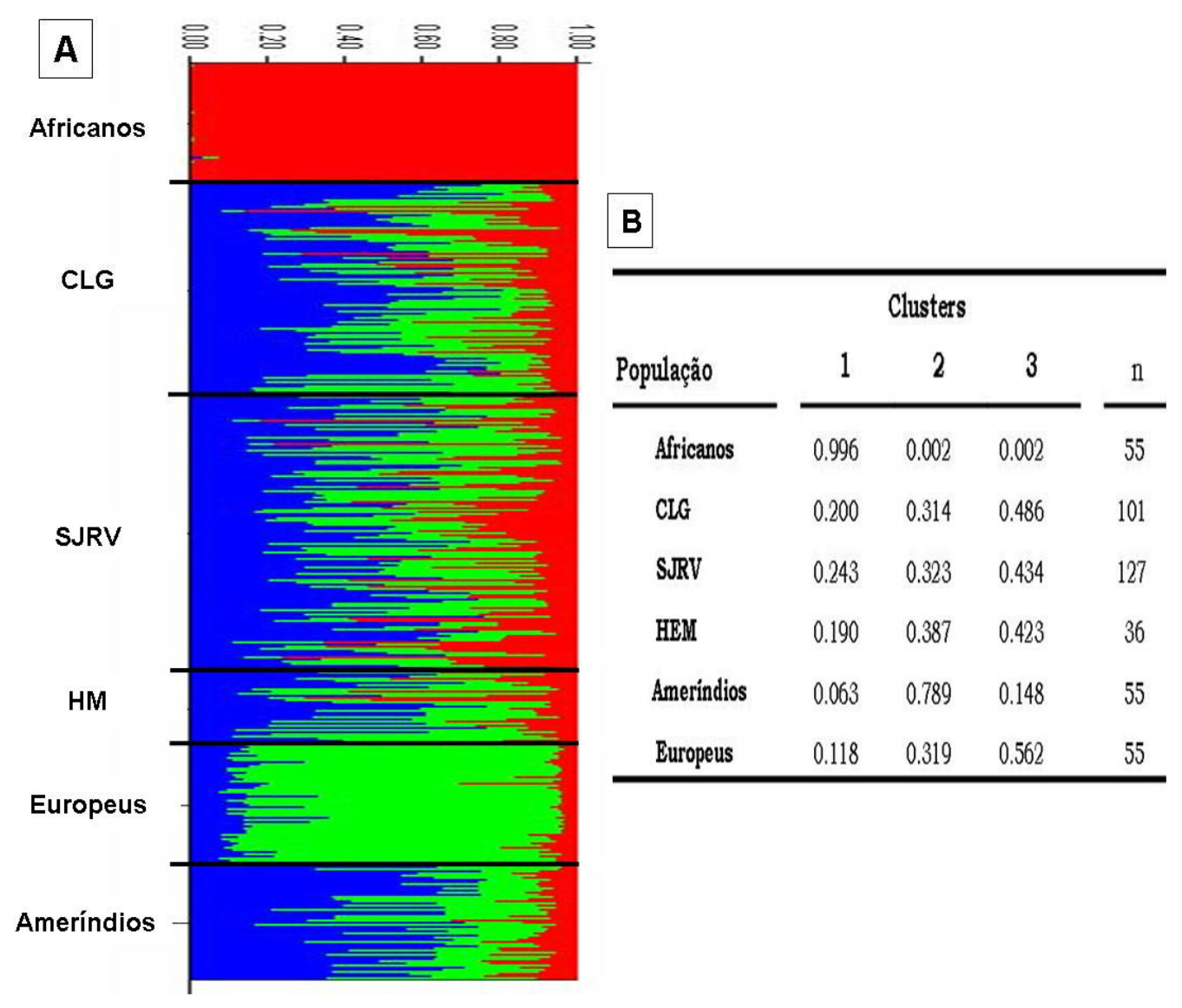

Figura 10: (A) Estrutura populacional nas comunidades e na população urbana em comparação com populações parentais; Africana, Ameríndia e Européia, obtido a partir de sete AIMs. Foram admitidas $\mathrm{k}=3$ populações, 30.000 interações no período burn-in e 100.000 interações nas estimativas dos parâmetros. (B) Proporção de associação de cada população a cada um dos três clusters. 
Todas as amostras populacionais analisadas apresentam estrutura populacional, isto é, sub-populações de indivíduos geneticamente similares (Figura 10A), embora com graus diferentes. O diagrama triangular reforça esta interpretação, em que os indivíduos de cada população estão representados por círculos (Figura 11).

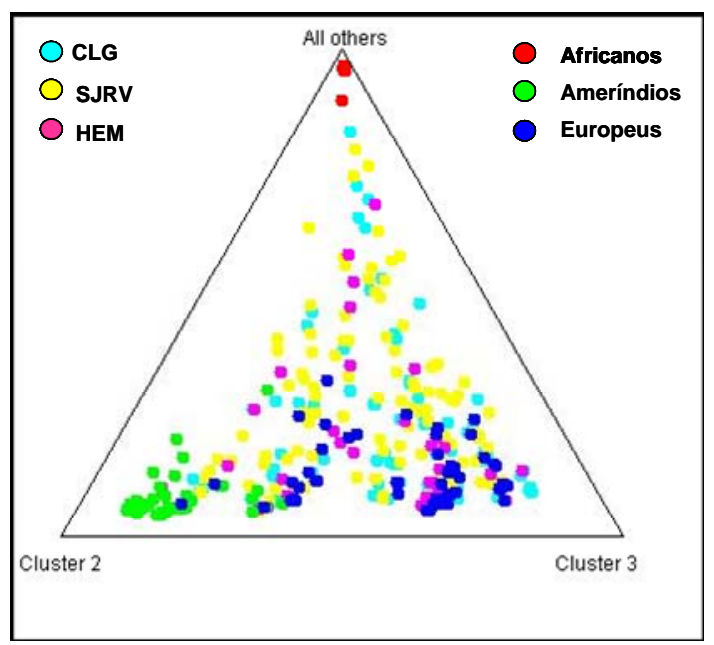

Figura 11: Agrupamento dos indivíduos (círculos) das comunidades de CL, RV e da amostra do HM, de acordo a contribuição dos grupos étnicos parentais: Africano, Ameríndio e Europeu.

É importante notar que estas análises não foram realizadas com o locus CYP1A1, pois o mesmo não apresenta dados disponíveis nas mesmas populações reconhecidas como parentais utilizadas nesta análise. Assim como lembrar também que o alelo $C Y P 1 A 1 * 2 C$ apresenta grandes diferencias de freqüência alélica entre populações ameríndias e africanas ou européias (LUIZON et al. 2008a).

\section{ANÁLISES DE COMPONENTE PRINCIPAL}

O objetivo das análises de componente principal foi verificar o agrupamento, com base nas freqüências alélicas, das comunidades fundadas por açorianos (CL e RV) e da amostra urbana do HM com populações africanas, européias, ameríndias, afro-americanas e euro-americanas. Para tanto, foram utilizadas as freqüências alélicas da literatura citadas no 
Material e Métodos (página@). As análises obtidas a partir de seis AIMs (FY, RB, LPL, AT3, Sb19.3 e APO) encontram-se na Figura 12 e nas Tabelas 18 e 19.

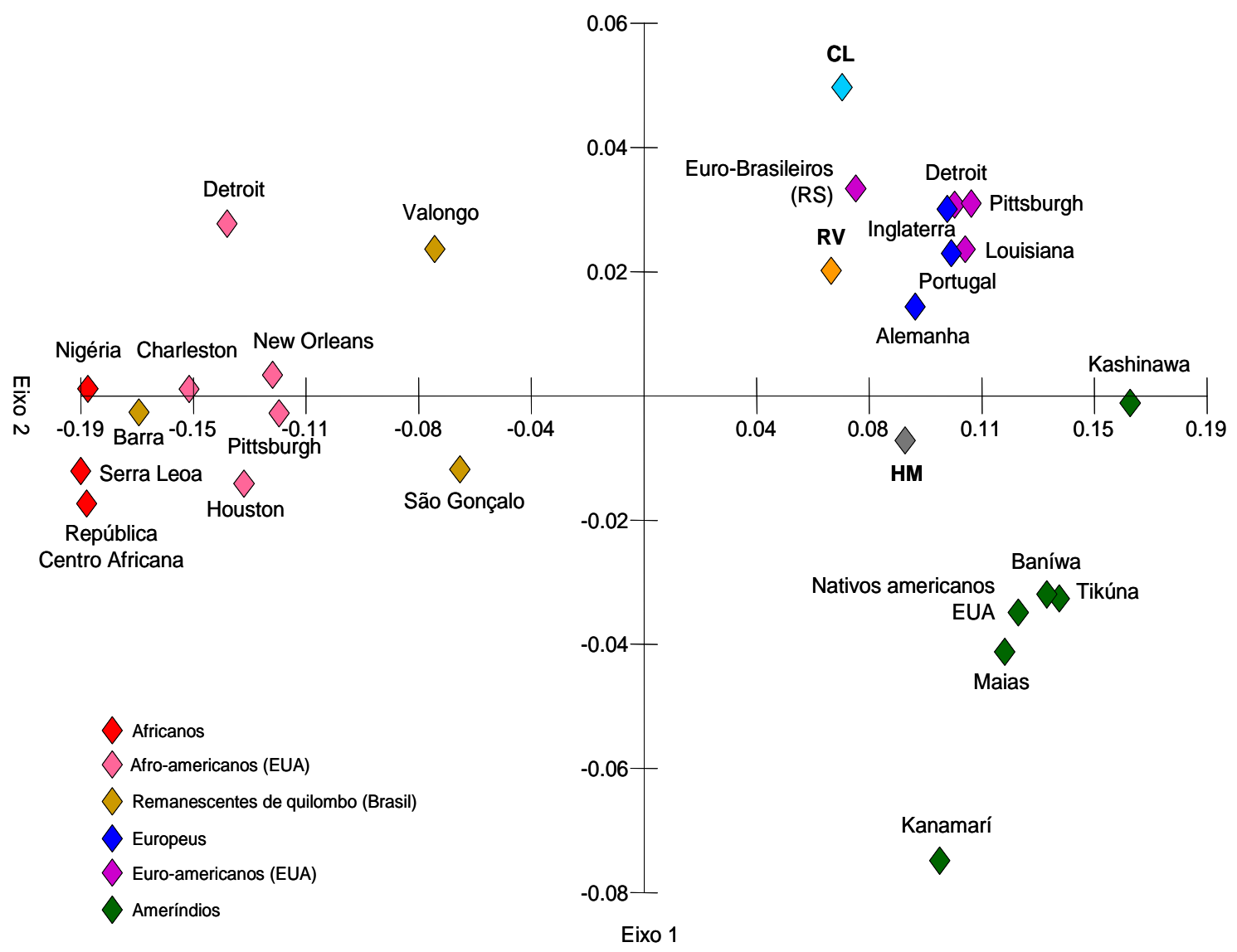

Figura 12: Componentes principais obtidos a partir de seis AIMs (FY, RB, LPL, AT3, Sb19.3 e APO) que relacionam as freqüências alélicas das populações analisadas com populações mundiais. Populações africanas e européias (PARRA et al., 2001; TOMÁS et al., 2002), afro- e euro-americanas (PARRA et al., 1998), euro-brasileiros (ZEMBRZUSKI et al., 2006), e populações indígenas da América do Norte (dbSNP, PSU-ANTH) e da Amazônia Brasileira (LUIZON et al., 2008a).

As populações de CL e RV estão agrupadas com as populações européias e euroamericanas. A amostra urbana do HM encontra-se próxima a este agrupamento, mas em direção ao agrupamento das populações ameríndias (Figura 12).

Tabela 18: Características dos componentes principais baseados nas freqüências alélicas de seis AIMs (FY, RB, LPL, AT3, Sb19.3 e APO).

\begin{tabular}{cccc}
\hline \hline Componente & Eigenvalue & $\begin{array}{c}\text { Proporção } \\
\text { explicada (\%) }\end{array}$ & $\begin{array}{c}\text { Proporção cumulativa } \\
\text { explicada (\%) }\end{array}$ \\
\hline \hline Eixo 1 & 0,447 & 91,674 & 91,674 \\
Eixo 2 & 0,022 & 4,424 & 96,098 \\
\hline \hline
\end{tabular}


Tabela 19: Pesos (loadings) das variáveis na resolução dos componentes principais na análise baseada em seis AIMs (FY, RB, LPL, AT3, Sb19.3 e APO).

\begin{tabular}{|c|c|c|}
\hline & Eixo 1 & Eixo 2 \\
\hline$\overline{F Y}$ & $\overline{0,608}$ & 0,109 \\
\hline RB & $-0,439$ & 0,132 \\
\hline LPL & $-0,314$ & $-0,093$ \\
\hline AT3 & $-0,430$ & 0,544 \\
\hline Sb19.3 & 0,229 & 0,815 \\
\hline APO & 0,320 & 0,032 \\
\hline
\end{tabular}

As freqüências do locus PV92 não estão disponíveis em todas as populações acima. No entanto, devido à importância deste AIM na separação entre ameríndios e europeus, uma análise separada foi realizada incluindo este marcador (Figura 13 e Tabelas 20 e 21). O alelo CYP1A1*2C não foi incluído nesta análise, pois suas freqüências não estão disponíveis nas populações comparadas.

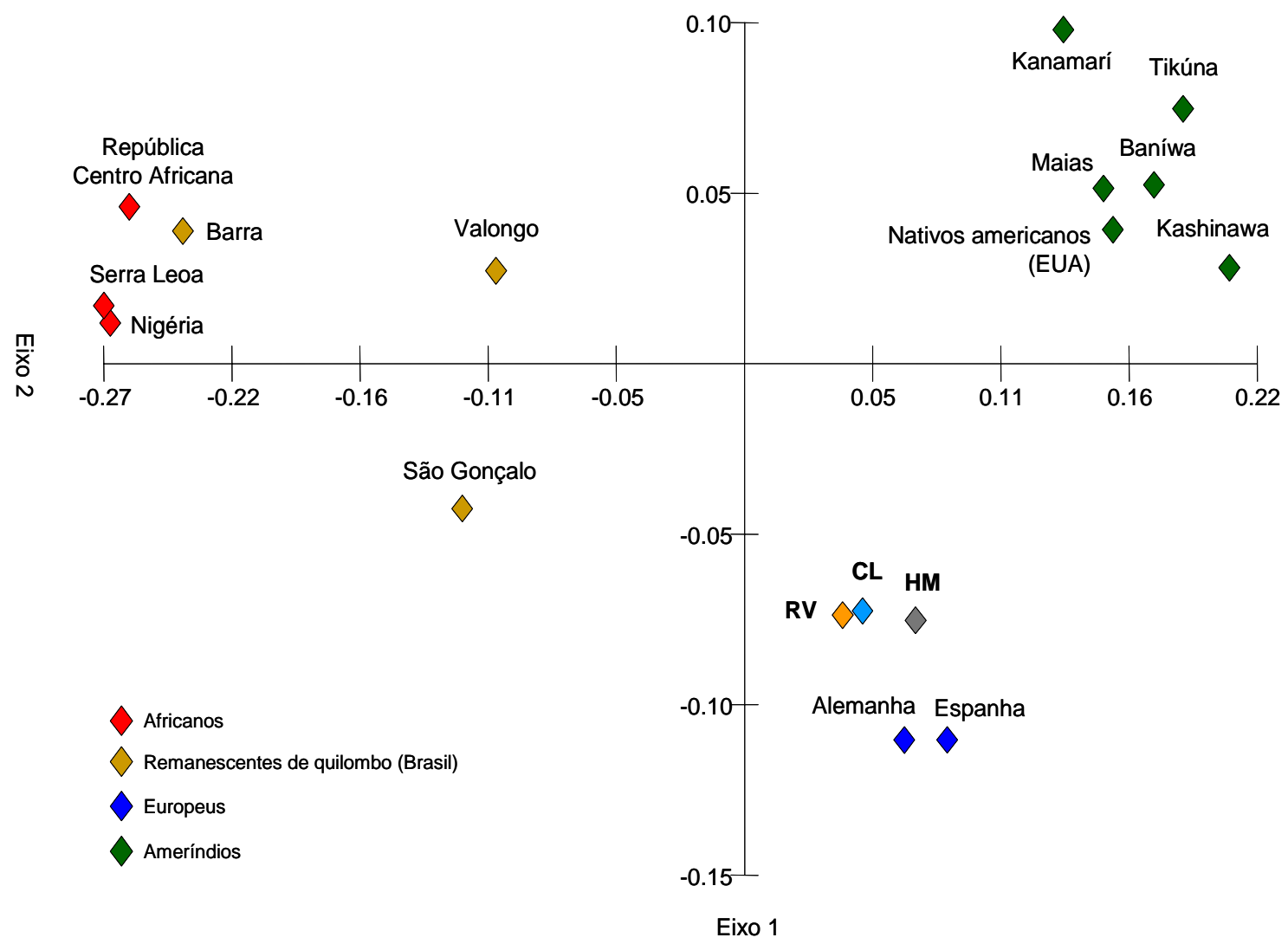

Figura 13: Componentes principais obtidos a partir da adição do locus PV92 aos seis AIMs da Figura 2, que relacionam as freqüências alélicas das populações analisadas com populações mundiais. Populações africanas e européias (PARRA et al., 2001; TOMÁS et al., 2002), afro- e euro-americanas (PARRA et al., 1998), euro-brasileiros (ZEMBRZUSKI et al., 2006), e populações indígenas da América do Norte (dbSNP, PSU-ANTH) e da Amazônia Brasileira (LUIZON et al., 2008a). 
Tabela 20. Características dos componentes principais baseados nas freqüências alélicas de sete AIMs (FY, RB, LPL, AT3, Sb19.3, APO e PV92).

\begin{tabular}{cccr}
\hline \hline Componente & Eigenvalue & $\begin{array}{c}\text { Proporção } \\
\text { explicada (\%) }\end{array}$ & $\begin{array}{c}\text { Proporção cumulativa } \\
\text { explicada (\%) }\end{array}$ \\
\hline \hline Eixo 1 & 0,500 & 82,482 & 82,482 \\
Eixo 2 & 0,070 & 11,592 & 94,073 \\
\hline \hline
\end{tabular}

Tabela 21: Pesos (loadings) das variáveis na resolução dos componentes principais na análise baseada em sete AIMs (FY, RB, LPL, AT3, Sb19.3, APO e PV92).

\begin{tabular}{|c|c|c|}
\hline & Eixo 1 & Eixo 2 \\
\hline$\overline{F Y}$ & 0,562 & -0,291 \\
\hline RB & $-0,438$ & $-0,031$ \\
\hline LPL & - 0,292 & 0,059 \\
\hline AT3 & $-0,451$ & $-0,081$ \\
\hline Sb19.3 & 0,192 & - 0,427 \\
\hline APO & 0,301 & $-0,069$ \\
\hline PV92 & 0,276 & 0,847 \\
\hline
\end{tabular}

As populações ameríndias e européias encontram-se separadas (Figura 13) dado o alto diferencial de freqüência do AIM PV92 entre estes dois grupos étnicos (SHRIVER et al., 2003). Isto se reflete no peso $(0,847)$ deste locus na resolução do segundo componente principal (Tabela 20). As comunidades de CL e RV e a amostra urbana do HM estão agrupadas com as populações européias.

Os dois componentes principais explicaram mais do que 95\% da variância total somente na primeira análise (Tabelas 18). O locus FY apresenta o peso mais importante na resolução do primeiro componente em ambas as análises de componentes principais (Tabelas 19 e 21$)$

As análises obtidas a partir do haplótipo estendido do cromossomo Y encontram-se na Figura 14 e na Tabela 22.

As populações de CL e RV estão separadas de todas as demais populações utilizadas na comparação. A amostra urbana $(\mathrm{HM})$ encontra-se próxima à $\mathrm{SP}$, e ambas próximas às européias (Figura 14). 


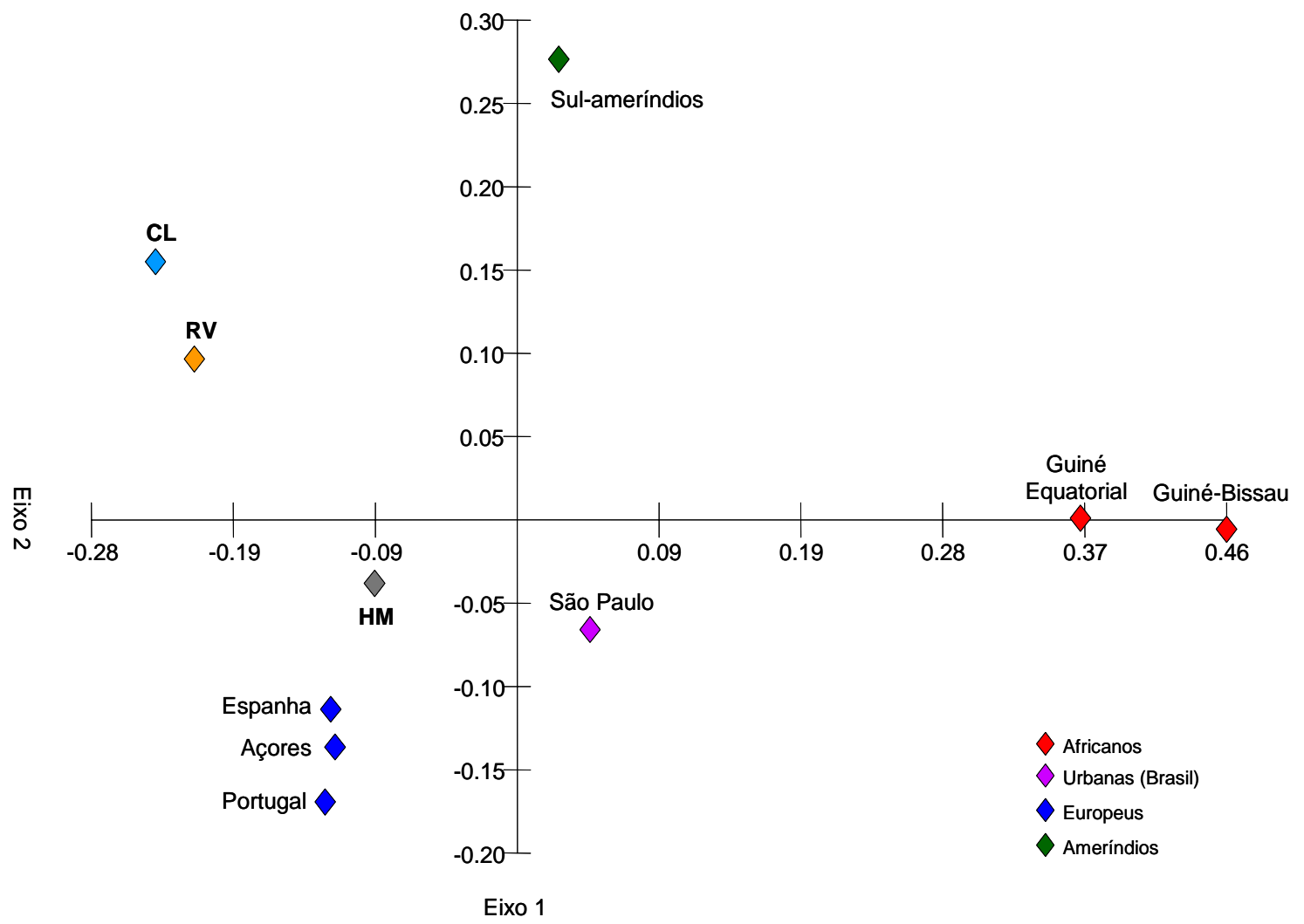

Figura 14: Componentes principais obtidos a partir do haplótipo estendido do cromossomo Y, que relacionam as freqüências alélicas das populações analisadas com populações mundiais: açorianos (FERNANDES \& BREHM, 2003 e ROSA et al., 2005), africanos (ARROYO-PARDO et al., 2005) e ameríndios (LEITE et al., 2008).

Tabela 22. Características dos componentes principais obtidos a partir do haplótipo estendido do cromossomo Y.

\begin{tabular}{l|rrrrrr}
\hline \hline & Eixo 1 & Eixo 2 & Eixo 3 & Eixo 4 & Eixo 5 & Eixo 6 \\
\hline \hline Eigenvalues & 0,508 & 0,176 & 0,147 & 0,056 & 0,038 & 0,025 \\
Proporção explicada (\%) & 51,240 & 17,734 & 14,794 & 5,654 & 3,851 & 2,526 \\
Proporção cumulativa explicada (\%) & 51,240 & 68,974 & 83,768 & 89,423 & 93,273 & 95,799 \\
\hline \hline
\end{tabular}

As freqüências dos loci que compõem o haplótipo estendido do cromossomo Y não estão disponíveis em todas as populações acima. Portanto, as análises de componente principal também foram realizadas a partir do haplótipo mínimo do cromossomo Y (Figura 15 e Tabela 23), o que permitiu a comparação com um maior número de populações urbanas brasileiras. 


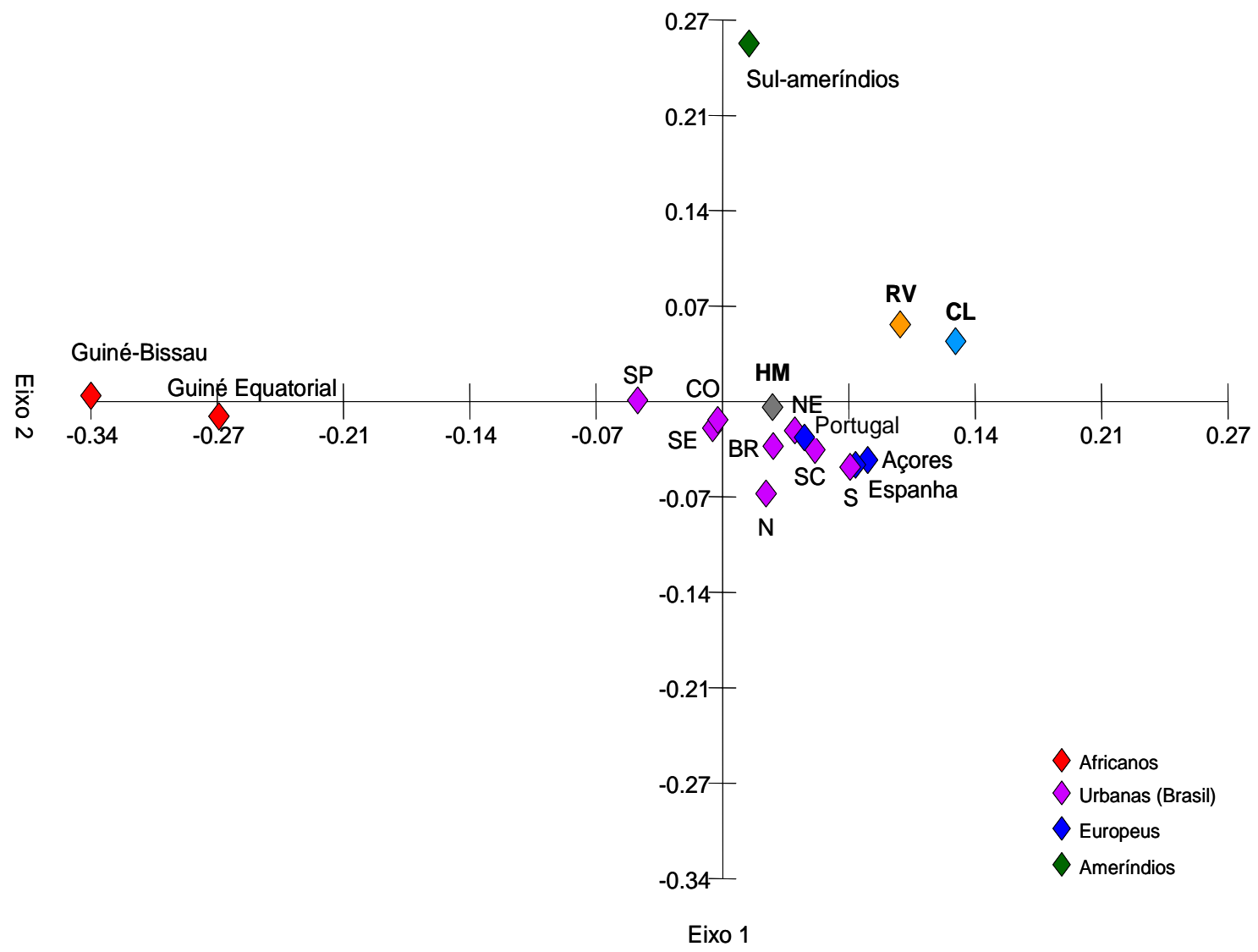

Figura 15: Componentes principais obtidos a partir do haplótipo mínimo do cromossomo Y, que relacionam as freqüências alélicas das populações analisadas com populações mundiais (açorianos, FERNANDES \& BREHM, 2003; portugueses, PONTES et al., 2007; e espanhóis, MARTíN et al. 2004; africanos, ARROYO-PARDO et al., 2005 e ROSA et al., 2005, e ameríndios, LEITE et al., 2008) e urbanas brasileiras das cinco regiões (N, CO, SE, NE e S, GRATTAPAGLIA et al., 2005), de São Paulo (SP, GÓES et al., 2008) e de Santa Catarina (SC, CAÍNÉ et al., 2005).

Tabela 23. Características dos componentes principais obtidos a partir do haplótipo estendido do cromossomo $\mathrm{Y}$.

\begin{tabular}{lrrrrrr}
\hline \hline & Eixo 1 & Eixo 2 & Eixo 3 & Eixo 4 & Eixo 5 & Eixo 6 \\
\hline \hline Eigenvalues & 0,243 & 0,085 & 0,054 & 0,028 & 0,017 & 0,014 \\
Proporção explicada (\%) & 50,171 & 17,588 & 11,230 & 5,813 & 3,457 & 2,860 \\
Proporção cumulativa explicada (\%) & 50,171 & 67,759 & 78,989 & 84,802 & 88,259 & 91,120 \\
\hline \hline
\end{tabular}

Todas as populações urbanas brasileiras comparadas encontram-se próximas nas análises da Figura 15.

Entretanto, é importante ressaltar que em ambas as análises obtidas a partir dos haplótipos de cromossomo Y (Figuras 14 e 15) foi necessário mais do que dois eixos (componentes principais) para explicar aproximadamente 95\% da variância total (Tabelas 22 e 23). 


\section{ESTIMATIVAS DE MISTURA ÉTNICA}

Tabela 24: Estimativa de mistura étnica nas comunidades analisadas considerando os dois grupos de marcadores analisados (AIMS e Haplótipo estendido do Y) e as estimativas já publicadas com marcadores clássicos e HLA nas comunidades estudadas (CL e RV) e população urbanas (HM).

\begin{tabular}{|c|c|c|c|c|c|c|c|}
\hline & Loci analisados & Europeus & Africanos & Ameríndios & Método & $\begin{array}{l}\mathrm{R}^{2} \text { ou } \\
\mathrm{MSE}\end{array}$ & Ref. \\
\hline \multirow{6}{*}{$\vec{u}$} & Marcadores Clássicos & $75,0 \pm 10,7$ & $17,3 \pm 8,9$ & $7,7 \pm 8,7$ & (2) & 3,3 & 3 \\
\hline & HLA & $77,6 \pm 9,2$ & $21,8 \pm 9,2$ & $0,6 \pm 1,1$ & (2) & 1,8 & 2 \\
\hline & STRs Autossômicos & $93,5 \pm 5,9$ & $4,1 \pm 3,9$ & $2,4 \pm 2,9$ & (1) & 99,8 & 1 \\
\hline & AlMs & $84,7 \pm 3,4$ & $13,3 \pm 1,4$ & $2,0 \pm 2,5$ & (1) & 99,8 & PE \\
\hline & Y-STRs + YAP & $95,6 \pm 10,6$ & $4,6 \pm 10,6$ & 0 & (1) & 94,2 & 1 \\
\hline & Hp estendido do $Y$ & $63,5 \pm 4,6$ & $18,1 \pm 2,7$ & $18,4 \pm 5,8$ & (1) & 96,2 & $\mathrm{PE}$ \\
\hline \multirow{6}{*}{$\vec{\nwarrow}$} & Marcadores Clássicos & $56,6 \pm 9,4$ & $27,3 \pm 10,6$ & $16,1 \pm 6,6$ & (2) & 1,6 & 2 \\
\hline & HLA & $79,2 \pm 6,8$ & $11,9 \pm 6,5$ & $9,0 \pm 2,9$ & (2) & 1,3 & 3 \\
\hline & STRs Autossômicos & $80,6 \pm 4,8$ & $12,6 \pm 1,1$ & $6,8 \pm 5,5$ & (1) & 99 & 1 \\
\hline & AIMs & $76,6 \pm 0,5$ & $16,9 \pm 0,2$ & $6,5 \pm 0,4$ & (1) & 99,9 & PE \\
\hline & Y-STRs + YAP & $94,1 \pm 6,2$ & $6,0 \pm 6,2$ & 0 & (1) & 97,8 & 1 \\
\hline & Hp estendido do $Y$ & $63,1 \pm 1,9$ & $21,9 \pm 0,8$ & $15,1 \pm 2,5$ & (1) & 99,3 & PE \\
\hline \multirow{2}{*}{$\sum_{\text {I }}$} & AlMs & $79,1 \pm 0,2$ & $14,7 \pm 0,1$ & $6,2 \pm 0,1$ & (1) & 99,9 & PE \\
\hline & Hp estendido do $Y$ & $63,0 \pm 1,9$ & $21,9 \pm 0,8$ & $15,1 \pm 2,5$ & (1) & 99,3 & PE \\
\hline
\end{tabular}

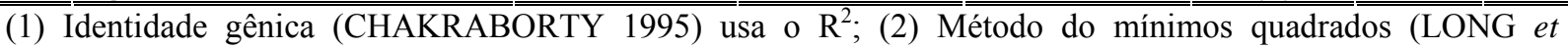
al.,1991) usa o MSE.

Referências: PE - Presente estudo; 1 - Muniz 2003, 2 - SOUZA et al. 2003 e 3 - SOUZA 2001.

As estimativas de mistura étnica apresentaram valores discordantes (Tabela 24) quando considerados separadamente os diferentes tipos de marcadores (HLA, STR autossômicos, clássicos, AIMs e ligados ao cromossomo Y) As estimativas calculadas no presente estudo foram consistentes com o modelo triíbrido e indicam uma contribuição européia preponderante, independente do marcador utilizado.

A CL apresentou uma maior contribuição européia (Portugueses ou Açorianos) em relação a RV, tanto nas estimativas com AIMs como nas do haplótipo estendido do cromossomo Y. A contribuição africana foi a segunda maior nas duas comunidades em ambos os conjuntos de marcadores, seguida da contribuição ameríndia, exceto em CL onde estas duas contribuições foram virtualmente idênticas (Tabela 24). 


\section{DISCUSSÃO}

\section{CROMOSSOMO Y. FREQÜÊNCIAS ALÉLICAS E DIVERSIDADE GENÉTICA}

As freqüências alélicas das duas comunidades são mais semelhantes às freqüências de portugueses e açorianos do que às de africanos e ameríndios, o que está de acordo com as estimativas de mistura (Tabela 6).

No locus DYS389I a presença dos alelos *11 e *15 e a ausência dos alelos *12 e *14 foram inesperadas. Os primeiros só foram descritos na amostra africana e os últimos estão presentes tanto na parental açoriana quanto no HM. Isto porque os alelos de origem africana nas comunidades (CL e RV) teriam tido origem na população negra da região, inclusive do centro urbano mais próximo de onde a amostra HM foi coletada.

Alguns alelos observados nas comunidades estudadas não foram descritos em nenhuma parental, tais como DYS392*16, DYS390*27, DYS438*13, presentes somente em RV, e DYS391*12, DSYS389I*11 e DYS438*14 nas duas comunidades. Este último também está presente na amostra urbana (HM) do presente estudo. A presença deles nas populações analisadas pode ser explicada por mutação ou mistura recente com populações não consideradas aqui.

\section{DIVERSIDADE HAPLOTÍPICA E AMOVA}

Um problema a ser considerado na discussão dos resultados da diversidade haplotípica foi o pequeno número de haplótipos completos nas amostras. Na CL, de um total de 44 homens somente 22 amplificaram todos os loci. Em RV são 50 homens e 32 haplótipos 
completos. E no HM uma redução ainda mais drástica, de 50 para 20. Essa diminuição amostral pode ter reduzido a diversidade dos haplótipos.

Comparando os haplótipos das amostras do presente estudo com amostras parentais e outras utilizadas na comparação foi possível verificar que o haplótipo 14/11,14/13/29/24/11/14/13/13/12 pertencente a RV foi amostrado uma vez na amostra Portugal. Com relação a amostra urbana HM o haplótipo 14/11,14/14/30/24/11/13/13/12/11 foi amostrado também uma vez em Portugal e São Paulo, e duas vezes na Espanha. O haplótipo 14/11,14/13/29/24/10/13/13/12/12 foi amostrado uma em Açores e São Paulo, quatro vezes em Portugal e cinco vezes na Espanha. E, por fim, o haplótipo 14/11,14/13/29/23/11/13/13/12/12 foi amostrado uma vez em Portugal e três na Espanha e em Açores.

A ausência de haplótipos compartilhados entre CL e outras populações pode ser explicada pela deriva genética, que teria reduzido a diversidade genética nesta população devido à perda aleatória de alelos.

A diversidade haplotípica ( $h$ ) foi estimada com fim comparativo, assim como para examinar a variação da diversidade genética intrapopulacional (SCHNEIDER et al., 2000) e apresentou altos valores em ambas as comunidades $(\mathrm{CL}=0,974$ e $\mathrm{RV}=0,998)$. Estes altos valores foram semelhantes aos previamente relatados em europeus $(0,985$; PRITCHARD et al., 1999), incluindo populações de Portugal (0,990; TROVOADA et al., 2001) e de Açores (0,976; CARVALHO et al., 2003 e 0,991; FERNADES \& BREHN, 2003).

Altos valores de diversidade haplotípica podem ser explicados pela alta taxa de mutação $\left(2,8 \times 10^{-3}\right.$ por geração) dos STRs-Y (KAYSER et al., 2000) e pela miscigenação restaurando a variabilidade genética nestas populações. Pode ser explicada também pela alta diversidade observada nas populações ancestrais. 
A análise de variância molecular (AMOVA) mostrou que quase toda diversidade haplotípica está dentro das comunidades $(94,24 \%)$.

Podemos concluir que, com relação ao cromossomo $\mathrm{Y}$, as duas comunidades ainda apresentam semelhanças considerando as análises de diferenciação gênica. Isto pode ser devido à origem comum e recente e à proximidade geográfica, o que torna possível um fluxo de homens entre as duas comunidades. Entretanto, o acréscimo no número de marcadores ligados ao cromossomo $\mathrm{Y}$ permitiu a diferenciação entre estas duas comunidades, como mostram os valores de $F_{S T}$ e de diferenciação haplotípica.

Assim, o haplótipo estendido do cromossomo $\mathrm{Y}$ é capaz de diferenciar estas comunidades de origem comum e recente, em contraste com os resultados obtidos por um número menor de STRs ligados ao cromossomo $\mathrm{Y}$ nestas mesmas comunidades (MUNIZ 2003), mas de acordo com dados da literatura (PEREZ-LEZAUN et al., 1997b e JOBLING \& TAYLOR-SMITH 1995).

\section{AIMS. FREQÜÊNCIAS ALÉLICAS E DIVERSIDADE GENÉTICA}

Dos oito AIMs aqui analisados, que apresentam altos diferenciais de freqüência alélica (ઈ) quando são comparados africanos, europeus e ameríndios, seis deles (FY, RB, LPL, AT3, Sb19.3, APO) apresentam freqüências semelhantes em ameríndios e populações européias, mas muito diferentes daquelas encontradas em populações africanas (PARRA et al., 1998). Os outros dois $(\mathrm{PV} 92$ e o alelo $C Y P 1 A 1 * 2 C)$ apresentam alta freqüência entre ameríndios, mas baixa nos outros dois grupos populacionais (SHRIVER et al., 2003; LUIZON et al., 2008b). O alelo CYP1A1*2C confirmou-se como um AIM capaz de distinguir os ameríndios 
dos outros grupos após a comparação das freqüências de quatro tribos indígenas da Amazônia Brasileira com dados da literatura (LUIZON et al., 2008b).

A média ponderada $(90,9 \%)$ das freqüências descritas por LUIZON et al., (2008b) é maior do que a das demais tribos $(73,2 \%)$ relatadas na literatura. As primeiras são provavelmente mais representativas, pois as tribos apresentam baixa mistura (2 a $3 \%$ ) com populações não-índígenas de acordo com marcadores clássicos (MOHRENWEISER et al., 1979, NEEL et al., 1980), do mtDNA, nos quais nenhum haplogrupo não indígena foi observado (MENDES-JUNIOR, 2005), e a partir da análise de AIMs (LUIZON et al., 2008a).

Os marcadores PV92 e CYP, capazes de diferenciar os indígenas dos grupos restantes, são particularmente importantes no estudo da composição triíbrida da população brasileira que, como nos informam os dados históricos, foi constituída pela união de contingentes de colonizadores europeus (principalmente portugueses), escravos africanos por eles trazidos e indígenas autóctones (RIBEIRO, 1995).

As freqüências do CYP1A1 em CL (2\%), RV (6\%) e HM (6,9\%) são concordantes com as freqüências européias (2,8 a 6\% - CASCORBI et al., 1996; LANDI et al., 2005). Estas poderiam ser explicadas pela preponderante contribuição deste grupo étnico na formação destas populações, como indicado por STRs autossômicos e ligados ao cromossomo Y (MUNIZ, 2003).

Quanto menor a população e quanto menos imigrantes receber, maior a tendência desta população à homozigose de seus loci em decorrência basicamente de dois processos: a ausência de migração - ou fluxo gênico - e o endocruzamento que, embora de natureza diferente, produzem o mesmo resultado, isto é, diminuem o número esperado de heterozigotos. 
Os valores de heterozigose $\left(H_{S}\right)$ observados em CL $(0,288 \pm 0,065)$ e HM $(0,294 \pm 0,053)$ são similares aos obtidos em populações Européias e Euro-americanas (Tabela 7). Por outro lado, RV apresentou diversidade maior $(0,341 \pm 0,048)$, indicativo de maior mistura com populações não européias, como previamente indicado pela análise de STRs autossômicos e do cromossomo Y nesta mesma população (MUNIZ, 2003).

\section{EQUILÍBRIO DE HARDY-WEINBERG}

Considerando-se as três populações analisadas foi possível realizar um total de 24 comparações entre as freqüências genotípicas observadas e esperadas (Tabela 13), das quais quatro resultaram em desvios significativos $(p<0,050)$. Destes, três $(\mathrm{HM} / \mathrm{AT} 3, \mathrm{CL} / \mathrm{APO}$ e RV/APO; Tabela 13) exibiram $p<0,002$, limite recalculado após a correção de Bonferroni $(0,050 / 24)$, e foram os únicos desvios considerados realmente significativos.

O caso de desvio significativo sem a correção de Bonferroni (RV/Sb19.3) deve ser, por força do teste, considerado como variação casual. Entretanto, a correção de Bonferroni é considerada uma medida conservadora, ou seja, modifica o limite de $\alpha$ para valores muito baixos, o que aumentaria a possibilidade de erros do tipo $\beta$, isto é, aumentaria a probabilidade de se aceitar o desvio como sendo casual quando deveria ser considerado significativo.

Devido ao isolamento e pequeno tamanho populacional da comunidade de CL, o desvio observado (locus APO) poderia ser explicado por casamentos não-aleatórios. Somado a isso, o número observado (3) de heterozigotos neste locus é seis vezes menor do que o esperado $(18,87)$ nesta população. 
Os desvios observados em RV e HM, por outro lado, poderiam ser explicados por fluxo gênico, como indicado pela história demográfica destas populações; quebra de isolado em RV (MUNIZ, 2003) e por HM pertencer a uma população exogâmica.

\section{DESEQUILÍBRIO DE LIGAÇÃO}

O fluxo gênico entre populações geneticamente distintas gera desequilíbrio de ligação (ALD) entre os loci (ligados e não ligados) que possuem freqüências alélicas diferentes (HARTL \& CLARK, 2007). Associações entre loci não ligados sugerem mistura recente, tão mais recente quanto maior o ALD.

Sete comparações (cinco em CL) resultaram em desvios significativos $(p<0,05$ : Tabela 13). Nenhum deles se manteve significativo após correção de Bonferroni.

Apesar disso, dado o conservadorismo da correção de Bonferroni, pode-se admitir que as cinco associações em CL seriam indicativas de eventos de mistura no momento da fundação desta comunidade ou ao longo de sua história de formação. As poucas associações significativas em RV e HM poderiam ser atribuídas ao acaso.

\section{DIFERENCIAÇÃO POPULACIONAL}

Quando são considerados os STRs de Y, a diferenciação entre duas populações é determinada pela deriva genética e pelas mutações (PÉREZ-LEZAUN et al., 1997b). O tamanho efetivo populacional estimado a partir de marcadores do cromossomo Y é apenas 1/4 do obtido a partir de marcadores autossômicos, o que resulta em menor diversidade e torna mais pronunciado o efeito da deriva genética (JOBLING \& TYLER-SMITH, 1995). 
Esta variação causada pelo processo de deriva poderia levar a divergência genética entre as populações. Em função disso, os STRs do cromossomo Y são considerados ideais na detecção de diferenças entre populações que tenham divergido recentemente (ROEWER et al., 1996 e PEREZ-LEZAUN et al., 1997b).

No entanto, esta diferenciação não foi observada entre as duas comunidades analisadas, pois os dez STRs ligados ao cromossomo Y analisados em conjunto não indicaram diferenciação entre as duas comunidades estudadas, apenas destas com a amostra urbana HM (Tabela 14). Isoladamente, apenas o locus DYS438 apresentou diferença significativa $(p=0,015)$ entre as comunidades de CL e RV, embora seis loci tenham diferenciado CL do $\operatorname{HM}(p<<0,001$ a $p=0,010)$ e quatro RV do HM $(p<<0,001$ a $p=0,028)$.

Os AIMs, contudo, mostraram situação oposta. Comparando par a par as três amostras pelo teste exato de Fisher, todas as freqüências alélicas e genotípicas apresentaram desvios significativos nas comparações RV/CL e CL/HM. Na comparação RV/HM, apenas as freqüências alélicas mostraram-se significativamente diferentes.

A conhecida história recente de formação das duas comunidades sugere que as diferenças entre elas seriam mais plausivelmente atribuídas ao fluxo gênico, o que seria confirmado pela conclusão de que a comunidade RV encontra-se em fase de quebra de isolado (SOUZA et al., 2003, MUNIZ 2003). Isto explicaria a diferenciação parcial (apenas com relação às freqüências alélicas) desta comunidade e a amostra urbana HM. 


\section{DIVERSIDADE INTERPOPULACIONAL (ESTATÍSTICAS F)}

\section{- Coeficiente de endogamia $\left(F_{I S}\right)$}

Diferente do esperado a amostra RV, que se encontra em fase de quebra de isolado, e a urbana $\mathrm{HM}$ apresentaram $F_{I S}$ significativo. Enquanto que $\mathrm{CL}$ apresentou $F_{I S}$ não significativo, apesar de apresentar isolamento geográfico e cultural em relação às comunidades vizinhas e um alto coeficiente de endogamia, calculado a partir de dados demográficos (MUNIZ et al., 1986; Tabela 15).

A comunidade de RV se apresenta em fase de quebra de isolado. Marcadores clássicos, STRs autossômicos (SOUZA et al., 2003), AIMs e STRs ligados ao cromossomo Y analisados neste estudo indicam que esta população é tri-híbrida (Tabela 24) e, portanto, tal parâmetro seria provavelmente decorrente da sub-estrutura populacional e não de endogamia. Tal explicação pode ser aplicada também ao valor de $F_{I S}$ significativo observado na amostra do HM, que foi retirada de uma população exogâmica caracterizada por mistura étnica recente.

\section{- Diversidade inter-populacional $\left(F_{S T}\right)$}

A maioria das populações são constituídas por sub-populações, dentro das quais ocorre geralmente a reprodução. Tal fato é denominado estrutura populacional ou subdivisão populacional (HARTL \& CLARK, 2007).

Este parâmetro calculado com base nos AIMS não diferenciou RV de HM (Tabela 16), concordando com a não diferenciação genotípica estimada pelas comparações par a par entre estas populações. 
O haplótipo estendido do cromossomo Y diferenciou todos os pares de populações analisados, incluindo as duas comunidades de origem comum e recente, CL e RV. Isto atesta o poder dos STRs ligados ao cromossomo Y nas análises de diferenciação populacional (ROEWER et al., 1996 e PEREZ-LEZAUN et al., 1997b ).

\section{AIMS. ESTRUTURA POPULACIONAL}

O software STRUCTURE utiliza um método de agrupamento, baseado no modelo desenvolvido por PRITCHARD et al. (2000), para a inferência de estrutura populacional utilizando dados genotípicos de marcadores não ligados. Por estrutura populacional entendese a presença de sub-populações de indivíduos geneticamente similares que diferem entre as mesmas.

Três clusters (Figura 10) foram designados a partir das freqüências genotípicas das populações analisadas. Pode-se observar que grande proporção $(0,996)$ da amostra de Africanos está representada no cluster 1 , assim como a amostra de Ameríndios $(0,789)$ está representada no cluster 2 e a amostra de Europeus $(0,562)$ no cluster 3.

É importante salientar que todos estes clusters, principalmente os de número 2 e 3 , possuem contribuição dos outros dois grupos reconhecidos como parentais. No cluster 2 pode-se observar uma proporção $(0,319)$ que refere-se ao componente europeu e no cluster 3 uma proporção $(0,148)$ que refere-se ao componente ameríndio.

Os clusters 2 e 3 têm informação "sobreposta", isto é, cada um deles apresenta contribuição característica do outro. Um maior número de AIMs informativos na separação destes dois clusters é necessária para que as proporções dos três clusters determinadas para cada população (Figura 10B) possa ser interpretada como contribuição dos componentes parentais para nas mesmas. 


\section{ANÁLISES DE COMPONENTE PRINCIPAL}

Os componentes principais são procedimentos utilizados na simplificação de dados multivariados com uma perda mínima de informação (CAVALLI-SFORZA et al., 1994). As populações do presente trabalho foram submetidas a esta análise em conjunto com populações mundiais no intuito de verificar eventual agrupamento por similaridade das freqüências dos alelos examinados. O maior número de populações disponíveis na literatura, considerando dados de AIMs, foi obtido considerando-se apenas seis (FY, RB, LPL, AT3, Sb19.3 e APO) destes loci, e está reproduzida na análise de componente principal da Figura 12.

Os loci CYP1A1 e PV92 diferenciam ameríndios dos outros dois grupos, africanos e europeus, mas apenas deste último encontram-se na literatura relatos de sua freqüência em número significativo de populações. A Figura 13 reproduz a análise do componente principal acrescentando-se o locus PV92, mas diminuindo-se o número de amostras populacionais.

Em ambas as análises (Figuras 12 e 13) as duas comunidades fundadas por açorianos (CL e RV) e a amostra urbana do HM agrupam-se com as populações européias, o que seria esperado pela preponderante contribuição deste componente nestas amostras.

As amostras ameríndias se agrupam isoladamente em ambas as situações. Na Figura 13 a amostra do HM aparece em direção ao agrupamento das populações ameríndias. Isto poderia indicar diferentes contribuições européia e ameríndia entre as populações aqui analisadas, ou ainda a baixa diferenciação das freqüências alélicas entre Europeus e Ameríndios pela bateria de AIMs escolhida. Entretanto, a amostra do HM apresenta uma preponderante contribuição do componente europeu (Tabela 24).

Com relação às análises de componente principal obtidas a partir dos haplótipos de cromossomo Y (Figuras 14 e 15 e Tabelas 22 e 23) é preciso ressaltar que 95\% da variância 
total não pode ser explicada por somente dois componentes principais (eixos). Isto quer dizer que maiores conclusões não podem ser extrapoladas a partir de tais resultados.

Entretanto, foi possível verificar (Figura 14 e 15) que as comunidades de CL e RV mantiveram-se sempre separadas e a amostra urbana (HM) sempre próxima às outras urbanas e européias. O agrupamento das populações urbanas nas análises obtidas a partir do haplótipo mínimo também merece destaque. Tal fato poderia indicar uma possível ausência de estruturação entre as populações urbanas brasileiras, previamente observado nestes marcadores (LEITE et al., 2008).

\section{ESTIMATIVAS DE MISTURA ÉTNICA}

Os resultados mostraram que CL e RV são amostras triíbridas (Tabela 24), o que está de acordo com estimativas prévias obtidas a partir de marcadores clássicos (SOUZA et al., 2003), loci de HLA (SOUZA, 2001) e STRs autossômicos (MUNIZ, 2003). As preponderantes contribuições européias em todas as amostras analisadas estão de acordo com estimativas prévias obtidas em populações da região Sul do Brasil, a partir dos AIMs (PARRA et al., 2003).

A contribuição africana na amostra do $\operatorname{HM}(14,7 \%)$ foi maior do que a observada em uma amostra Euro-derivada formada por indivíduos controles saudáveis do RS (6,5\%; ZEMBRZUSKI et al., 2006), também obtida pelo método de identidade gênica (CHAKRABORTY, 1985).

Alguns valores apresentam desvios-padrão maiores que as próprias estimativas (Tabela 24), o que se deve à problemas na escolha das populações ancestrais. 
A maior dificuldade da realização de cálculos de mistura étnica com haplótipo completo do cromossomo Y é a escassez da freqüência destes marcadores nas populações ancestrais (açorianos, populações africanas e populações indígenas brasileiras, principalmente do Sul do país). Dessa maneira, foram usadas apenas uma amostra de cada componente ancestral nesta análise. As porcentagens de contribuição de cada população ancestral estão na Tabela 24.

Com relação aos dados disponíveis para o haplótipo estendido do cromossomo Y, é importante ressaltar que as freqüências de ameríndios utilizados são oriundas das tribos Guarani e Kaingang do Sul do Brasil. As mesmas apresentariam um grau ainda indeterminado de mistura com não índios o que, por sua vez, causaria ruídos nas estimativas de mistura aqui apresentadas.

As freqüências africanas disponíveis são de uma amostra da população de GuinéBissau. Análises mais robustas necessitariam de amostras de outras nações africanas historicamente consideradas como fontes de indivíduos que foram trazidos ao Brasil.

Relatos históricos que indicam que a mistura entre os diferentes componentes étnicos ocorreu principalmente entre homens portugueses e mulheres ameríndias e/ou africanas explicariam a menor contribuição destes componentes nas comunidades semi-isoladas baseadas nos loci do cromossomo Y e nos loci autossômicos. Estudos anteriores (SOUZA, 20001; SOUZA et al., 2003; MUNIZ 2003) indicam esse desvio nas estimativas de mistura entre Y e autossômicos.

Os dados demográficos explicariam também o grande componente português estimado por marcadores herdados patrilinearmente. No entanto, a ação da deriva genética não pode ser descartada tendo em vista o reduzido tamanho efetivo das populações estudadas, sendo este 
ainda menor quando somente os loci do cromossomo Y são considerados (JOBLING \& TAYLOR-SMITH 1995; PEREZ-LEZAUN et al., 1997b).

A contribuição do componente ameríndio nas comunidades poderia ser explicada por mistura recente, tal como proposta por SOUZA (2001) que encontrou haplótipos de HLA (DRB1-DQA1) tipicamente ameríndios somente em indivíduos que vieram de fora das comunidades. Por outro lado, neste mesmo estudo, haplótipos tipicamente africanos foram encontrados em indivíduos nascidos na comunidade, indicando que a contribuição africana teria ocorrido desde a fundação destas comunidades.

A diferença nas estimativas de mistura étnica pode ser provavelmente explicada pelos diferentes tipos de herança e pelo número de marcadores utilizados. Outros problemas foram previamente descritos, tais como a determinação das populações ancestrais, diferenças dos períodos de chegada destas populações às comunidades sob estudo e o momento em que as populações são analisadas (SANS, 2000).

Como exposto acima, verificamos aqui que existe falta de informação sobre alguns grupos étnicos utilizados como parentais nas análises de mistura étnica. Principalmente sobre a exatidão de quais grupos africanos foram trazidos à região e a escassez de freqüências alélicas em populações ameríndias do Sul do país, as quais poderiam ter participado na formação das comunidades analisadas no presente estudo.

Os dados de mistura do presente estudo explicariam as diferenças nas freqüências alélicas entre CL e RV com Açores e algumas semelhanças com africanos ou ameríndios (Tabela 24).

Os dados de mistura descritos para estas comunidades (MUNIZ, 2003) indicam um cruzamento preferencial entre homens europeus e mulheres africanas e/ou ameríndias, 
mantendo assim o cromossomo Y tipicamente europeu nas duas comunidades. Estes dados sugerem que o fluxo gênico de homens entre as duas comunidades poderia estar atuando nesta homogeneização, hipótese corroborada pelo dados de diferenciação gênica obtidos a partir do Haplótipo estendido do cromossomo Y.

\section{CONSIDERAÇÕES FINAIS}

Considerando os marcadores ligados ao cromossomo Y, dados prévios (Muniz 2003) mostram que o cromossomo $\mathrm{Y}$ foi incapazes de separar as duas comunidades de origem recente e comum. Indicaram casamento preferencial entre homens portugueses e mulheres ameríndias e/ou africanas, pois os dados de mistura com esses marcadores indicam que a população masculina das comunidades é diíbrida e preponderantemente açoriana $(95,6$ na CL e 94,1\% em RV). Podemos concluir que as duas comunidades ainda se apresentam geneticamente semelhantes. Um fluxo de homens entre as duas comunidades favorecido pela proximidade geográfica, somado ao fato da origem comum e recente pode explicar a similaridade observada.

A ampliação do haplótipo do cromossomo $\mathrm{Y}$ neste estudo permitiu uma melhor diferenciação destas comunidades de origem comum e recente. A comparação com os dados prévios (MUNIZ, 2003) mostra que os dados de mistura étnica são contraditórios, pois indicam que as mesmas são triíbridas e com um componente açoriano menor $(63,5 \%$ e $63 \%$, respectivamente), mas aqui não se pode descartar os problemas com a análise e as parentais considerados anteriormente no tópico de mistura étnica.

Desta forma não podemos descartar a hipótese de cruzamento preferencial, que poderá ser confirmada com dados futuros de mtDNA. A análise do haplótipo estendido indicou uma diferenciação entre estas comunidades que são semelhantes quanto a origem e principalmente 
quando consideramos a população masculina. Mas é preciso melhorar o número de amostras com o haplótipo completo para maiores conclusões.

Com relação aos marcadores autossômicos, os AIMs aqui analisados foram capazes de diferenciar (Tabela 15) as comunidades de CL e RV, assim como outros marcadores autossômicos previamente descritos (SOUZA et al., 2003; MUNIZ, 2003).

Os valores de $F_{I S}$ para as comunidades foram inesperados. Entretanto, dados demográficos e genéticos previamente publicados (SALDANHA et al., 1996; ALVESJÚNIOR et al., 1998; SOUZA et al., 2003; MUNIZ 2003) mostram que CL ainda se constitui em um isolado genético, com uma grande probabilidade da deriva genética ser o fator evolutivo mais atuante na alteração das freqüências alélicas (SOUZA et al., 2003). Enquanto que em RV está ocorrendo uma quebra de isolado, e a migração seria o fator evolutivo preponderante (MUNIZ, 1999 e SOUZA et al., 2003).

As estimativas de mistura mostraram que as mesmas são trí́bridas, com preponderância do componente português. Além disso, o conjunto de AIMs utilizado foi capaz de indicar uma maior contribuição africana nas duas comunidades, quando comparados aos diferentes tipos de marcadores autossômicos (Tabela 24). É importante ressaltar também que as estimativas obtidas a partir dos AIMs apresentam menores desvios-padrão, o que confirma a eficiência destes marcadores para tal propósito (PARRA et al., 1998; BONILLA et al., 2005).

O ampliação de marcadores AIMs com alto diferencial de freqüência entre europeus e ameríndios será útil na melhor caracterização deste último componente no pool gênico autossômico destas comunidades. 


\section{CONCLUSÕES}

Conhecendo a história demográfica destas comunidades Costa da Lagoa (CL) e São João do Rio Vermelho (RV) e, com relação aos dados do presente estudo baseados em oito AIMs e 11 loci ligados ao cromossomo Y, concluímos que:

- Os alelos mais freqüentes dos AIMs e do cromossomo $\mathrm{Y}$ indicam uma maior semelhança com as populações européias e açorianas (no caso de Y-STRs).

- A diferenciação gênica par a par dos Y-STRs mostrou similaridade entre as comunidades, a qual pode ser explicada pela origem comum e recente.

- Os altos valores de diversidade haplotípica observados nas comunidades podem ser decorrentes da alta diversidade na população de origem (Açores), aliada à alta taxa de mutação atribuída aos microssatélites.

- A análise de variância molecular dos háplótipos do cromossomo Y indicou que a maior parte da variabilidade está dentro das populações. Entretanto, o acréscimo no número de marcadores ligados ao cromossomo Y permitiu a diferenciação entre estas duas comunidades, como mostram os valores de $F_{S T}$ e de diferenciação haplotípica.

- Os valores de $F_{S T}$ foram significativos tanto para os AIMs quanto para os Y-STRs. Estes indicam diferenciação entre as comunidades de CL e RV, e destas com a amostra urbana HM.

- Em ambas as análises de componente principal obtidas a partir dois AIMs, o locus FY foi a variável que maior peso ('loading’) demonstrou sobre o primeiro componente.

- A estimativa de mistura étnica obtida a partir dos Y-STRs indicou uma preponderante contribuição açoriana. Os AIMs indicam maior grau de mistura com 
populações africanas, o que seria explicado por cruzamentos preferenciais entre homens portugueses e mulheres ameríndias e/ou africanas.

Com relação ao cromossomo $\mathrm{Y}$, podemos concluir que as duas comunidades ainda apresentam semelhanças considerando as análises de diferenciação gênica. Isto pode ser devido à origem comum e recente e à proximidade geográfica, o que torna possível um fluxo de homens entre as duas comunidades. Entretanto, o acréscimo no número de marcadores ligados ao cromossomo $\mathrm{Y}$ permitiu a diferenciação entre estas duas comunidades, como mostram os valores de $F_{S T}$ e de diferenciação haplotípica.

As estimativas de mistura obtidas a partir do haplótipo estendido do cromossomo Y não são conclusivas devido à indisponibilidade de dados da literatura para uma escolha mais adequada das populações parentais.

Admitindo que os AIMs são marcadores mais eficientes em estimativas de mistura étnica, dado seus altos diferenciais de freqüência alélica entre populações parentais, as contribuições de populações não européias (principalmente africanas) observadas mantém a hipótese de cruzamentos preferenciais entre homens portugueses e mulheres ameríndias e/ou africanas pode como explicação mais plausível. 


\section{REFERÊNCIAS BIBLIOGRÁFICAS}

AGOSTINI, J. M. \& MEIRELLES-NASSER, C. M.. Consanguineous marriages in the archiocese of Florianópolis, South Brazil. Rev Brasil Genet. 11: 479-86. 1986.

ALVES, C.; GUSMÃO, L.; PEREIRA, L. \& AMORIM, A. STR data (CD4, CSF1PO, F13A01, FES/FPS, MBPB, TH01, TPOX) from North Portugal. Forensic Sci Int 123: 76772001 a.

ALVES-JÚNIOR, L.; SALDANHA, G. de M.; SUSIN M. F.; LIPINSKI, M. de S. \& SOUZA, I. R de. Dados demográficos e diversidade de sistemas sangüíneos eritrocitários nas comunidades da Costa da Lagoa e de São João do Rio Vermelho, Ilha de SC, Sul do Brasil. Biotemas 11(2): 121-32, 1998.

ARROYO-PARDO, E.; GUSMÃO, L.; LÓPEZ-PARRA, A. M.; BAEZA, C.; MESA, M. S.; AMORIM, A. Genetic variability of $16 \mathrm{Y}$-chromosome STRs in a sample from Equatorial Guinea (Central Africa). Forensic Sci Int. 149(1):109-13; Abr 20, 2005.

AYUB, Q., MOHYUDDIN, A., QAMAR, R., MAZHAR, K., ZERJAL, T., MEHDI, S. Q., TYLER-SMITH, C. Identification and characterisation of novel human Y-chromosomal microsatellites from sequence database information. Nucleic Acids Res. 28(2):e8. Jan 15, 2000 .

BATZER, M. A.; KILROY, G. E.; RICHARD, P. E.; SHAIKH, T. H.; DESSELLE, T. D.; HOPPENS, C. L. \& DEININGER, P. L. Structure and variability of recently inserted Alu family members. Nucleic Acids Res 18(23):6793-6798, 1990.

BECKMAN, J. S. \& WEBER, J. L. Survey of human and rat microsatellites. Genomics 12: 627-631, 1992.

BITTENCOURT, B. Avaliação do papel do endocruzamento no crescimento da comunidade isolada da Costa da Lagoa. 1993. Trabalho de Conclusão de Curso Centro de Ciências Biológicas, Universidade Federal de Santa Catarina, Florianópolis $\mathrm{SC}$.

BONILlA, C.; GUTIERREZ, G.; PARRA, E. J.; KLINE, C.; SHRIVER, M. D. Admixture analysis of a rural population of the state of Guerrero, Mexico. Am J Phys Anthropol 128:861-869, 2005.

BONILLA, C.; PARRA, E.J.; DIOS, S.; MARSHALL, J.A.; HAMMAN, R.F.; FERREL, R.E.; HOGGART, C.L.; McKEIGUE, P.M.; SHRIVER, M.D. Admixture in the Hispanics of the San Luis Valley, Colorado, and its implications for complex trait gene mapping. Ann Hum Genet. 68: 139-153, 2004.

BOITEAUX, H. Os municípios de Tijucas Grande e Porto Belo. Florianópolis: Livraria 
BUTlER, J. M.; SCHOSKE, R.; VALlONE, P. M.; KLINE, M. C.; REDD, A. J.; HAMMER, M. F. A novel multiplex for simultaneous amplification of $20 \mathrm{Y}$ chromosome STR markers. Forensic Sci Int. 10;129(1):10-24. Set 2002.

CAINÉ, L., CORTE-REAL, F., VIEIRA, D. N., CARVALHO, M., SERRA, A., LOPES, V., VIDE, M. C. Allele frequencies and haplotypes of 8 Y-chromosomal STRs in the Santa Catarina population of southern Brazil. Forensic Sci Int.;148(1):75-9. Fev 10, 2005

CASCORBI, I.; BROCKMOLLER, J.; ROOTS, I. A C4887A polymorphism in exon 7 of human CYP1A1: population frequency, mutation linkages, and impact on lung cancer susceptibility. Cancer Res 56(21):4965-9, 1996.

CARVALHO, M; ANJOS, M. J.; ANDRADE, L.; LOPES, V.; SANTOS, M. V.; GAMERO, J. J.; CORTE-REAL, F. \& VIDE, M. C. Y-chromosome STR haplotypes in two population samples: Azores Islands and Central Portugal. Forensic Sci Int 134(1):29-35, 2003.

CAVALLI-SFORZA, L. L.; MENOZZI, P. \& PIAZZA, A. History and geography of human genes. Princeton: Princeton University Press, 1994.

CHAKRABORTY, R. Gene identity in racial hybrids and estimation of admixture rates. In Ahuja YR, Neel JV, editors. Genetic diferentiation in human and others animal populations. Indian Anthropological Association. 1985. p. 171-180.

CHAMBERS, G. K. \& MACAVOY, E. S. Microsatellites: consensus and controversy. Comparative Biochemistry and Physiology Part B 126:445-476, 2000.

CHOUDHRY, S.; COYLE, N. E.; TANG, H.; SALARI, K.; LIND, D.; CLARK, S. L.; TSAI, H. J.; NAQ, VI, M.; PHONG, A.; UNG, N.; MATALLANA, H.; AVILA, P. C.; CASAL, J.; TORRES, A.; NAZARIO, S.; CASTRO, R.; BATTLE, N. C.; PEREZ-STABLE, E. J.; KWOK, P. Y.; SHEPPARD, D.; SHRIVER, M. D.; RODRIGUEZ-CINTRON, W.; RISCH, N.; ZIV, E.; BURCHARD, E. G. Genetics of Asthma in Latino Americans GALA Study. Population stratification confounds genetic association studies among Latinos. Hum Genet 118:652-664, 2006.

COLLINS, F. S.; BROOKS. L. D. \& CHAKRAVARTI, A. A DNA polymorphism discovery resource for research on human genetic variation. Genome Research 8:1229-1231, 1998.

CONRAD, R. Tumbeiros: o tráfico escravagista para o Brasil. Trad. Elvira Serapicos. São Paulo: Brasiliense, 1985.

FARIAS, V. F. Dos Açores para o Brasil Meridional: Uma viagem no tempo. Florianópolis: Do autor, 1998.

FERNANDES, A \& BREHM, A. Y-chromosome STR haplotypes in the Açores Archipelago (Portugal). Forensic Sci Int 135(3):239-42, 2003. 
FLORES, M. B. R. Povoadores da fronteira: os casais açorianos rumo ao sul do Brasil. Florianópolis: UFSC, 2000.

GIMENO, S. L. D. O destino viaja de barco: um estudo histórico, político e social da Costa da Lagoa e de seu processo de modernização. 1992. Dissertação de Mestrado, Universidade Federal de Santa Catarina, Florianópolis - SC.

GÓIS, C. C.; MARTINS, J. A.; PEREIRA, G. A.; FRESCHI, A.; PANETO, G. G.; ALVARENGA, V. L.; CICARELLI, R. M.; HIRATA, M. H.; OLIVEIRA, R. N. Genetic population data of 12 STR loci of the PowerPlex Y system in the state of São Paulo population (Southeast of Brazil). Forensic Sci Int. 174(1):81-6. Jan 15; 2008.

GOULART, A. Estudo genético demográfico de uma comunidade isolada na Ilha de Santa Catarina II São João do Rio Vermelho. 1986. Trabalho de Conclusão de Curso Centro de Ciências Biológicas, Universidade Federal de Santa Catarina, Florianópolis SC.

GUO, S. W.; THOMPSON, E. A. Performing the exact test of Hardy-Weinberg proportion for multiple alleles. Biometrics, 48(2):361-372, 1992.

GRATTAPAGLIA, D.; KALUPNIEK. S; GUIMARÃES. C. S.; RIBEIRO, M. A.; DIENER, P. S.; SOARES, C. N. Y-chromosome STR haplotype diversity in Brazilian populations. Forensic Sci Int. 149(1):99-107. Abr 20; 2005.

HARTL, D.L.; CLARK, A.G. Principles of population genetics. 4th ed. Sinauer Associates, Inc. Publishers. Sunderland, Massachusetts, 2007.

HIGUCHI, R. Simple and rapid preparation of samples for PCR. In: ERLICH, H. A., (Ed) PCR technology - principles and applications for DNA amplification. New York: Stockton, Press, 1989. p. 31-38.

IBGE - INSTITUTO BRASILEIRO DE GEOGRAFIA E ESTATÍSTICA. Censo demográfico 1991: Dados do Arquivo do Universo. Florianópolis: Gráfica do IBGE, 1992.

JOBLING, M. A. \& TYLER-SMITH, C. Fathers and sons: the Y chromosome and human evolution. Trends Genet 11: 449-456, 1995.

JORDE, L. B.; BANSHAD, M. J.; WATKINS, W. S.; ZENGER, R.; FRALEY, A. E.; KRAKOVIAK, P. A.; CARPENTER, K. D.; SOODYALL, H.; JEKINS, T. \& ROGERS, A. R. Origins and affinities of modern humans: a comparison of mitochondrial and nuclear genetic data. Am J Hum Genet 57:523-538, 1995.

KAN, Y. W. \& DOZY, A. M. Polymorphism of DNA sequence adjacent to the human $\beta$ globin structural gene. Its relation to the sickle mutation. Proc Natl Acad Sci USA 75: 5631-5638, 1978. 
KAYSER, M.; KNIJFF, P.; DIELTJES, P.; KRAWCZAK, M.; NAGY, M.; ZERJAL, T.; PANDYA, A.; TYLER-SMITH, C. \& ROEWER, L. Applications of microsatellite-based Y chromosome haplotyping. Electrophoresis 18: 1602-1607, 1997.

KAYSER, M.; ROEWER, L.; HEDMAN, M.; HENKE, L.; HENKE, J.; BRAUER, S.; KRÜGER, C.; KRAWCZAK, M.; NAGY, M.; DOBOSZ, T.; SZIBOR, R.; DE KNIJFF, P.; STONEKING, M. \& SAJANTILA, A. Characteristics and frequency of germline mutations at microsatellite loci from the human $\mathrm{Y}$ chromosome, as revealed by direct observation in father/son pairs. Am J Hum Genet 66:1580-1588, 2000.

KAYSER, M.; KRAWCZAK, M.;EXCOFFIER, L.; DIELTJES, P.; CORACH, D.; PASCALI, V.; GEHRIG, C.; BERNINI, L. F.; JESPERSEN, J.; BAKKER, E.; ROEWER, L. \& KNIFF P. An extensive analysis of Y-chromosomal microsatellite haplotypes in globally dispersed human populations. Am J Hum Genet 68:990-1018, 2001.

LANDI, M.T.; BERGEN, A.W.; BACCARELLI, A.; PATTERSON, D.G. JR, GRASSMAN, J.; TER-MINASSIAN, M.; MOCARELLI, P.; CAPORASO, N.; MASTEN, S.A.; PESATORI, A.C.; PITTMAN, G.S.; BELL, D.A. CYP1A1 and CYP1B1 genotypes, haplotypes, and TCDD-induced gene expression in subjects from Seveso, Italy. Toxicology 207(2):191-202, 2005.

LEITE, F. P.; CALlEGARI-JACQUES, S. M.; CARVAlHO, B. A.; KOMMERS, T.; MATTE, C. H.; RAIMANN, P. E.; SCHWENGBER, S. P.; SORTICA, V. A.; TSUNETO, L. T.; PETZL-ERLER, M. L.; SALZANO, F. M.; HUTZ, M. H. Y-STR analysis in Brazilian and South Amerindian populations. Am J Hum Biol. 2007 Dec 26;

LEWIS, P. O. \& ZAYKIN, D. Genetic data analysis: software for the analysis of discrete genetic data. Version 1.0. 1997.

LONG, J. C.; WILLIANS, R.C.; McAULEY, J. E.; MEDIS, R.; PARTEL, R.; TREGELLAS, M.; SOUTH, S. F.; REA, A. E.; McCORMICK, S. B. \& IWANIEC, U. Genetic variation in Arizona Mexican Americans: Estimation and interpretation of admixture proportions. Am J Phys Antropol 84: 141-157, 1991.

LUPI, J. \& LUPI, S. São João do Rio Vermelho dos Açores de Santa Catarina. Porto Alegre, Grafosul, 1989.

LUIZON, M. R.; MENDES-JUNIOR, C. T.; DE OLIVEIRA, S. F.; SIMOES, A. L. Ancestry informative markers in ameridians from Brazilian Amazon. Am J Hum Biol. 20(1):86-90. Jan-Fev;2008.

LUIZON, M. R.; SOUZA, I. R. De; SIMOES, A. L. CYP1A1*2C as an Ancestry Informative Marker (AIM) to detect Amerindian contribution in Brazilian populations. 2008b (no prelo). 
MARTINEZ-MARIGNAC, V. L.; VALLADARES, A.; CAMERON, E.; CHAN, A.; PERERA, A.; GLOBUS-GOLDBERG, R.; WACHER, N.; KUMATE, J.; MCKEIGUE, P.; O'DONNELL, D.; SHRIVER, M. D.; CRUZ, M.; PARRA, E. J. Admixture in Mexico City: implications for admixture mapping of type 2 diabetes genetic risk factors. Hum Genet. Feb;120(6):807-19, 2007.

MARTÍN, P.; GARCÍA-HIRSCHFELD, J.; GARCÍA, O.; GUSMÃO, L.; GARCÍA, P.; ALBARRÁN, C.; SANCHO, M.; ALONSO, A. A Spanish population study of $17 \mathrm{Y}$ chromosome STR loci. Forensic Sci Int 28;139(2-3):231-5. Jan 2004.

MENDES-JÚNIOR, C. T. Freqüências alélicas de polimorfismos de DNA do tipo STR em indígenas da Amazônia brasileira. 2001. Tese de Mestrado - Faculdade de Medicina de Ribeirão Preto, da Universidade de São Paulo, Ribeirão Preto - SP.

MOHRENWEISER, H.; NEEL, J. V.; MESTRINER, M. A.; SALZANO, F. M.; MIGLIAZZA, E.; SIMÕES, A. L.; YOSHIHARA, C. M. Electrophoretic variants in three Amerindian tribes: the Baníwa, Kanamari, and Central Pano of western Brazil. Am J Phys Anthropol, 50(2):237-46, 1979.

MOLLISON, P. L.. Blood transfusion in clinical medicine. 5.ed. Oxford: Blackwell, 1972.

MUNIZ, M. D.; AGOSTINI, J. M. S.; MUNIZ, E. C. N.; MEIRELLES-NASSER, C. M. \& FERRARI, N. Estudo demográfico e genético de uma comunidade isolada na Ilha de Santa Catarina, Brasil - Costa da Lagoa da Conceição. Ciênc Cult 38: 890, 1986.

MUNIZ, Y. C. N. Novos dados referentes as comunidades isoladas da Costa da Lagoa e de São João do Rio Vermelho - Sul do Brasil. 1999. Trabalho de Conclusão de Curso Centro de Ciências Biológicas, Universidade Federal de Santa Catarina, Florianópolis SC.

MUNIZ, Y. C. N. Comunidades semi-isoladas fundadas por açorianos na Ilha de Santa Catarina. 2003. Tese de Mestrado - Faculdade de Medicina de Ribeirão Preto, da Universidade de São Paulo, Ribeirão Preto - SP.

NAKAMURA, Y.; LEPPERT, M.; O'CONNELL, P.; WOLFF, R.; HOLM, T.; CULVER, M.; MARTIN, C.; FUJIMOTO, E.; HOFF, M.; KUMLIN, E. \& WHITE, R. Variable number of tandem repeat (VNTR) markers for human gene mapping. Science 235(4796):1616-22, 1987.

NAMEN, A. M. Botocudo: Uma história de contato. Florianópolis: UFSC/FURB, 1994.

NEI, M. Molecular evolutionary genetics. New York: Columbia University Press, 1987. $512 \mathrm{p}$.

OTA, T. DISPAN: genetic distance and phylogenetic analysis. Institute of Molecular Evolutionary Genetics, The University of Pennsylvania State University, University Park, PA, USA, 1993. 
PARRA, F. C.; AMADO, R. C.; LAMBERTUCCI, J. R.; ROCHA, J.; ANTUNES, C. M.; PENA, S. D. Color and genomic ancestry in Brazilians. Proc Natl Acad Sci U S A, 100(1):177-82, Jan 2003.

PARRA, E. J., KITTLES, R. A.; ARGYROPOUlOS, G.; PFAFF, C. L.; HIESTER, K.; BONILLA, C.; SYLVESTER, N.; PARRISH-GAUSE, D.; GARVEY, W. T.; JIN, L.; MCKEIGUE, P. M.; KAMBOH, M. I.; FERRELL, R. E.; POLliTZER, W. S. \& SHRIVER, M. D. Ancestral proportions and admixture dynamics in geographically defined African Americans living in South Carolina. Am J Phys Anthropol 114(1):1829. 2001.

PARRA, E. J.; MARCINI, A.; AKEY, J.; MARTINSON, J.; BATZER, M. A.; COOPER, R.; FORRESTER, T.; ALLISON, D. B.; DEKA, R.; FERRELL, R. E. \& SHRIVER, M. D. Estimating African American admixture proportions by use of population-specific alleles. Am J Hum Genet 63(6):1839-51, 1998.

PÉREZ-LEZAUN, A.; CALAFELL, F.; SEIELSTAD, M.; MATEU, E.; COMAS, D.; BOSCH, E. \& BERTRANPETIT, J Population genetics of Y-chromosome short tandem repeats in humans. J Mol Evol 45: 265-270, 1997a.

PÉREZ-LEZAUN, A.; CALAFELl, F.; MATEU, E.; COMAS, D.; BOSCH, E. \& BERTRANPETIT, J. Allele frequencies for 20 microsatellites in a worldwide population survey. Hum Hered 47: 189-196, 1997 b.

PFAFF, C. L.; PARRA, E. J.; BONILLA, C.; HIESTER, K.; McKEIGUE, P. M.; KAMBOH, M. I.; HUTCHINSON, R. G.; FERRELL, R. E.; BOERWINKLE, E.; SHRIVER, M. D. Population structure in admixed populations: effect of admixture dynamics on the pattern of linkage disequilibrium. Am J Hum Genet, 68:198-207, 2001.

PIAZZA, W. F. A colonização de Santa Catarina. Porto Alegre: BRDE, 1982.

PIAZZA, W. F. A escravidão negra numa província periférica. Florianópolis/Tubarão: Garapuvu e UNISUL, 1999.

PILlMAN, L. G. Aspectos ecológicos preliminares da comunidade de pescadores da Costa da Lagoa - Lagoa da Conceição, Ilha de Santa Catarina - SC. 1989. Trabalho de conclusão de Curso. - Centro de Ciências Biológicas, Universidade Federal de Santa Catarina. Florianópolis - SC.

PONTES, M. L.; CAINÉ, L.; ABRANTES, D.; LIMA, G.; PINHEIRO, M. F. Allele frequencies and population data for 17 Y-STR loci (AmpFISTR Y-filer) in a Northern Portuguese population sample. Forensic Sci Int. 20;170(1):62-7. Jul, 2007

PRITCHARD J. K.; STEPHENS M., DONNELLY P. Inference of population structure using multilocus genotype data. Genetics. 155(2):945-59. 2000. 
PRITCHARD, J. K.; SEIELSTAD, M. T.; PEREZ-LEZAUN, A.; FELDMAN, MW. Population growth of human Y chromosome: a study of $\mathrm{Y}$ chromosome microsatellites. Mol Biol Evol 16: 1791-1798, 1999.

QUINTANA-MURCI, L.; KRAUSZ, C. \& McELREAVEY, K. The human Y chromosome: function, evolution and disease. Forensic Sci Int 118:169-181. 2001.

RAYMOND, M. \& ROUSSET, F. GENEPOP (version 1.2): population genetics software for exact test and ecumenism. J Hered 86: 248-249, 1995a.

RAYMOND, M. \& ROUSSET, F. An exact test for population differentiation. Evolution 49: 1280-1283, $1995 \mathrm{~b}$.

RIBEIRO, D. O povo brasileriro: a formação e o sentido do Brasil. Companhia das Letras, São Paulo, 1995.

RODRIGUES, A. D. Línguas Brasileiras: para o conhecimento das línguas indígenas. São Paulo: Loyola, 1986.

ROEWER, L.; KAYSER, M.; DIELTJES, P., NAGY, M.; BAKKER, E.; KRAWCZAK, M. \& KNIJFF, P. Analysis of molecular variance (AMOVA) of Y-chromosome-specific microsatellites in two closely related human populations. Hum Mol Genet 5:1029-1033, 1996

ROSA, A.; ORNELAS, C.; BREHM, A.; VILLEMS, R. Population data on 11 Ychromosome STRs from Guiné-Bissau. Forensic Sci Int. 10;157(2-3):210-7. Mar, 2006.

ROSA, F. C. da. Identificação de proteínas plasmáticas nas comunidades da Costa da Lagoa e de São João do Rio Vermelho, Ilha de Santa Catarina, Sul do Brasil. 1997. Trabalho de Conclusão de Curso - Centro de Ciências Biológicas, Universidade Federal de Santa Catarina, Florianópolis - SC.

ROSA, F. C. da.; MAEGAWA, F. A. B. \& SOUZA, I. R. de. Identificação da variação em proteínas plasmáticas nas comunidades da Costa da Lagoa e de São João do Rio Vermelho, Ilha de SC, Sul do Brasil. Biotemas 11(1): 105-113, 1998.

SALDANHA, G. de M. Identificação da variabilidade dos sistemas sangüíneos eritrocitários ABO e RH nas comunidades da Costa da Lagoa e de São João do Rio Vermelho, na Ilha de Santa Catarina. 1996. Trabalho de Conclusão do Curso de Ciências Biológicas. Universidade Federal de Santa Catarina, Florianópolis - SC.

SALDANHA, G. de M.; ALVES-JÚNIOR, L.; SUSIM. M. F.; ROSA, F. C. da \& SOUZA, I. R. de. Dados demográficos e genéticos da comunidade isolada da Costa da Lagoa, Ilha de SC, sul do Brasil. Rev Brasil Genet 19: 242. 1996.

SALZANO, F. M. \& FREIRE-MAIA, N. Problems in human biology: a study of Brazilian populations. Detroit, Wayne State University Press, 1970. 
SANS, M. Admixture studies in latin America: from the 20th to the 21st century. Hum Biol 72:155-177, 2000.

SANTOS, S. C. Índios e brancos no sul do Brasil: a dramática experiência dos Xokleng. Florianópolis, Edeme, 1973.

SANTOS, S. C. Nova história de Santa Catarina. Florianópolis, Edição do Autor, 1974.

SANTOS, S. C. Nova história de Santa Catarina. Florianópolis, $4^{\mathrm{a}}$ ed. Ver. Forianópolis, Terceiro Milênio, 1998.

SALARI, K.; CHOUDHR, Y. S.; TANG, H.; NAQVI, M.; LIND, D.; AVILA, P. C.; COYLE, N. E.; UNG, N.; NAZARIO, S.; CASAL, J.; TORRES-PALACIOS, A.; CLARK, S.; PHONG, A.; GOMEZ, I.; MATALLANA, H.; PEREZ-STABLE, E. J.; SHRIVER, M. D.; KWOK, P. Y.; SHEPPARD, D.; RODRIGUEZ-CINTRON, W.; RISCH, N. J.; BURCHARD, E. G,; ZIV, E. Genetic admixture and asthma-related phenotypes in Mexican American and Puerto Rican asthmatics. Genet Epidemiol. 29(1):76-86, 2005.

SCHNEIDER, S.; ROESSLI, D. \& EXCOFFIER, L. Arlequin version 2000: a software for population genetics data analysis. Switzerland, Genetics and Biometry Laboratory, University of Geneva, 2000.

SCHUMM, J. W. Genetic identy; new aproaches to DNA fingerprint analysis. Promega Notes 58:12-20, 1996.

SHRIVER, M. D.; PARRA, E. J.; DIOS, S.; BONILLA, C.; NORTON, H.; JOVEL, C.; PFAFF, C. L.; JONES, C.; MASSAC, A.; CAMERON, N.; BARON, A.; JACKSON, T.; ARGYROPOULOS, G.; JIN, L.; HOGGART, C. J.; McKEIGUE, P. M.; KITTLES, R. A. Skin pigmentation, biogeographical ancestry and admixture mapping. Hum Genet,112(4):387-99, 2003.

SHRIVER, M. D.; SMITH, M. W.; JIN, L.; MARCINI, A.; AKEY, J. M.; DEKA, R.; FERRELL, R. E. Ethnic-affiliation estimation by use of population-specific DNA markers. Am J Hum Genet, 60:957-964, 1997.

SOUZA, I. R. de. Estudos demográficos, antropológico e genéticos das populações da Costa da Lagoa e de São João do Rio Vermelho, na ilha de Santa Catarina. 2001. Tese de doutorado. Universidade Federal do Paraná, Curitiba - PR.

SOUZA, I. R. de; MUNIZ, Y. C. N.; ALVES-JR, L.; SALDANHA, G. de M.; ROSA, F. C. da; MAEGAWA, F. A. B.; SUSIN, M. F.; LIPINSKI, M. de S. \& PETZL-ERLER, M. L.. Demographic and genetic structures of two partially isolated populations of Santa Catarina Island, Southern Brazil. Hum Biol 75(2):241-253, 2003.

TAVARES, L. H. D. Comércio proibido de escravos. São Paulo, Ática, 1988. 
TOMÁS, G.; SECO, L.; SEIXAS, S.; FAUSTINO, P.; LAVINHA, J.; ROCHA, J. The peopling of São Tomé (Gulf of Guinea): origins of slave settlers and admixture with the Portuguese. Hum Biol, 74(3):397-411, Jun 2002.

TROVOADA, M. J.; ALVES, C.; GUSMÃO, L.; ABADE, A.; AMORIM, A. \& PRATA, M. J. Evidence for population sub-structuring in São Tomé and Príncipe as inferred from Ychromosome STR analysis. Ann Hum Genet 65: 271-283, 2001.

WEIR, B. S.; COCKERHAM, C. C. Estimating F-statistics for the analysis of population structure. Evolution, 38(6):1358-1370, 1984.

WRIGTH, S. Evolution and genetics of populations. Vol. 2, Chicago University of Chicago Press, 1969.

ZEMBRZUSKI, V.M.; CALLEGARI-JACQUES, S.M.; HUTZ, M.H. Application of an African Ancestry Index as a genomic control approach in a Brazilian population. Ann Hum Genet. 70(Pt 6):822-8, 2006.

\section{Banco de dados em meio eletrônico:}

dbDNA Nuclear/gep-isfh In: GRUPO ESPANHOL E PORTUGUÊS DA ISFH. Disponível em: < http://www.ertzaintza.net/cgi-bin/db2www.exe/adn.d2w/WELCOME>. Acesso em: 25 out. 2003.

dbDNA-PCR Polymorphysms In: INSTITUTO DE MEDICINA FORENSE E INSTITUTO DE GENÉTICA HUMANA E ANTROPOLOGIA, HEINRICH - HEINE - UNIVERSITY, DÜSSELDORF, ALEMANHA. Disponível em: <http://www.uniduesseldorf.de/WWW/MedFak/Serology/dna.html>. Acesso em: 25 out. 2003.

dbSTR-DNA-Internet In: SHORT TANDEM REPEAT DNA INTERNET DATABASE/NIST. Disponível em: <http://www.cstl.nist.gov/biotech/strbase/> .Acesso em: 25 out. 2003.

Site Florianópolis In: GEOGRAFIA DA ILHA. Disponível em: $<$ http://florianopolis.virtualave.net/geografia.htm>. Acesso em: 25 out. 2003. 


\title{
MANUSCRITO PARA PUBLICAÇÃO
}

\section{Haplótipo estendido do cromossomo Y em Comunidades Fundadas por Açorianos na Ilha de Santa Catarina}

\author{
YARA C. N. MUNIZ1 ${ }^{1}$ MARCELO R. LUIZON² ${ }^{2}$ CELSO TEIXEIRA MENDES-JUNIOR ${ }^{3}$, \\ CLAUDIA E. V. WIEZEL ${ }^{1}$, AGUINALDO L. SIMÕES ${ }^{1}$ * \\ ${ }^{1}$ Departamento de Genética, Faculdade de Medicina de Ribeirão Preto, Universidade de São \\ Paulo, 14040-900 Ribeirão Preto, SP, Brazil \\ ${ }^{2}$ Departamento de Farmacologia, Faculdade de Medicina de Ribeirão Preto, Universidade de \\ São Paulo, 14040-900 Ribeirão Preto, SP, Brazil \\ ${ }^{3}$ Departamento de Clínica Médica, Faculdade de Medicina de Ribeirão Preto, Universidade de \\ São Paulo, 14040-900 Ribeirão Preto, SP, Brazil
}

\section{RESUMO}

Costa da Lagoa (CL) e São João do Rio Vermelho (RV) são comunidades fundadas no século XVIII por imigrantes Açorianos na Ilha de Santa Catarina, Sul do Brasil. As freqüências do haplótipo estendido do cromossomo $\mathrm{Y}$ foram determinadas nas comunidades de CL ( $n=20)$ e RV ( $n=32)$ no intuito de compará-las com as observadas nas populações parentais: açoriana, africana e ameríndia. Uma alta diversidade haplotípica foi observada em CL $(h=0,974), \operatorname{RV}(h=0,998)$ e HM $(h=1)$. As duas comunidades apresentam semelhanças considerando as análises de diferenciação gênica. Isto pode ser devido à origem comum e recente e à proximidade geográfica, o que torna possível um fluxo de homens entre as duas comunidades. Entretanto, o acréscimo no número de marcadores ligados ao cromossomo Y permitiu a diferenciação entre estas duas comunidades, como mostram os valores de $F_{S T}$ e de diferenciação haplotípica.

Palavras-chave: cromossomo Y, haplótipo estendido, comunidades semi-isoladas de origem açoriana.

\section{AGRADECIMENTOS}

Este trabalho foi realizado com suporte financeiro do Conselho Nacional de Desenvolvimento Científico e Tecnológico (CNPq).

*Correspondence to:

Aguinaldo Luiz Simões, Departamento de Genética FMRP, 14040-900 Ribeirão Preto, SP, Brazil.

E-mail: alsimoes@usp.br 


\section{INTRODUÇÃO \\ POPULAÇÕES:}

Homens saudáveis moradores das comunidades de Costa da Lagoa (CL; $n=20)$ e de São João do Rio Vermelho (RV; $n=32) \mathrm{CL}$, todos doadores voluntários que responderam a um questionário com informações demográficas que atestavam sua origem nas comunidades. Os procedimentos utilizados neste trabalho foram aprovados pelo Comitê de Ética e Pesquisa do Hospital das Clínicas (FMRP/USP), de acordo com o Processo HCRP nº 12665/2006.

\section{EXTRAÇÃO:}

As amostras foram extraídas de sangue total a partir do método de Higuchi (1989).

\section{PCR:}

Todos os loci (DYS19, DYS385a/b, DYS389I e II, DYS390, DYS391, DYS392 DYS393,

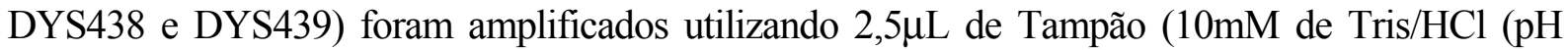

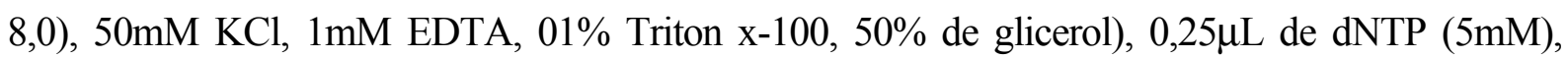
$1,0 \mu \mathrm{L}$ de $\mathrm{MgCL}_{2}(50 \mathrm{mM})$, e $0,4 \mu \mathrm{L}$ de Taq DNA Polimerase (1U/ $\left.\mu \mathrm{L}\right)$. Para os loci DYS19, DYS390, DYS391, DYS392 DYS393 foram utilizados 2,0 $\mu \mathrm{L}$ de primer, para os loci DYS385a/b,

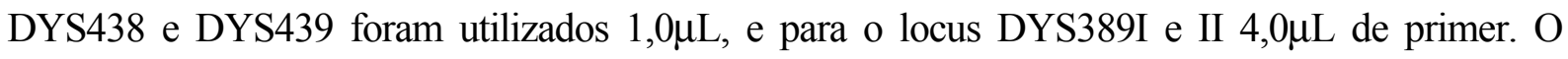
volume total da reação de $21 \mu \mathrm{L}$ foi completado com água. Os loci DYS385a/b e DYS439 foram amplificados na mesma reação, assim como os loci DYS389I e II e DYS438, e os demais amplificados individualmente. Em todas as reações foram utilizados $4,0 \mu \mathrm{L}$ de DNA genômico.

\section{ELETROFORESE:}

Os fragmentos de todos os loci foram separados por eletroforese em géis de poliacrilamida a $10 \%$, a $20 \mathrm{~mA}$ por gel. A coloração foi feita por nitrato de prata.

\section{ANÁLISE DOS DADOS:}

As freqüências alélicas e os valores de diversidade haplotípica foram obtidos com o uso do software Arlequin (http://anthropologie.unige.ch/arlequin). A heterogeneidade entre as populações foi testada pela comparação entre nossas amostras e dados da literatura. 
RESULTADOS:

Tabela 1: Descrição e Freqüência absoluta dos haplótipos estendidos nas comunidades de CL e RV.

\begin{tabular}{|c|c|c|c|c|c|c|c|c|c|c|c|c|}
\hline \multirow[b]{2}{*}{$\mathrm{N}^{\circ}$} & \multicolumn{10}{|c|}{ Número de repetições dos STRs } & \multicolumn{2}{|c|}{ Populações } \\
\hline & $\begin{array}{l}\text { DYS } \\
19\end{array}$ & $\begin{array}{l}\text { DYS } \\
\text { 385ab }\end{array}$ & $\begin{array}{l}\text { DYS } \\
3891\end{array}$ & $\begin{array}{l}\text { DYS } \\
38911\end{array}$ & $\begin{array}{l}\text { DY } \\
\text { S390 }\end{array}$ & $\begin{array}{l}\text { DYS } \\
391\end{array}$ & $\begin{array}{l}\text { DYS } \\
392\end{array}$ & $\begin{array}{l}\text { DYS } \\
393\end{array}$ & $\begin{array}{l}\text { DYS } \\
438\end{array}$ & $\begin{array}{l}\text { DYS } \\
439\end{array}$ & CL & RV \\
\hline 66. & 14 & 111,14 & 15 & 30 & 24 & 10 & 14 & 13 & 13 & 12 & 2 & \\
\hline 67. & 15 & 11,14 & 13 & 31 & 26 & 10 & 12 & 13 & 12 & 11 & 1 & \\
\hline 68. & 16 & 12,15 & 11 & 29 & 22 & 10 & 12 & 13 & 12 & 10 & 1 & \\
\hline 69. & 14 & 11,15 & 13 & 30 & 24 & 11 & 15 & 14 & 12 & 12 & 1 & \\
\hline 70. & 14 & 11,15 & 13 & 30 & 24 & 11 & 14 & 14 & 12 & 12 & 2 & \\
\hline 71. & 14 & 11,14 & 13 & 29 & 24 & 11 & 12 & 13 & 13 & 12 & 1 & \\
\hline 72. & 14 & 11,14 & 13 & 29 & 24 & 11 & 15 & 13 & 13 & 12 & 2 & \\
\hline 73. & 14 & 11,15 & 13 & 30 & 23 & 11 & 15 & 13 & 14 & 12 & 2 & \\
\hline 74. & 14 & 11,14 & 13 & 29 & 22 & 10 & 14 & 13 & 14 & 12 & 1 & \\
\hline 75. & 14 & 11,15 & 13 & 30 & 22 & 11 & 14 & 13 & 14 & 12 & 1 & \\
\hline 76. & 14 & 11,15 & 13 & 30 & 23 & 11 & 14 & 13 & 14 & 12 & 1 & \\
\hline 77. & 14 & 11,14 & 13 & 30 & 26 & 10 & 13 & 13 & 14 & 12 & 1 & \\
\hline 78. & 14 & 11,14 & 13 & 29 & 23 & 12 & 14 & 13 & 13 & 12 & 1 & \\
\hline 79. & 14 & 13,13 & 13 & 31 & 23 & 10 & 12 & 12 & 12 & 10 & 1 & \\
\hline 80. & 14 & 11,14 & 15 & 30 & 23 & 11 & 15 & 13 & 13 & 12 & & 1 \\
\hline 81. & 13 & 11,14 & 13 & 29 & 24 & 12 & 16 & 13 & 13 & 12 & & 1 \\
\hline 82. & 14 & 11,14 & 13 & 29 & 24 & 11 & 13 & 13 & 13 & 12 & & 1 \\
\hline 83. & 14 & 11,13 & 13 & 29 & 24 & 09 & 13 & 13 & 13 & 11 & & 1 \\
\hline 84. & 14 & 12,13 & 15 & 29 & 26 & 10 & 13 & 13 & 12 & 11 & & 1 \\
\hline 85. & 13 & 13,14 & 15 & 30 & 24 & 09 & 12 & 13 & 11 & 10 & & 1 \\
\hline 86. & 14 & 11,14 & 13 & 29 & 23 & 11 & 14 & 13 & 13 & 12 & & 1 \\
\hline 87. & 14 & 11,14 & 13 & 29 & 23 & 11 & 14 & 13 & 14 & 12 & & 1 \\
\hline 88. & 14 & 11,14 & 13 & 29 & 24 & 11 & 14 & 13 & 13 & 12 & & 1 \\
\hline 89. & 14 & 13,15 & 13 & 29 & 22 & 10 & 11 & 13 & 12 & 10 & & 1 \\
\hline 90. & 14 & 11,14 & 15 & 30 & 24 & 11 & 14 & 13 & 13 & 12 & & 1 \\
\hline 91. & 14 & 11,15 & 15 & 31 & 24 & 10 & 14 & 13 & 13 & 12 & & 1 \\
\hline 92. & 16 & 15,15 & 11 & 29 & 21 & 11 & 13 & 14 & 12 & 10 & & 2 \\
\hline 93. & 14 & 11,13 & 13 & 29 & 24 & 10 & 15 & 13 & 13 & 11 & & 1 \\
\hline 94. & 14 & 12,14 & 13 & 29 & 24 & 12 & 14 & 13 & 13 & 12 & & 1 \\
\hline 95. & 14 & 15,18 & 13 & 30 & 24 & 10 & 12 & 13 & 14 & 10 & & 1 \\
\hline 96. & 14 & 13,18 & 13 & 30 & 23 & 11 & 12 & 12 & 12 & 12 & & 1 \\
\hline 97. & 15 & 11,14 & 13 & 30 & 27 & 10 & 15 & 13 & 13 & 12 & & 1 \\
\hline 98. & 14 & 11,14 & 13 & 29 & 22 & 10 & 13 & 13 & 12 & 12 & & 1 \\
\hline 99. & 13 & 16,18 & 13 & 32 & 24 & 09 & 11 & 13 & 15 & 10 & & 1 \\
\hline 100. & 15 & 11,14 & 13 & 30 & 26 & 10 & 13 & 13 & 13 & 12 & & 1 \\
\hline 101. & 13 & 13,14 & 15 & 30 & 25 & 09 & 12 & 13 & 12 & 10 & & 1 \\
\hline 102. & 14 & 11,13 & 13 & 30 & 25 & 11 & 15 & 13 & 13 & 11 & & 1 \\
\hline 103. & 16 & 14,15 & 13 & 30 & 21 & 11 & 12 & 14 & 12 & 10 & & 1 \\
\hline 104. & 15 & 14,17 & 13 & 29 & 23 & 09 & 12 & 12 & 13 & 12 & & 1 \\
\hline 105. & 15 & 16,17 & 13 & 29 & 23 & 10 & 14 & 15 & 12 & 10 & & 1 \\
\hline 106. & 16 & 11,14 & 13 & 29 & 26 & 11 & 14 & 13 & 13 & 12 & & 1 \\
\hline 107. & 17 & 15,15 & 11 & 29 & 24 & 11 & 12 & 14 & 12 & 10 & & 1 \\
\hline 108. & 16 & 11,14 & 13 & 29 & 24 & 11 & 14 & 13 & 13 & 12 & & 1 \\
\hline 109. & 15 & 11,14 & 15 & 31 & 24 & 10 & 14 & 13 & 13 & 10 & & 1 \\
\hline 110. & 15 & 11,15 & 13 & 29 & 24 & 11 & 14 & 13 & 12 & 09 & & 1 \\
\hline $\mathrm{N}^{\circ} \mathrm{C}$ & omc & $\operatorname{mos}(n)$ & & & & & & & & & 22 & 32 \\
\hline Núm & & naplótipo & $(k)$ & & & & & & & & 14 & 31 \\
\hline Dive & rsidad & haplotípi & $a(h)$ & & & & & & & & 0.974 & 0,998 \\
\hline Erro & padrã & (SE) & & & & & & & & & 0.025 & 0,009 \\
\hline
\end{tabular}




\section{DISCUSSÃO:}

Comparando os haplótipos das amostras analisadas com os de amostras parentais foi possível verificar que o haplótipo 14/11,14/13/29/23/11/13/13/12/12 e o haplótipo 14/11,14/13/29/24/10/13/13/12/12 foram amostrados três e uma vezes em Açores, respectivamente.

A ausência de haplótipos compartilhados entre CL e outras populações pode ser explicada pela deriva genética, que teria reduzido sua diversidade genética devido à perda aleatória de alelos.

A diversidade haplotípica ( $h$ ) foi estimada com fim comparativo, assim como para examinar a variação da diversidade genética intrapopulacional (SCHNEIDER et al., 2000) e apresentou altos valores em ambas as comunidades $(\mathrm{CL}=0,974$ e $\mathrm{RV}=0,998)$. Estes altos valores foram semelhantes aos previamente relatados em europeus $(0,985$; PRITCHARD et al., 1999), incluindo populações de Portugal (0,990; TROVOADA et al., 2001) e de Açores (0,976; CARVALHO et al., 2003 e 0,991; FERNADES \& BREHN, 2003).

Altos valores de diversidade haplotípica podem ser explicados pela alta taxa de mutação $\left(2,8 \times 10^{-3}\right.$ por geração) dos STRs-Y (KAYSER et al., 2000) e pela miscigenação restaurando a variabilidade genética nestas populações. Pode ser explicada também pela alta diversidade observada nas populações ancestrais.

A análise de variância molecular (AMOVA) mostrou que quase toda diversidade haplotípica está dentro das comunidades $(94,24 \%)$.

Podemos concluir que as duas comunidades ainda apresentam semelhanças considerando as análises de diferenciação gênica. Isto pode ser devido à origem comum e recente e à proximidade geográfica, o que torna possível um fluxo de homens entre as duas comunidades. Entretanto, o acréscimo no número de marcadores ligados ao cromossomo Y permitiu a diferenciação entre estas duas comunidades, como mostram os valores de $F_{S T}$ e de diferenciação haplotípica.

Assim, o haplótipo estendido do cromossomo $\mathrm{Y}$ é capaz de diferenciar estas comunidades de origem comum e recente, em contraste com os resultados obtidos por um número menor de STRs ligados ao cromossomo Y nestas mesmas comunidades (MUNIZ 2003), mas de acordo com dados da literatura (PEREZ-LEZAUN et al., 1997b e JOBLING \& TAYLOR-SMITH 1995). 


\section{REFERÊNCIAS BIBLIOGRÁFICAS}

CARVALHO, M; ANJOS, M. J.; ANDRADE, L.; LOPES, V.; SANTOS, M. V.; GAMERO, J. J.; CORTE-REAL, F. \& VIDE, M. C. Y-chromosome STR haplotypes in two population samples: Azores Islands and Central Portugal. Forensic Sci Int 134(1):29-35, 2003.

FERNANDES, A \& BREHM, A. Y-chromosome STR haplotypes in the Açores Archipelago (Portugal). Forensic Sci Int 135(3):239-42, 2003.

JOBLING, M. A. \& TYLER-SMITH, C. Fathers and sons: the Y chromosome and human evolution. Trends Genet 11: 449-456, 1995.

KAYSER, M.; ROEWER, L.; HEDMAN, M.; HENKE, L.; HENKE, J.; BRAUER, S.; KRÜGER, C.; KRAWCZAK, M.; NAGY, M.; DOBOSZ, T.; SZIBOR, R.; DE KNIJFF, P.; STONEKING, M. \& SAJANTILA, A. Characteristics and frequency of germline mutations at microsatellite loci from the human $\mathrm{Y}$ chromosome, as revealed by direct observation in father/son pairs. Am J Hum Genet 66:1580-1588, 2000.

MUNIZ, Y. C. N. Comunidades semi-isoladas fundadas por açorianos na Ilha de Santa Catarina. 2003. Tese de Mestrado - Faculdade de Medicina de Ribeirão Preto, da Universidade de São Paulo, Ribeirão Preto - SP.

PÉREZ-LEZAUN, A.; CALAFELL, F.; MATEU, E.; COMAS, D.; BOSCH, E. \& BERTRANPETIT, J. Allele frequencies for 20 microsatellites in a worldwide population survey. Hum Hered 47: 189-196, $1997 \mathrm{~b}$.

PRITCHARD, J. K.; SEIELSTAD, M. T.; PEREZ-LEZAUN, A.; FELDMAN, MW. Population growth of human $\mathrm{Y}$ chromosome: a study of $\mathrm{Y}$ chromosome microsatellites. Mol Biol Evol 16: 1791-1798, 1999.

SCHNEIDER, S.; ROESSLI, D. \& EXCOFFIER, L. Arlequin version 2000: a software for population genetics data analysis. Switzerland, Genetics and Biometry Laboratory, University of Geneva, 2000.

TrovoAdA, M. J.; ALVES, C.; GUSMÃO, L.; ABADE, A.; AMORIM, A. \& PRATA, M. J. Evidence for population sub-structuring in São Tomé and Príncipe as inferred from Ychromosome STR analysis. Ann Hum Genet 65: 271-283, 2001. 